\title{
COMMUNITY RADIATION MONITORING PROGRAM
}

\author{
ANNUAL REPORT \\ October 1, 1992 - September 30, 1993 \\ by \\ E. Nathan Cooper
}

\section{DISCLAIMER}

This report was prepared as an account of work sponsored by an agency of the United States Government. Neither the United States Government nor any agency thereof, nor any of their employees, makes any warranty, express or implied, or assumes any legal liability or responsibility for the accuracy, completeness, or usefulness of any information, apparatus, product, or process disclosed, or represents that its use would not infringe privately owned rights. Reference herein to any specific commercial product, process, or service by trade name, trademark, manufacturer, or otherwise does not necessarily constitute or imply its endorsement, recommendation, or favoring by the United States Government or any agency thereof. The views and opinions of authors expressed herein do not necessarily state or reflect those of the United States Government or any agency thereof.

\section{RECEIVED \\ JAN 271995 \\ OS TI}

\section{August 1994}

\section{Publication \\ \# 45122}




\section{DISCLAIMER}

This report was prepared as an account of work sponsored by the United States Government. Neither the United States nor the United States Department of Energy, nor any of their employees, makes any warranty, express or implied, or assumes any legal liability or responsibility for the accuracy, completeness or usefulness of any information, apparatus, product or process disclosed, or represents that its use would not infringe privately owned rights. Reference herein to any specific commercial product, process, or service by trade name, mark, manufacturer, or otherwise, does not necessarily constitute or imply its endorsement, recommendation, or favoring by the United States Government or any agency thereof. The views and opinions of authors expressed herein do not necessarily state or reflect those of the United States Government or any agency thereof.

The report has been reproduced directly from the best available copy.

Available to DOE and DOE contractors from the Office of Scientific and Technical Information, P.O. Box 62, Oak Ridge, TN 37831; prices available from (615) 576-8401.

Available to the public from the National Technical Information Service, U.S. Department of Commerce, 5285 Port Royal Rd., Springfield, VA 22161. 


\section{DISCLAIMER}

Portions of this document may be illegible in electronic image products. Images are produced from the best available original document. 


\section{COMMUNITY RADIATION MONITORING PROGRAM ANNUAL REPORT}

October 1, 1992 - September 30, 1993

by

E. Nathan Cooper

Water Resources Center

Desert Research Institute

University and Community College System of Nevada

Publication \# 45122

prepared for

Nevada Operations Office

U.S. Department of Energy

Las Vegas, Nevada

August 1994

This document is UNCLASSIFIED

Derivative Classifier

Richard D. McArthur

Desert Research Institute

The work upon which this report is based was supported by the U.S. Department of Energy under Contract DE-AC08-90NV10845. 


\section{CONTENTS}

\section{SECTION}

1. INTRODUCTION 1

2. STATIONS AND STATION MANAGERS 3

General Comments 3

Manager Training 4

Manager Performance Evaluation $\quad 8$

3. PUBLIC INTERACTION 9

Outreach Efforts $\quad 9$

Site Visits 9

$\begin{array}{ll}\text { Communication } & 12\end{array}$

4. DATA VERIFICATION 13

$\begin{array}{ll}\text { 5. SUMMARY } & 14\end{array}$

$\begin{array}{ll}\text { REFERENCES } & 15\end{array}$

APPENDICES

A. Station Manager Training Sessions

B. Documentation of Outreach Efforts

C. Rocky Flats Plant Community Radiation (ComRad) Monitoring Program 


\section{SECTION 1}

\section{INTRODUCTION}

The Community Radiation Monitoring Program (CRMP) is a cooperative effort between the U. S. Department of Energy (DOE), the U. S. Environmental Protection Agency (EPA), the Desert Research Institute (DRI), a division of the University and Community College System of Nevada, and the Nuclear Engineering Laboratory of the University of Utah (UUNEL). The thirteenth year of this program began in the fall of 1992, and the work continues as an integral part of the DOE-sponsored long-term offsite radiological monitoring effort that has been conducted by EPA and its predecessors since the inception of nuclear testing at the Nevada Test Site (NTS).

This program began as an outgrowth of activities that occurred during the Three Mile Island incident in 1979. The local interest and public participation that took place there were thought to be transferable to the situation at the NTS, so, with adaptations, that methodology was implemented for this program. The CRMP began by enhancing and centralizing environmental monitoring and sampling equipment at 15 communities in the then-existing EPA monitoring network around the NTS, and has since expanded to 19 locations in Nevada, Utah, and California (see Figure 1).

The primary objectives of this program are still to increase the understanding by the people who live in the area surrounding the NTS of the activities for which DOE is responsible, to enhance the performance of radiological sampling and monitoring, and to inform all concerned of the results of these efforts. One of the primary methods used to improve the communication link with the people in the potentially impacted area has been the hiring and training of local citizens as Station Managers and program representatives in those selected communities in the offsite area. These managers, active science teachers wherever possible, have succeeded through their training, experience, community standing, and effort in becoming a very visible, able, and valuable asset in this link.

Other methods that are used to further the goals of the program include presenting public education forums in many communities, disseminating information on radiation, weapons testing, energy, and related subjects, plus developing and maintaining contacts with local citizens and elected officials in the offsite area. The public presentations have evolved from the original prescribed program into information on specific subjects being presented to identified and selected audiences who request information. These audiences include school classes at all levels, service clubs, professional groups, and conferences.

The responsibilities of the four entities involved in the program, documented in previous reports (see references), briefly are as follows: DOE provides funding and management guidance; EPA is responsible for all technical aspects of the program, i.e., equipment installation 
and maintenance, sample collection and analysis, data interpretation and dissemination, and management support; the UUNEL provides semi-annual technical training for Station Managers, Alternate Station Managers and others; and DRI organizes the public outreach component of the program, hires and manages Station Managers and Alternate Station Managers, assists with the training function, interacts with people in the offsite area, disseminates information as appropriate, and does limited data verification by duplication of certain sample collection and analysis functions.

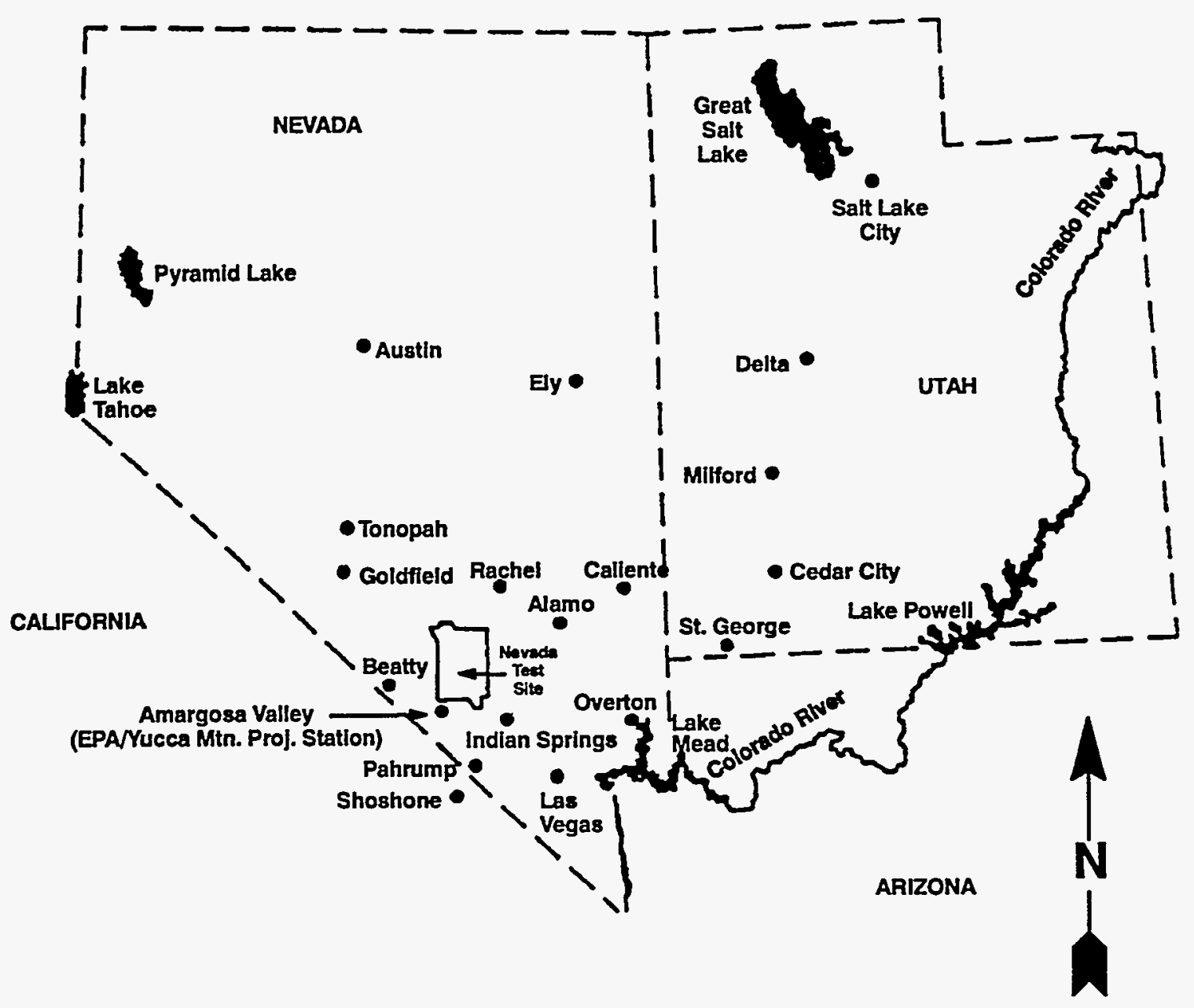

Figure 1. Community Radiation Monitoring Station Locations. 


\section{SECTION 2}

\section{STATIONS AND STATION MANAGERS}

\section{GENERAL COMMENTS}

The number and locations of the Community Radiation Monitoring Stations has remained constant since 1990 , when the Caliente station was added as our 19th location. Previously reported plans to establish two new stations and relocating several others are being held in abeyance, due to the testing moratorium and financial considerations.

Station Managers and Alternate Station Managers were in place at all 19 stations throughout the year, with no changes in the roster (see Table 1). Turnover remains remarkably low, with more than half (eight) of the people originally hired for the program in 1981 still involved. They continue to work as part-time professional employees of the DRI, with their annual contracts coinciding with the federal fiscal year.

\section{MANAGER TRAINING}

Two training sessions for Station Managers and Alternates were conducted by Dr. Gary Sandquist of the UUNEL during this year as has been done since the inception of the program. Agendas, attendance lists, and transcripts of pertinent portions of these events are included as Appendix A of this report.

For the first time since 1988 the Station Managers were given a tour of the NTS as a part of the Winter training session. The 1993 training was done on January 9-10, with the first day devoted to a full tour of the NTS, including Yucca Mountain. Some of the Managers and Alternates, being new to the program, had never been there, and the rest had not seen all of the things we were able to cover on this trip. The tour included the weapons effects test area, the Liquified Gaseous Fuel Spill Test Facility in Area 5, Control Point 1 for briefing films, Bilby and Sedan craters, the tunnel ponds in Area 12, and the Apple II houses remaining from atmospheric tests, all with excellent briefings from DOE staff. This was also the first time this group had been given the Yucca Mountain briefing and tour.

The training portion of this session was conducted at the DRI Southern Nevada Science Center in Las Vegas, with very appropriate presentations by Bruce Church of DOE, Barbara Fleming from the U. S. Council for Energy Awareness, Washington, D. C., and Gary Sandquist from UUNEL. The Sunday activities concluded with reports from each of the 27 Station Managers and Alternates who attended. Evaluations of the session ranged from good to great.

The Summer training session was held at the Brian Head Hotel in Brian Head, Utah, on August 2-6. Opening day events included presentations by Nick Aquilina, Manager of the Nevada Operations Office; Art Janata, Battelle Pacific Northwest Laboratories, Richland, 
Washington; Chris Brown, Citizens Alert, Las Vegas; Norma Cox, League of Women Voters, Las Vegas; Kyle Turner, American Nuclear Society; and Gary Sandquist. The cookout, done beautifully again by Fred Whicker of Cedar City High School, was held at Woods Ranch in Cedar Canyon.

After two days of intensive radiation/environmental training by Gary Sandquist, Mike Slaughter, and Bruce Hardy from the University of Utah and Daryl Thome' and staff of the EPA Environmental Monitoring Support Laboratory in Las Vegas, another two days of relevant topical presentations were made. Presenters of this material included Daryl Randerson, NOAA Weather Support Office; Ray Lloyd, Mike Slaughter, and Gary Sandquist, University of Utah; Anita Mullen and Daryl Thome' , EPA; and Asel Robison from the Yucca Mountain Project Office. Each of the 28 Station Managers and Alternates who attended then reported on activities, attitudes, and conditions in their communities. 
Table 1.

\section{COMMUNITY RADIATION MONITORING PROGRAM}

ALAMO

Clark M. "Rick" Hardy (Lorna)

P.O. Box 394

Alamo, NV 89001

(H) (702) $725-3442$

(W) (702) 725-3321

(Alternate)

Dell Sullivan (Marva)

P.O. Box 182

Alamo, NV 89001

(H) (702) 725-3544

AMARGOSA VALLEY

Kenneth G. Garey (Jean)

BBQ Ranch, Box 1

Amargosa Valley, NV 89020

(H) (702) 372-5254

AUSTIN

William S. (Bill) Cox (Loretta)

P.O. Box 286

Austin, NV 89310

(H) (702) 964-2385

(W) (702) 964-2467

(Alternate)

Thomas J. Brannan (Gail)

P.O. Box 59

Austin, NV 89310

(H) (702) 964-2631

(W) (702) 964-2108

\section{BEATTY}

John C. Lisle (Gennie)

P.O. Box 357

Beatty, NV 89003

(H) (702) 553-2326

(W) (702) 553-2595
(Alternate)

Richard A. Johnson (Nancy)

P.O. Box 626

Beatty, NV 89003

(H) (702) 553-2211

(W) (702) 553-2912 (Motel)

\section{CALIENTE}

Judy A. Foremaster (Lin)

P.O. Box 465

Caliente, NV 89008

(H) (702) 726-3766

(W) (702) 726-3690

\section{(Alternate)}

Brent H. Perkins (Tonya)

438 Mac Arthur Drive

Caliente, NV 89008

(H) (702) 726-3381

(W) (702) 726-3772

CEDAR CITY

Donald Newman (Ruth)

141 Sunbow

Cedar City, UT 84720

(H) (801) 586-2042

(W) (801) 586-2820

\section{(Alternate)}

Glade V. Sorensen (Sherie)

421 Circle Way Drive

Cedar City, UT 84720

(H) (801) 586-8372

\section{DELTA}

Thomas S. Judd (Sharon)

850 North 500 W.

Delta, UT 84624

(H) (801) 864-3779

(W) (801) 864-2745 
Table 1.

(Alternate)

Beverly Jean DeWyze (Jim)

P.O. Box 295

Delta, UT 84624

(H) (801) 864-2029

(W) (801) 864-3891

\section{$\underline{\text { ELY }}$}

Rebecca S. Murdock (Jesse)

207 E. Grant Ave.

Ely, NV 89301

(H) (702) 289-2729

(W) (702) 289-4841

(Alternate)

Gloria Ann Mullen

1325 Avenue C

Ely, NV 89301

(H) (702) 289-6540

(W) (702) 289-8800

GOLDFIELD

Myron A. Johnson (Bernice)

P.O. Box 166

Goldfield, NV 89013

(H) (702) 485-6360

(W) (702) 485-6355

(Alternate)

Christine D. Tatum (Tobie)

P.O. Box 558

Goldfield, NV 89013

(H) (702) 485-3224

(W) (702) 485-6337

\section{INDIAN SPRINGS}

James M. Hopkin (Lael)

P.O. Box 597

Indian Springs, NV 89018

(H) (702) 879-3232

(W) (702) 879-3201

(W) (No Charge) 382-8011
(Alternate)

Larry L. Hathhorn

P.O. Box 403

Indian Springs, NV 89018

(H) (702) 879-3823

(W) (702) 879-3201

\section{LAS VEGAS}

Don M. Curry (Jane)

2347 Capistrano

Las Vegas, NV 89109

(H) (702) 733-9573

(W) (702) 799-5164

(Alternate)

David J. Peltz

3323 Casey \#203

Las Vegas, NV 89120

(H) (702) 433-9941

(W) (702) 799-5164

\section{MILFORD}

Dale E. Jensen (Judy)

402 West 500 S., Box 25

Milford, UT 84751

(H) (801) 387-2656

(W) (801) 387-2751

\section{(Alternate)}

Morden Leon Gay (Carolee)

65 North 500 West

Milford, UT 84751

(H) (801) 387-2437

(W) (801) 387-2751

\section{OVERTON}

Nicklas J. Bowler (Bonnie)

P.O. Box 368

Logandale, NV 89021

(H) (702) 398-3596

(W) (702) 397-2611 
Table 1.

(Alternate)

Jack W. Nelson (Gaye)

P.O. Box 232

Logandale, NV 89021

(H) (702) 398-3503

(W) (702) 397-2611

PAHRUMP

Albert J. Giannotti (Maryann)

P.O. Box 145

Pahrump, NV 89041

(H) (702) 727-5386

(W) (702) 727-7737

\section{(Alternate)}

Daniel J. Donnelly (Joan)

HCR 77, Box 36803

Pahrump, NV 89041

(H) (702) 727-5188

(W) (702) 727-5546

\section{RACHEL}

Christy S. Castleton

Star Route, Box 39

Alamo, NV 89001

(H) (702) 729-2674

(W) (702) 729-2555

\section{(Alternate)}

Ruth Agee (Jace)

Star Route, Box 52

Alamo, NV 89001

(H) (702) 729-2620

\section{SALT LAKE CITY}

Gary M. Sandquist (Kristine)

2564 Neffs Circle

Salt Lake City, UT 84109

(H) (801) 273-0200

(W) (801) 581-7372 (UU)

(W) (801) 263-1600 (R\&A)

(W) (801) 581-6441 (UU)
ST. GEORGE

John F. (Jack) Heppler (Julie)

365 North Donlee Drive

St. George, UT 84770

(H) (801) 673-4556

(W) (801) 673-4811, ext 364

Secretary: ext 339

\section{(Alternate)}

Kelly N. Bringhurst (Brenda)

2402 E. 80 N. Circle

St. George, UT 84770

(H) (801) 628-4130

(W) (801) 673-4811, ext 401

\section{SHOSHONE}

Brian W. Brown (Bonnie)

P.O. Box 61

Shoshone, CA 92384

(H) (619) 852-4403

(W) (619) 852-4303, 4307

\section{(Alternate)}

Kenneth W. Smith (Gail)

P.O. Box 114

Shoshone, CA 92384

(H) (619) 852-4328

(W) (619) 852-4303

\section{TONOPAH}

Laurance (Larry) Woods (Pat)

P.O. Box 745

Tonopah, NV 89049

(H) (702) 482-3960

(W) (702) 482-3485

\section{(Alternate)}

Mark E. Howard (JoAnne)

P.O. Box 935

Tonopah, NV 89049

(H) (702) 482-3420

(W) (702) 482-3698 
In addition to the Station Managers and Alternate Station Managers attending the session, we were privileged to have nine "guest teachers" from various communities in Utah, Nevada, and California with us for the full week, and twelve station managers and alternates from the Rocky Flats ComRad program in Denver in attendance for the first three days of the training. The "guest teacher" concept again worked out very well, and will be continued at future training sessions if sufficient funds are made available.

The overall evaluations of the training session from the trainees was very positive. Evaluations and comments are included in Appendix A of this report.

\section{MANAGER PERFORMANCE EVALUATION}

The DRI program manager responsible for hiring and managing the Station Managers and Alternates does a continuous evaluation of these employees throughout the year as has been done in the past. Weekly checks on the regularity of visits to their respective stations, comments and information from other program participants, particularly the EPA staff who have frequent contact with them, personal visits to them in their communities, responsiveness to requests for assistance from other program people, contacts with people with whom they interact, and periodic reports from the individuals are the methods used to evaluate and to make changes as appropriate.

The overall performance of our Station Managers and Alternates continues to improve. With ever-increasing training and knowledge, they have become accepted in their communities as the source for information pertaining activities relating to the NTS and things nuclear. Based

on the above criteria, they are generally doing an excellent job and their spirit of cooperation and interest in the program continue to make them more valuable in this effort. 


\section{SECTION 3}

\section{PUBLIC INTERACTION}

\section{OUTREACH EFFORTS}

The outreach efforts of the program this year continued to focus on presentations made at public meetings and to students in area schools, plus the personal contacts made by program participants throughout the year with officials and residents of the offsite area.

Twenty-six formal presentations were made during the year at 12 locations in Nevada and Utah, with the total attendance reaching 284 adults and 440 students in primary and secondary schools (Table 2). Audience reaction to these efforts was generally very good, with particular interest being shown by the students. The teachers involved in bringing our speakers to their students report very positive feedback, and seem to sincerely appreciate these opportunities to bring a a broader perspective of the world of science, mathmatics, and engineering careers to their classes.

The graphic representation of public contacts in formal presentations (Figure 2) shows the comparison of numbers over the past 12 years. It is interesting to note that nearly half of the contacts made have occurred during the past three years. This coincides exactly with the change in format and methods of identifying audiences.

Documents relating to program outreach activities this year are presented in Appendix B of this report.

\section{SITE VISITS}

Inspection visits to the Community Radiation Monitoring stations are accomplished as a part of the routine trips around the offsite areas by DRI staff. These trips combine audience identification, meeting arrangements, data verification efforts, personal contacts, and other program business with station inspection. All of the stations except Salt Lake City were visited at least twice during the year, and some as many as six times, for various reasons. Other locations and people are visited on a random basis, which requires very little additional effort and positive results are indicated from these visits. 


\section{Table 2}

\section{OUTREACH EFFORTS}

\section{FY 1993}

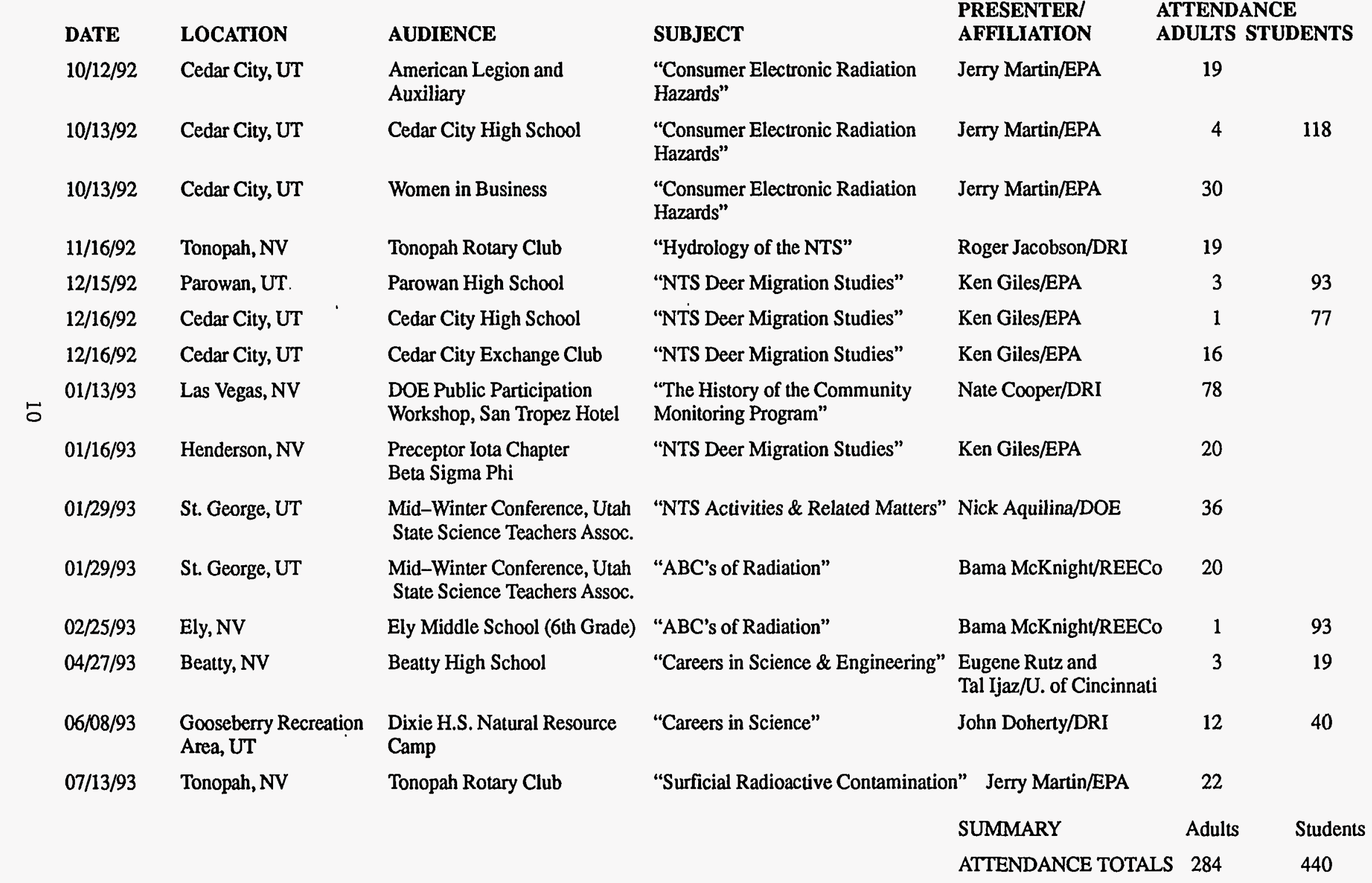


Figure 2

\section{PUBLIC CONTACTS IN FORMAL PRESENTATIONS 1982-1993 \\ COMMUNITY RADIATION MONITORING PROGRAM}

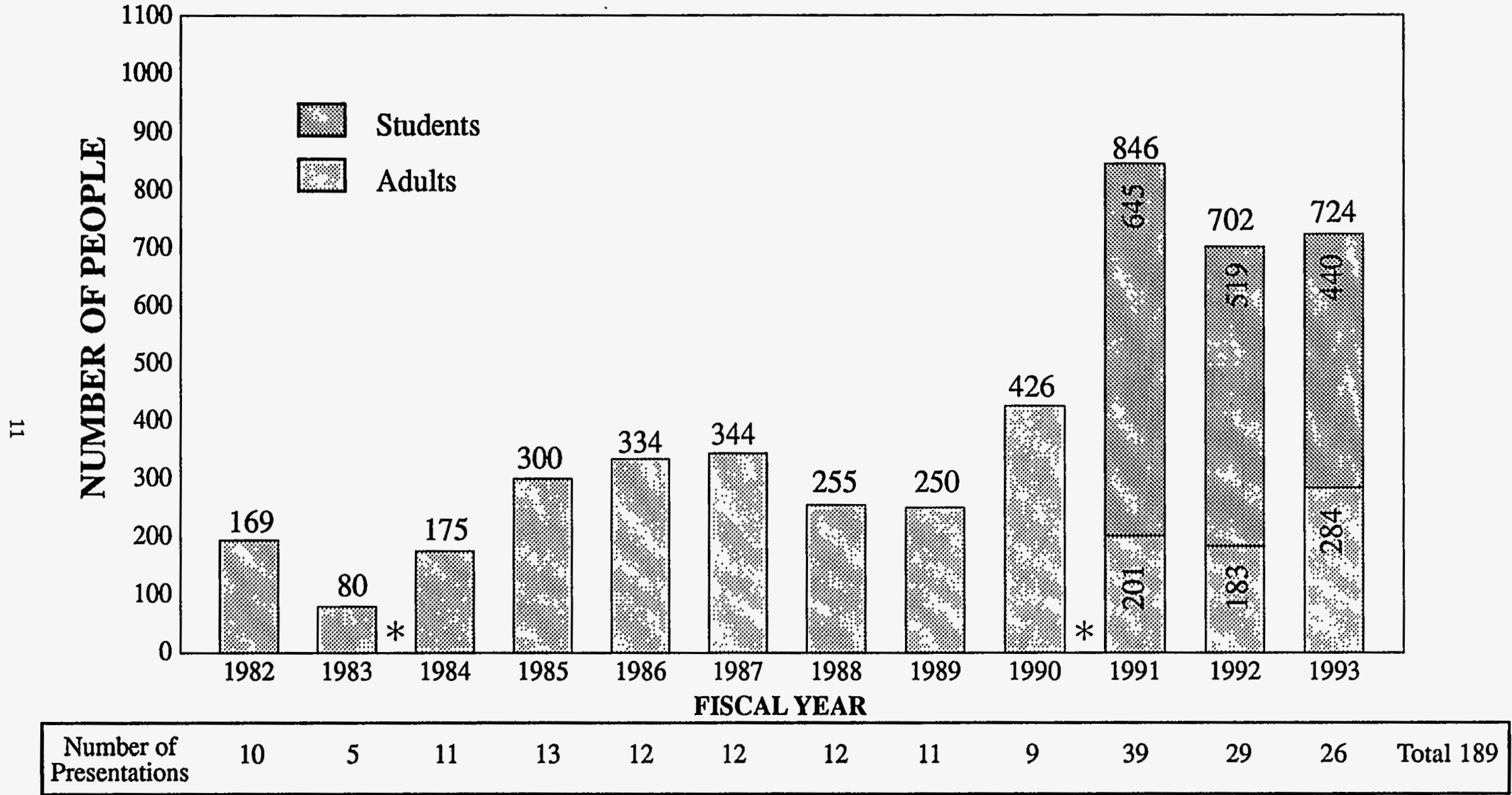

* Changed Format

1982 through $1990-95$ Presentations to 2,333 adults

Attendance

1991 through $1993-94$ Presentations to 688 adults and 1,604 students

Adults $\quad 3,001$

Students $\quad \underline{1.604}$

TOTAL $\quad 4,605$ 


\section{COMMUNICATION}

DRI staff maintains close contact with our employees, the Station Managers and Alternate Station Managers, through telephone calls, correspondence, direct contact during field visits, the clipping service, and other means. Since the moratorium on nuclear testing on October 1, 1993, the quite regular telephone contacts that were made to notify our people of test events has ceased, but other calls are made periodically. Relevant information on anything related to activities at the NTS, the nuclear world, and generally things of interest in the arena of science are regularly transmitted to these employees in order that they may better represent the program in their communities. If the managers require special assistance or information, they rely on DRI, EPA, or DOE to provide that help, and it is there for them.

Contacts with the public in the offsite area continue through a number of avenues. The working relationship between program personnel at DOE, EPA, UUNEL, and DRI is judged to be good, and this makes the program as effective as it is. 


\section{SECTION 4}

\section{DATA VERIFICATION}

During the past several years, DRI staff have attempted to independently verify that at least some of the data collected, analyzed, and reported by the EPA are accurate. DRI continued this year to acquire thermoluminescent dosimeters (TLDs) from a source totally independent from any government contact that are the same brand and type used by EPA. These TLDs are furnished and interpreted by the Radiation Measurements Facility at the College of Engineering and Applied Sciences, Arizona State University in Tempe, Arizona. The TLDs are deployed in the field by DRI staff at approximately the same interval as those installed by EPA, collected by DRI staff, and sent to Arizona State University for analysis and reporting. Those results are then compared with EPA data.

Comparison of results between DRI data and EPA data continue to consistently indicate two things:

1. No data collected and analyzed by either agency indicate that radiation levels at any location were outside the range of natural background, and

2. The data collected by each agency at each location compare favorably enough to indicate that there are no problems with equipment or analysis methods.

Data are on file at DRI and at EPA. Based on these consistent results over several years, it is likely that no TLDs will be fielded by DRI in FY 1994. 


\section{SECTION 5}

\section{SUMMARY}

The primary objective of this program continues to be to inform people living in those communities around the NTS about activities at the NTS and about nuclear-related subjects in general.

The Community Radiation Monitoring Program, approaching its fourteenth year of operation, seems to be in excellent shape. From every indication, the program has been well accepted in the communities surrounding the NTS and there are at least some residents in each of those communities that appreciate the services and information available to them.

The original concept of the program, that of hiring and training people in the communities that would become knowledgeable spokespersons on nuclear matters, has proven to be very successful. That group of 35 people, 8 of whom have been with us since the inception of the program in 1981, remain enthusiastic about the program and have been excellent representatives of the agencies involved. These people are a valuable resource as points of contact in their communities who are accepted, knowledgeable, and are perceived by the community as trustworthy.

Gradual changes in methodology and emphasis of the program continued during this year. Working relationships between program representatives from the agencies involved are in good order, even though some of the characters have changed. As experience teaches us ways to improve our communication with the public, including special interest groups, community leaders, and the younger generation, we continue to get closer to achieving our programmatic and personal goals.

The testing moratorium has and will continue to offer challenges to those involved in the program. It is hoped that the training and experience of program participants can be put to use in furthering other goals and objectives of the DOE. 


\section{REFERENCES}

Cooper, E.N., 1993. COMMUNITY RADIATION MONITORING PROGRAM ANNUAL REPORT - October 1, 1991 - September 30, 1992. DOE/NV/10845-22. Water Resources Center, Desert Research Institute, University and Community College System of Nevada, Las Vegas, $59 \mathrm{pp}$.

Cooper, E.N. and M.A. Jones, 1982. COMMUNITY RADIATION MONITORING PROGRAM ANNUAL REPORT. DOE/NV/10162-3. Water Resources Center, Desert Research Institute, University of Nevada System, Las Vegas, 273 pp.

Cooper, E.N., M.A. Jones and C.B. Thompson, 1985. COMMUNITY RADIATION MONITORING PROGRAM ANNUAL REPORT. DOE/NV10384-08. Water Resources Center, Desert Research Institute, University of Nevada System, Las Vegas, 280 pp.

Cooper, E.N., M.A. Jones and C.B. Thompson, 1986. COMMUNITY RADIATION MONITORING PROGRAM ANNUAL REPORT. DOE/NV/10384-14. Water Resources Center, Desert Research Institute, University of Nevada System, Las Vegas, 105 pp.

Cooper, E.N., R.P. Lucas, Jr. and C.B. Thompson, 1988. COMMUNITY RADIATION MONITORING PROGRAM ANNUAL REPORT. DOE/NV/10384-24. Water Resources Center, Desert Research Institute, University of Nevada System, Las Vegas, $55 \mathrm{pp}$.

Cooper, E.N., and R.D. McArthur, 1991. COMMUNITY RADIATION MONITORING PROGRAM ANNUAL REPORT, October 1, 1989-September 30, 1990. DOE/NV/10845-11. Water Resources Center, Desert Research Institute, University of Nevada System, Las Vegas, 56 pp.

Cooper, E.N., and R.D. McArthur, 1992. COMMUNITY RADIATION MONITORING PROGRAM ANNUAL REPORT - October 1, 1990 - September 30, 1991. DOE/NV/10845-14. Water Resources Center, Desert Research Institute, University and Community College System of Nevada, Las Vegas, $55 \mathrm{pp}$.

Douglas, G.S., 1983. A COMMUNITY RADIATION MONITORING PROGRAM SURROUNDING THE NEVADA TEST SITE: ONE YEAR OF EXPERIENCE. EPA-600/3-83-040. Environmental Monitoring Systems Laboratory, Office of Research and Development, U.S. Environmental Protection Agency, Las Vegas, Nevada, $30 \mathrm{pp}$.

Fontana, C.A., N.R. Sunderland, S.C. Black, B.B. Dicey, A.N. Jarvis, K.S. Moroney, A.A. Mullen, V.E. Niemann, D.D. Smith, and E.A. Thompson, 1988. OFF-SITE ENVIRONMENTAL MONITORING REPORT: RADIATION MONITORING 
AROUND UNITED STATES NUCLEAR TEST AREAS, CALENDAR YEAR 1988. EPA/600/489/019, May 1989, Environmental Monitoring Systems Laboratory, Office of Research and Development, U.S. Environmental Protection Agency, Las Vegas, Nevada, $136 \mathrm{pp}$.

Jones, M.A., and E.N. Cooper, 1984. COMMUNITY RADIATION MONITORING PROGRAM ANNUAL REPORT - December 1, 1982 to March 31, 1984. DOE/NV/10162-17. Water Resources Center, Desert Research Institute, University of Nevada System, Las Vegas, $106 \mathrm{pp}$.

Lucas, R.P., Jr., and E.N. Cooper, 1989. COMMUNITY RADIATION MONITORING PROGRAM ANNUAL REPORT - October 1, 1987 - September 30, 1988. DOE/NV/10162-17. Water Resources Center, Desert Research Institute, University of Nevada System, Las Vegas, $47 \mathrm{pp}$.

Lucas, R.P., Jr., E.N. Cooper, and R.D. McArthur, 1990. COMMUNITY RADIATION MONITORING PROGRAM ANNUAL REPORT - October 1, 1988 September 30, 1989. DOE/NV/10845-01. Water Resources Center, Desert Research Institute, University of Nevada System, Las Vegas, 49 pp. 


\section{APPENDIX A}

Station Manager Training Sessions 


\section{STATION MANAGERS WINTER TRAINING SESSION}

\subsection{JANUARY 1993}

CONTINENTAL HOTEL, 4100 Paradise Road, (702) $737-5555$, (800) $777-4664$

Desert Research Institute, 755 East Flamingo Rd, Las Vegas, NV-(702) 895-0455

Sacurdaye Jun 1923 Activity (Tour of DOE's Neyada Test Slte)

6:20 AM Assemble at Front Entrance of Continental Hotel and load on buses

$6: 35$ AM

7:50 AM

8:10 AM

8:15 AM

8:20 AM

8:25 AM

8:40 AM

9:10 AM

9:50 AM

10:20 AM

Depart for Mercury

Arrive at Mercury Badge Office for Badging (Photo ID is required for badging)

Depart for Gale 100

Arive at Gale 100 for badge check:

Depar for Mescury Cafeteria

Arrive at Mercury Cafeleria. Escons pickup water containers and box lunches from cafeleria

Depart for Field Opcrations Center (FOC) at Area 25

Arrive at FOC. Transfer into vans

Arrive Yuccia Mountain. Briefing on Yucca Mountain Sitc by Characterization Office Representative

Depar for Field Operations Center (FOC) al Area 25

10:50 AM

Artive at Ficld Operations Center and transfer into buses. Sce respective bus schedule below

11:00 AM Depart for Fronchman Flal

11:45 AM Arrive Frenchman Flal. Drive thru brief on weapons cfrects icsts and Liqueficd Gaseous Fuels Spill Test Facility

12:00 PM Depart for Control Poinl-1 (CP-1)

12:15 PM Artive al CP-1. Bricfing by escon.

See "Testing Nuclcar Weapons" \&

"NTS Events" films. Lunch

1:00 PM Depan for Bilby Crater

$1: 15 \mathrm{PM}$

1:25 PM

1:40 PM

1:50 PM

2:05 PM

2:20 PM

2:35 PM

$2: 45 \mathrm{PM}$

2:55 PM

3:05 PM

3:50 PM

4:00 PM

4:05 PM

4:10 PM
Arive at Bilby Craler.

Depar for Sedan Csaler

Arrive at Sedan Crater

Depart for Tunncl Ponds

Arrive al Tunncl Ponds

Depart for Area I Drill Yard

Arrive al Arca I Drill Yard

Depar for site of Apple II houses

Arrive at site of Apple Il houses

Depar for Mercury Cafecteria

Arrive at Mercury Cafeteria. Esecri retums

wuter containcr to cafelcria supervisonr.

Depart for Galc 100

Arrive-al Gate 100 for badge check

Depar for Continental Hotel in Las Vegis

\begin{tabular}{|c|c|}
\hline & BUS 2 \\
\hline $11: \infty$ AM & Depan for Tunnel Ponds. Lunch cnroutc. \\
\hline $12: 20 \mathrm{AM}$ & Arrive at Tunnel Ponds \\
\hline $12: 35 \mathrm{PM}$ & Depar for Area I Drill Yard \\
\hline $12: 50 \mathrm{PM}$ & Arrive at Area 1 Drill Yard \\
\hline 1:00 PM & Depart for site of Apple Il houses \\
\hline $1: 10 \mathrm{PM}$ & Arrive at site of Apple II houses \\
\hline 1:20 PM & Depar for Sedan Crater \\
\hline 1:35 PM & Arrive at Scdan Crater \\
\hline $1: 4.5$ PM & Depar for Bilby Crater \\
\hline $2: 0$ & Arive at Bilby Crater. \\
\hline 2:1 & Depart for Control Point-1 (CP.1) \\
\hline & $\begin{array}{l}\text { Arrive al CP-1. Bricfing by cscort. } \\
\text { Scc "Tcsting Nucicar Weapons" \& } \\
\text { "NTS Events" films. }\end{array}$ \\
\hline $3: 10 \mathrm{PM}$ & Depart for Frenchman Flat \\
\hline & $\begin{array}{l}\text { Arrive Frenchman Flat. Drive thru brief } \\
\text { on weapons cffocts lests and Liquefied }\end{array}$ \\
\hline & Gascous Fucls Spill Tcst Facilliy \\
\hline $3: 40$ & Depart for Mcrcury Cafcicria \\
\hline & Arive at Mercury Caleteria. Escont returns \\
\hline & Depar for Gate 100 \\
\hline & Artive at Galc 100 for \\
\hline & for Continental Holcl in Las Vegas \\
\hline
\end{tabular}

5:30 PM Arrive at Continental Hotel

5:35 PM K-T bus and escon depan for DOENV Building

5:55 PM Arrive al DOE/NV Building

7:00 PM Dinner at Nick's Supper Club

- 15 Luke Mead Drive, Henderson NV 


\title{
NTS Itinerary
}

\section{Community Radiation Monltoring Station Managers And Dependents}

\author{
January 9, 1993
}

6:00 a.m. K.T buses arrive at U.S. Department of Energy's Nevada Field Office (DOE/NV) Building, 2753 South Highland. Meet Darwin J. Morgan, Bus No. 1, and Derek S. Scammell, Bus No. 2, Public Affairs Officers, DOE/NV.

6:05 a.m. Depart for Contlnental Hotel, 4100 Paradise Road.

6:20 a.m. Arrive at Continental Hotel. Meet E. Nathan Cooper, Roger L. Jacobson, DRl; and visitors at front entrance.

6:35 a.m. Depart for Mercury.

7:50 a.m. Arrive at Mercury Badge Office for badging.

Photo identification is required at time of badging.

8:10 a.m. Depart for Gate 100.

8:15 a.m. Arrive at Gate 100 for badge check.

8:20 a.m. Depart for Mercury Cafeteria.

8:25 a.m. Arrive at Mercury Cafeteria. Escorts pick up water containers and box lunches from cafeteria supervisor.

8:40 a.m. Depart for Field Operations Center (FOC), Area 25.

9:10 a.m. Arrive at FOC. Transfer into vans.

9:20 a.m. Depart for top of Yucca Mountain.

9:50 a.m. Arrive at top of Yucca Mountain. Briefing by Yucca Mountain Site Characterization Office representative. 
10:20 a.m.

10:50 a.m.

Bus 1

11:00 a.m.

11:45 a.m.

12:00 Noon

12:15 p.m.

1:00 p.m.

1:15 p.m.

1:25 p.m.

1:40 p.m.

1:50 p.m.

2:05 p.m.

2:20 p.m.

2:35 p.m.

2:45 p.m.

2:55 p.m.

3:05 p.m.

3:50 p.m.
Depart for FOC.

Arrive at FOC. Transfer into buses.

Depart for Frenchman Flat.

Arrive at Frenchman Flat. Drive-through briefing on weapons effects test structures and Llquefied Gaseous Fuels Splll Test Facility.

Depart for Control Point-1 (CP-1).

Arrive at CP-1. Briefing by Morgan. Show "Testing Nuclear Weapons" and "NTS Events" films. Lunch.

Depart for Bilby Crater.

Arrive at Bllby Crater.

Depart for Sedan Crater.

Arrive at Sedan Crater.

Depart for Tunnel Ponds.

Arrive at Tunnel Ponds.

Depart for Area 1 Drill Yard.

Arrive at Area 1 Drill Yard.

Depart for site of Apple II houses.

Arrive at stte of Apple II houses.

Depart for Mercury Cafeteria.

Arrive at Mercury Cafeteria. Escort returns water container to cafeteria supervisor. 


\begin{tabular}{|c|c|}
\hline $4: 00$ p.m. & Depari for Gate 100. \\
\hline 4:05 p.m. & Artvo at Gate 100 for badge check. \\
\hline $4: 10$ p.m. & Tepart for Continental '-iotal. Las Voges. \\
\hline $5: 30$ p.m. & Arrive at Continsn:el Stctel. \\
\hline 5:35 p.m. & KT Jus and escort derart for DOE/NV Euliding. \\
\hline 5:55 p.m. & Arriva at DOENWV Euilding. \\
\hline
\end{tabular}

\section{Bus 2}

11:00 a.m. Depart for Tunnel Ponds. Lunch enroute.

12:20 p.m. Arrive at Tunnel Ponds.

12:35 p.m. Depart for Sedan Crater.

12:50 p.m. Sitive at Sadan Crater.

1:00 p.m. Depart for Arsa 1 Drill Yard.

1:15 p.m. Arrive at Area \{ Drill Yard.

1:25 p.m. Depart for site of Apple ii houses.

1:35 p.m. Arrive at site of Apple !! nouses.

1:45 p.m. Depart for Bllby Crater.

2:00 p.m. Arrive at Bilby Crater.

2:10 p.m. Depart for CP-1.

2:25 p.m. f.rive at CP-1. Briering by Scammell. Shew :Testing Nuclear Viveapons" and "NTS Events" films.

3:10 p.m. Depart for Frenchman Flat. 
FROM:ULCD REED DOE

T0:702 $995 \quad 0427$

JAN 6,1993

$9: 17 \mathrm{AM}$

P. 05

$-4 \cdot$

3:25 p.m. Arrive at Frenchman Flat. Drive-through briefing on weapons effects test structures and Liquefied Gaseous Fuels Spill Test Facility.

3:40 p.m. Depart for Mercury Cafeteria.

3:55 p.m. Arrive at Mercury Cafeteria. Escort returns water container to cafeteria supervisor.

4:05 p.m. Depart for Gate 100.

4:10 p.m. Arrive at Gate 100 for badge check.

4:15 p.m. Depart for Continental Hotel, Las Vegas.

5:30 p.m. Arrive at Continental Hotel.

5:35 p.m. K-T bus and escort depart for DOE/NV Building.

5:55 p.m. Arrive at DOE/NV Building.

$-30-$

A-5 
ATTENDEES

WINTER TRAINING SESSION

Las Vegas, Nevada

January 9-10, 1993

$\begin{array}{lll}\text { ALAMO } & \text { Dell Sullivan } & \text { Alternate Manager } \\ \text { AMARGOSA VALLEY } & \text { Kenneth G. Garey } & \text { Station Manager } \\ \text { AUSTIN } & \text { No attendance } & \\ \text { BEATTY } & \text { John C. Lisle } & \text { Station Manager } \\ \text { CALIENTE } & \text { Judy Foremaster } & \text { Station Manager } \\ & \text { Brent H. Perkins } & \text { Alternate Manager } \\ \text { CEDAR CITY } & \text { Glade V. Sorensen } & \text { Station Manager } \\ & \text { Donald Newman } & \text { Alternate Manager } \\ \text { DELTA } & \text { Beverly Jean DeWyze } & \text { Alternate Manager } \\ \text { ELY } & \text { Gloria Ann Mullen } & \text { Alternate Manager } \\ \text { GOLDFIELD } & \text { Myron A. Johnson } & \text { Station Manager } \\ \text { INDIAN SPRINGS } & \text { James M. Hopkin } & \text { Station Manager } \\ & \text { Larry L. Hathhorn } & \text { Alternate Manager } \\ \text { LAS VEGAS } & \text { Don M. Curry } & \text { Station Manager } \\ & \text { David J. Peltz } & \text { Station Manager } \\ \text { MILFORD } & \text { Dale E. Jensen } & \text { Station Manager } \\ & \text { Morden Leon Gay } & \text { Alternate Manager } \\ \text { OVERTON } & \text { Jack W. Nelson } & \text { Alternate Manager } \\ \text { PAHRUMP } & \text { Albert J. Giannotti } & \text { Station Manager } \\ & \text { Daniel J. Donnelly } & \text { Alternate Manager } \\ \text { RACHEL } & \text { Christy S. Castleton } & \text { Station Manager } \\ & \text { Ruth Agee } & \text { Alternate Manager } \\ \text { SALT LAKE CITY } & \text { Gary M. Sandquist } & \text { Station Manager } \\ \text { ST. GEORGE } & \text { John F. (Jack) Heppler } & \text { Station Manager } \\ & \text { Kelly N. Bringhurst } & \text { Alternate Manager } \\ \text { SHOSHONE } & \text { Brian W. Brown } & \text { Station Manager } \\ \text { TONOPAH } & \text { Kenneth W. Smith } & \text { Alternate Manager } \\ & \text { Lawrence (Larry) Woods } & \text { Station Manager }\end{array}$




\section{COMMUNITY RADIATION MONITORING TRAINING SESSION \\ STATION MANAGER REPORTS \\ January $9-10,1993$ \\ LAS VEGAS, NEVADA}

Nate Cooper

Nate invited the Station Managers and Alternates to give their Station Manager reports.

Larry Woods, Station Manager - Tonopah, NV:

Larry

The Tonopah Test Range has lost their REECo contractor, so some workers have been laid off. Loral, a non - union contractor, took over the contract and hired some of the workers back, so the population hasn't declined much this year. The Middle School has gone up in enrollment. The community attitude is the same, kind of indifferent. Larry showed the VCR tape "Ten Seconds That Shook the World" on the Pearl Harbor anniversary to 606 th graders and 558 th graders. Larry had class discussion on dropping atomic bombs on people, and what would have happened if the Germans had developed the atomic bomb before the U.S. He indicated some good discussions followed. He has talked to the school principal and has arranged a tour of Yucca Mountain on January 20 for the 6th graders, and for the 7th graders in February. The equipment is running great, and he really appreciates the route men. They are doing a fantastic job. They leave notes whenever they change out equipment or do something, so he always knows what's been done. On improvements, Larry has the feeling from his community that he has tapped the civic leaders and organizations, he personally feels that he is pushing it on them, rather than them asking for the presentations. He suggested that DOE or DRI put an ad in the local newspaper announcing that programs are available, and where to contact. The dinner was great last night, and the NTS tour needed more places to get out.

Brian Brown, Station Manager and Ken Smith, Alternate - Shoshone, CA:

Brian

The population is decreasing. There are more foreign tourists coming through. Very little interaction. Brian has given two tours to people visiting. The air sampler went down, but was replaced quickly. There is a Solar II project going on in Barstow and he thinks it would be interesting to hear about their program at the Summer training session.

Ken

$\overline{\mathrm{Ken}}$ toured the station with their entire new teaching staff, and she was very interested.

Jack Heppler, Station Manager and Kelly Bringhurst, Alternate - St. George, UT:

Jack

There have been no equipment problems. The route people have been phenomenally good. The only thing going on in St. George is people moving in and a lot of building going on. The 
area is growing very rapidly. He and Kelly are very pleased with the relocation of the station to the grounds of Dixie College. Interaction hasn't changed much. He doesn't detect much change on the part of the people. They are either very much for it or much against it, and there is a large group in the middle who think he is doing weather data. He continues to get a lot of calls generated through the Chamber of Commerce. Nick Aquilina and Bama McKnight will be speaking at the Utah Science Teachers Association Conference to be held at Dixie College January 29 and 30. It has been some time since Jack has been contacted by the Lions Club. In the past he has given talks at the Lions, Kiwanis, Elks, and the Exchange Clubs, but the main concern in St. George at present is the economic growth. Jack and Kelly have both applied for partnerships to do summer work at the NTS and the EPA office in Las Vegas through an organization funded by DOE, EPA, and private industry called Partnerships in Environmental Technical Education (PETE). They have received word that both of them have been accepted. Everything has gone well, with no equipment problems.

\section{Christy Castleton, Station Manager and Ruth Agee, Alternate - Rachel, NV:}

\section{Christy}

The outstanding event in Rachel is they now have the highest power rate in the state of Nevada with an $88 \%$ increase. There will probably be a lot of things closing out due to the increase. The community attitude is about the same, everyone knows about the station. There are a few tourists that come through and inquire about it, however, there is very little interaction with the people. There hasn't been a town meeting there for some time. There have been very few problems with the equipment. There was a communication problem when she and Ruthie were both out of town at the same time. They both thought the other one was doing the station, so the route men did it for two weeks.

\section{Al Giannotti, Station Manager and Dan Donnelly, Alternate - Pahrump, NV:}

Al

There are few outstanding events in Pahrump. There continues to be a population increase, but no student increase. No change in the community attitude, they don't seem to care. The only major problem encountered with the equipment is on the four bottle system, when the power went out in Pahrump it wouldn't restart. Al contacted Herb and Jeff and they told him what to do to restart it.

\section{Dan}

Dan organized Yucca Mountain trips for the students. They have taken two trips and another one is scheduled in May. Eighty students went November 19, and 80 on December 3. There had to be one chaperone for ten students, so three teachers and seven community people went on each trip. The comments were good. Dan took his energy class to the monitoring station for a tour last week and took pictures of the group. While they were there about six people who work in the community center watched the presentation. They were quite interested as they thought it was just a weather station. 
Jack Nelson, Alternate - Overton, NV:

Jack

For outstanding events, the high school took the football championship, with Nick Bowler as coach. The new school will be occupied this fall. It is located some distance from the monitoring station. The population is on the increase. There is still interaction with the scout groups touring the station and some of the community people. The equipment runs well.

\section{Dale Jensen, Station Manager and Leon Gay Alternate - Milford, UT:}

\section{Dale}

The outstanding event in their community is they got natural gas in Milford. The hog farm is still in the works. If this project goes the community will probably double in size. The community attitude toward the monitoring program has always been positive. Dale uses much of the information he gets at the training sessions in his science class work at Milford High School. He has taken his physics classes to visit the station. The equipment is working well, the air board went out the other day, however it has been real cold.

\section{Don Curry, Station Manager and David Peltz, Alternate - Las Vegas, NV:}

Dave

Three new casinos are being built in Las Vegas. After the summer session Don put together a video tape of the monitoring station and its purpose. That has been used with some of the classes at the high school. The group first took a tour to the Nevada Test Site, then after the tour they returned to the school and watched the video on the station operation. He and Don plan to make contact with Daryl Thome' at EPA on the procedure of processing the information from the stations. Don would also like to video EPA's tour and show that procedure of assimilation of the recorded station data. The Las Vegas station is moving, as UNLV is going to build a physics building at the station location. The station will be moved to the front of the EPA building.

\section{Jim Hopkin, Station Manager and Larry Hathhorn, Alternate - Indian Springs, NV:}

Jim

The biggest event in Indian Springs is there is a new principal at the Indian Springs schools. There have been a couple of delegations from Los Alamos visit the Indian Springs station, because Chuck Costa is trying to get a monitoring network set up for Los Alamos. There is some interest in the station, but there is almost no anxiety about radiation from NTS. Jim was working at the station when some people came by and seemed to have misgivings about the station, but Jim explained the mission of the station. Jim said that he had probably caused problems for the people analyzing data at the station as he has had heart tests, and was radioactive for some time. They have had good service from the equipment. The PIC went down, and it happened to be the day that Chuck Costa and his group from Los Alamos visited. That is the only problem. 
Myron Johnson, Station Manager - Goldfield, NV:

Myron

Thing have been quiet in Goldfield, and somewhat overshadowed with the political climate. One of their commissioners was dismissed due to a violation of the open meeting law. A new commissioner has been appointed by the Governor. During the last six months the mines have reopened. There has been a cooperative agreement between two companies and the mines. The attitude in the community about the monitoring program is that of apathy. There is a stability of people who have lived there for years and feel comfortable with it and have accepted it. Myron has had contact with about 12 or more people making inquiries as he has been at the station. In regard to questions about the equipment readings and possible harmful effects, Myron responded that during the years that he has been Station Manager he has seen very few unusual readings. If they show an interest he explains the equipment and operation of the station. There was a problem with the PIC for a couple of weeks, but it was corrected by EPA.

\section{Gloria Mullen, Alternate - Ely, NV:}

\section{Gloria}

There has been a population surge in Ely, not in the town but in the Community Monitoring program thanks to Becky Murdock. She is expecting again. Jobs are needed badly in Ely. The community attitude is good. The surveys she has done with some of the groups she has taken to tour the station have all been favorable. Despite the way they felt about testing they feel comfortable having the monitoring station in the town. Many of them remember the days when the clouds came over Ely, so feel safer because of the monitoring station and someone in town they can ask questions if there is a concern. There have been few interactions this year. Ely has had an extremely rainy summer and a very cold and snowy winter. There are drifts of snow around the station, so they have to climb over the drifts to get to the station. There was a slight problem with the timer on the air sampler.

Beverly DeWyze, Alternate - Delta, UT:

\section{Beverly}

There is nothing too significant in Delta. They do have natural gas now. The schools have been closed due to the cold snowy weather. The community attitude is accepting, somewhat apathetic. There has been about 75 visitors to the station, including two classes with 30 students each which Tom Judd took for a tour of the station. No equipment problems. Tom says he finds the winter session difficult to attend, especially on Sunday. Personally Beverly likes it the first part of January.

Don Newman, Station Manager and Glade Sorensen, Alternate - Cedar City, UT:

Don

$\overline{C e d a r}$ City is experiencing a real building boom. There is a lot of new industry coming in. A 
company is manufacturing air bags, and a new office furniture supplier is moving in with 300 new jobs. The city is really growing. The attitude toward the program has been positive. Don has had some interesting things happen with public interaction. One of the City Council members called him to get some information about radiation data. There was a company considering a move to Cedar City that wanted this. Don gave him some of his previous reports showing the radiation compared to the surrounding areas. Nate, Ken Giles, and Jerry Martin have come and presented talks to the American Legion, Exchange Club, Women in Business, Cedar City High School, and Parowan High School, so there has been a lot of interaction. The only equipment problem they have had is with the monitor, probably because of the wet winter which was probably the cause of the problem. The route men got it taken care of real quick, and he expressed his appreciation for their efforts.

\section{Judy Foremaster, Station Manager and Brent Perkins, Alternate - Caliente, NV:}

Judy

Not much has changed in Caliente. Judy runs the public information office on the Nuclear Waste Program in Caliente. Since last February she has been moved to a larger office location, that has a TV and VCR so now she has somewhere for the people to go for additional information when they inquire about the station. She received a call from a man in California that had visited the station on the weekend and called for information on the Community Monitoring program for his thesis work. Also a call from a person who was coming up to check out the UFO's so wanted to know if a nuclear test was scheduled for that weekend. In coordination with her other job she has put a speakers' bureau together for the community and all the information she has received from DRI will be in there.

Brent

There are two new county commissioners, one is Floyd Lamb. He has somewhat overshadowed the other commissioner. They also have the first female county commissioner in Lincoln County history. Brent showed the video "Ten Seconds that Shook the World" to the 5 th and 6 th graders. The students were real interested and asked questions.

John Lisle, Station Manager - Beatty, NV:

John

Important events that have happened in Beatty are the girls volleyball team took state championship, and the high school academic olympic team took state championship. There was a power pole down in Indian Springs that knocked the power out in Beatty because of a 30 year old relay. When the NTS started coming on line it just overloaded everything. The Low Level Dump Site in Amargosa has been closed. The only person that lost his job due to that closing was Ken Garey. There was some news media coverage but there was no effect to Beatty. The U.S. Ecology hires about 30 people and they do very little in the nuclear disposal area. For several years when there was something to bury on the nuclear site, they just brought someone over from the chemical site to bury it; so that part didn't change. There is no change in the community attitude. By the use of the transparencies he gave an overview of the station to 48 
students. EPA loaned him ten instruments to do some surveillance. He hid some stuff around the school and classroom and they had to find it, and the students really enjoyed that. John took a visitor on a tour of the station: Nate's brother. The noble gas sampler quit with the first cold weather, so called Herb and it was fixed in a couple of days.

\section{Austin Report:}

Nate had two comments. It's cold and snowing in Austin and the population is increasing. Loretta and Bill Cox have a new baby.

\section{Ken Garey, Amargosa Valley, NV:}

\section{Ken}

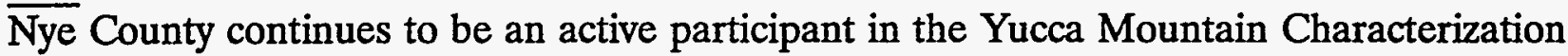
studies. They have advertised hiring an on-site inspector and somebody to manage the Yucca Mountain investigation program. Nye County is also severely impacted by the Nevada Test Site layoffs and tax cut decisions. The third event was the closing of the Beatty Low Level Radioactive Waste Disposal Site. Ken had formed a small company that did onsite inspections on loads. He inspected the trucks prior to the inspection of the State inspector. With the closing of the site that job opportunity is gone. The attitude of the local citizens are complacent, but the number of visitors he interfaces with are impressed with the Community Monitoring program. There are a lot of truck drivers that were bringing in low-level waste. Probably 800 loads of waste were inspected at Beatty. While the trucks were parked near the Amargosa station some of the truck loads would reflect a high reading, some up to 35-40 mR. Herb called to see if a truck was parked close to the station, which it had been, so it shows that the instruments do work. The Amargosa Valley Advisory Board has appointed a nuclear steering committee with Ken as chairman. A current reading file of newspaper clippings is available in the public library, sent out by DRI. The noble gas equipment is non-functional as there is an electrical power problem which is being resolved. Ken suggested that the stations have more environmental aspects of local interest, the weather, climate, and seismic events. There was a seismic event within eight miles of the station and Ken received inquiries as to whether the barograph recorded the event.

Nate With reference to the reading material sent out, a lot of the clippings come from the Department of Energy. DOE has a person who collects these articles from a much wider range of publications than is available at DRI. It has been most helpful in assembling the material. Gloria Mullen inquired if it would be all right to put the news clippings in the Ely High School Library, and Nate responded to the affirmative, as it is all public information.

Dell Sullivan, Alternate - Alamo, NV:

Dell

For outstanding events it has snowed three times in Alamo. The community attitude remains the same. Rick takes his science classes to the station, and he has his students working on 
science projects much of the time. The equipment is working good. The noble gas unit has trouble when the weather is cold, but it improves when the weather warms up.

JoAnne Burrows asked if the Station Managers/Alternates had received the tapes and material that they requested from the Summer training session. If they didn't get what they requested just contact her. A video tape is being put together of Bama McKnight on the "ABCs of Radiation." It will be sent to you when it is completed, if you request it.

\section{Gary Sandquist, University of Utah - Salt Lake City, UT:}

\section{Gary}

The events of interest are best described by the "good news" and "bad news." The good news is that Wayne Owens decided to run for Senator in Utah against Robert Bennett, and Robert Bennett won. Wayne Owens' comment was that he is through with politics. A woman, Karen Shepherd, also won for the Congress. She is an environmentalist and is also very opposed to nuclear testing, as was Wayne Owens. Another interesting item is that mixed waste is waste that has both hazardous components and radioactive components. It prompts an item of great concern because you involve two Federal agencies, the NRC and the EPA. That will be a great challenge for two Federal agencies to agree. Gary went to Brookhaven National Laboratory. The principal problem is they have some radioactive materials in the soil, particularly tritium. The bulk of the water obtained for Long Island is extracted from aquifers. There is some evidence that the tritium is moving from the release site, and it may go into the aquifer and show up off the site. Brookhaven is extremely concerned that if the material shows up off site to any extent, that will be the end of Brookhaven National Laboratory. Much of the waste is materials that came about from the 50's, 60's and 70's when Brookhaven was a premier physics laboratory. Enviro Care of Utah has recently opened up an exploratory facility that will handle mixed waste on a limited interim period. It is an issue to be addressed and something has to be done, as in many cases there are mixed wastes. Gary has used the video "Ten Seconds That Shook the World" in his university classes. The video provides some of the historic perspective and some of the decisions that the politicians had to make.

The Community Radiation Monitoring Program can't stay the way it has for the past ten years. Changes are expected, and, as Bruce Church stated, the possibility that no significant nuclear testing will occur in the future. What will happen with the CRMP? Gary said that if Yucca Mountain is shown to be the facility to accommodate the nation's nuclear waste, one of the great public concerns is the transportation of the high level nuclear waste to the site. A program such as this might have some contribution along those transportation routes. The CRMP has earned credibility with regard to the testing. Another area in which to develop confidence and expertise is for the Summer training session to address hazardous materials in the environment.

Nate proposed that the Winter training session for 1994 be on January 15-16, a week later than this year to get away from the Consumer Electronic Show and other factors. Some discussion followed as to time preferences. By having it later in January it would give an 
additional week after returning from Christmas break. A poll will be sent out to all the Station Managers and Alternates to find out what dates will be the best.

The Summer training session has been set for August 2-6, 1993, for Brian Head, Utah.

Gary Sandquist Please make any suggestions and recommendations while filling out the evaluation and comment form. Possibly the comments made by one or a few of you will dictate in part the agenda of the program for the training session. Gary plans on inviting someone from USCEA for the Summer training session, as their group could provide some educational resources. Possibly there could be an update on Yucca Mountain. He feels that for the program's credibility and understanding it is good to invite critics that are credible to speak to us at the Summer training session. If anyone has any suggestions, please contact Gary.

Nate in behalf of this group expressed appreciation to the EPA field monitors. A round of applause by all followed. Thanks for coming, and have a safe return trip. 


\title{
COMIMUNITY RADIATION MONITORING PROGRAM STATION MANAGERS TRAINING SESSION
}

\author{
August 2-6, 1993 - Brian Head Hotel, Brian Head, Utah 84719 \\ $1-(801) 677-3000$
}

Sunday, 1 Aug. Activity

6:00 p.m. Pre-Session Social - Get acquainted with CRMP participants

Monday, 2 Aug. Activity

8:00 a.m. Welcome and Introduction: Session Overview

8:15 a.m. Current Events at DOE

9:00 a.m. Break

9:15 a.m. Environmental Conditions at Hanford

10:15 a.m. Break

10:30 a.m. Looking to the Future After Nuclear Weapons Testing

11:15 a.m. Open Discussion (N. Aquilina, R. Nelson, C. Brown, N. Cox)

12:00 noon Lunch

1:15 p.m. DOE Educational Outreach Program:(Morlan, Jones, Schachter, Dey)

3:15 p.m. Break

3:30 p.m. Discussion on Educational Programs

4:00 p.m. Nuclear Power Development in U.S.

5:00 p.m. Session Ends

6:00 p.m. Picnic at Woods Ranch in Cedar Canyon

Tuesday, 3 Aug. Activity

8:00 a.m. Basic Nuclear Science - G. Sandquist

8:50 a.m. Discussion, Questions \& Break

9:20 a.m. Characteristics of Radiation - B. Hardy

10:10 a.m. Discussion, Questions \& Break

10:40 a.m. Radiation Detection - D. Slaughter

11:30 a.m. Discussion, Questions \& Break

12:00 noon Lunch

1:30 p.m. Health Physics Instruments - B. Hardy

2:20 p.m. Discussion, Questions \& Break

2:40 p.m. Biological Effects of Radiation - D. Slaughter

3:30 p.m.

3:50 p.m.

4:40 p.m.

5:00 p.m.

7:00 p.m.

Family Night Entertainment - Brian Head Hotel All invited to participate
League of Women Voters Perspectives

Session Radiation

Discussion, Questions \& Break

Radiation Monitoring \& Sampling-G. Sandquist

Discussion, Questions \& Break

Session Ends

Session: Environmental

Hazardous Materials - D. Slaughter

Discussion, Questions \& Break

Production \& Use - G. Sandquist

Discussion, Questions \& Break

Health Effects - B. Hardy

Discussion, Questions \& Break

Emergency response - D. Slaughter

Discussion, Questions \& Break

Regulatory Issues - G. Sandquist

Discussion, Questions \& Break

G. Sandquist - $U$ of $U$

N. Aquilina , NV Mgr.- DOE

Art Janata - PNL

Chris Brown-Citizens Alert

Norma Cox - League

All participate

R. Neison - DOE

All participate

Kyle Turner - ANS

No Host

Discussion, Questions \& Break 
Session: Radiation

8:00 a.m. Background Radiation - G. Sandquist

8:50 a.m. Discussion, Questions \& Break

9:20 a.m. Radiation Regulations - B. Hardy

10:10 a.m. Discussion, Questions \& Break

10:40 a.m. Rad Waste Management - D. Slaughter

11:30 a.m. Discussion, Questions \& Break

12:00 noon Lunch

1:30 p.m. Station Equipment - D. Thome - EPA

2:20 p.m. Discussion, Questions \& Break

2:40 p.m. Field Operation - D. Slaughter/EPA

3:30 p.m. Discussion, Questions \& Break

3:50 p.m. Station Operation - G. Sandquist/EPA

4:40 p.m. Discussion, Questions \& Break

5:30 p.m. Session Ends

Thursday, 5 Aug. Activity

8:00 a.m. Principles of Meteorology

9:00 a.m. Conclusions of the University of Utah Radiation Studies

10:00 a.m. Break

10:15 a.m. Greenhouse Effects and U.S. Energy Options

12:00 noon Lunch

1:30 p.m. Federal Response to Radiological Emergencies \& Nuclear Incidents

2:45 p.m. DRI Research Activities

3:45 p.m. Break

4:00 p.m.

5:00 p.m.

Meteorology and Nuclear Weapons Testing

Session Ends

6:00 p.m. Cookout at Brian Head Campground

Friday, 6 Aug. Activity

8:00 a.m. Risk from Transportation of Defense Materials in U.S.

9:15 a.m. Yucca Mountain Repository Characterization

10:30 a.m. Break

10:45 a.m. Activities in school programs

12:00 noon. Lunch

1:30 p.m. Station Manager's and Participants Reports

Evaluation of Session

Administrative Details

3:00 p.m. Farewell and Dismissal
Session: Environmental

Handling Haz Mat's - D. Slaughter

Discussion, Questions \& Break

Mixed Waste - G. Sandquist

Discussion, Questions \& Break

Disposal of Haz Mat'ls - B. Hardy

Discussion, Questions \& Break

Station Equipment - D. Thome EPA

Discussion, Questions \& Break

Station Operation - G. Sandquist/EPA

Discussion, Questions \& Break

Field Operation - D. Slaughter/EPA

Discussion, Questions \& Break

Sponsor

D. Randerson-NOAA

R. Lloyd - U of $U$

D. Slaughter - U of U

D. Thome - EPA

J. Doherty - DRI

D. Randerson - NOAA

No Host

Sponsor

G. Sandquist - U of $U$

A. Robison - YMPO

D. Curry

All participate

N. Cooper - DRI

N. Cooper - DRI

G. Sandquist - $U$ of $U$

NOTES: 


\section{ATTENDEES \\ SUMMER TRAINING SESSION \\ Brian Head, Utah \\ August 2-6, 1993}

ALAMO

AMARGOSA VALLEY

AUSTIN

BEATTY

CALIENTE

CEDAR CITY

DELTA

ELY

GOLDFIELD

INDIAN SPRINGS

LAS VEGAS

MILFORD

OVERTON

PAHRUMP

RACHEL

SALT LAKE CITY

ST. GEORGE

SHOSHONE

TONOPAH
Clark M. "Rick" Hardy

Dell Sullivan

Kenneth G. Garey

No attendance

John C. Lisle

Judy A. Foremaster

Donald Newman

Glade V. Sorensen

Melvin Baldwin

Thomas S. Judd

Beverly Jean DeWyze

No attendance

Myron A. Johnson

James M. Hopkin

Larry L. Hathhorn

Don M. Curry

David J. Peltz

Dale E. Jensen

Morden Leon Gay

Nicklas J. Bowler

Jack W. Nelson

Albert J. Giannotti

Christy S. Castleton

Gary M. Sandquist

John F. (Jack) Heppler

Kelly N. Bringhurst

Brian W. Brown

Kenneth W. Smith

Laurance (Larry) Woods

Mark E. Howard
Station Manager

Alternate Manager

Station Manager

Station Manager

Station Manager

Station Manager

Alternate Manager

Emeritus

Station Manager

Alternate Manager

Station Manager

Station Manager

Alternate Manager

Station Manager

Alternate Manager

Station Manager

Alternate Manager

Station Manager

Alternate Manager

Station Manager

Station Manager

Station Manager

Station Manager

Alternate Manager

Station Manager

Alternate Manager

Station Manager

Alternate Manager 


\section{STATION MANAGER REPORTS \\ BRIAN HEAD, UTAH}

August 6, 1993

\section{Nate Cooper, Desert Research Institute:}

Nate introduced the eight guest teachers. Nine guest teachers attended last year and that worked out very well. He said that next year there may be more. Nate invited the teachers to come forward and say a few words about what their reactions have been this week to the session.

\section{GUEST TEACHERS REPORTS}

Jan Carroll, Washington Junior High School, Las Vegas, NV:

Jan said that JoAnne Burrows asked her, "What was the best part of the session?" With the school she works for she doesn't have much of a chance to interact with other people and she felt this was really good for her. It was good to see and hear what is going on, learn about the resources available, and now knowing who to call for information.

Jelena Jensen, Evergreen Junior High School, Salt Lake City, UT:

Jelena said that she really has appreciated the opportunity to be here. She felt that there has been a lot of incredible information given, and what better people to get it from. In Salt Lake, as teachers it is difficult to find accurate information. Students ask questions, and she said that she would look it up, and a week later still no answer to the inquiry. It has been incredible having so many specialists in so many different areas here. The resources were great. Organization was wonderful and it has been a very pleasant experience. She has enjoyed being here, and her students are going to benefit from it, as well as their families and parents.

\section{Sherrie Nelson, Roy High School, Roy, UT:}

She has 100 physics students and last year when they covered nuclear energy, she didn't have a lot to say because she didn't know very much. Now she has a lot to say. Her text book isn't even correct so now she has a lot to share. She really appreciated the opportunity to be here. Now she can take her students to visit the reactor and do some fun things. Where she works mostly with seniors, she tries very hard to funnel them into engineering and science fields. To be here and meet you people and possibly for her students to meet some of you will be a very good opportunity for them to see what the science community is really about. So many of her students live in fear, especially where their parents work at Hill Air Force Base. They know a little bit about nuclear energy and it is frightening to them. This has been a wonderful experience and she expressed thanks for letting her attend and would love to attend again. 


\section{Robin Parkinson, Northridge High School, Layton, UT:}

Robin teaches at Northridge High School, which was just opened this last year. It is known as the Taj Mahal, because the building cost $\$ 54$ million. One of the most exciting aspects of this conference was the technology of it. Their school is a consortium school, with the full purpose to be exposed to technology. They have a technology lab foundation, and hopefully they will get good support from their school district to develop the science technology lab. She has appreciated the resources, the people, and the information on other technology labs that have been set up around the country.

\section{Michael Paul, Dayton High School, Dayton, NV:}

It has been great for him, because his students are really interested in nuclear power and more so in Yucca Mountain. They want to know what is going on there and they don't have a good information base. This has helped him to pull together a lot of resources and information that he thinks will help focus on it.

\section{Catherine Peterson, West Jordan Middle School, West Jordan, UT:}

Catherine was not present for the oral report. These are her written comments. She enjoyed the week. Enjoyed listening to people who were obviously enthused about their work and their commitment to making the world a better place. She learned a lot about radiation and feels she is taking home a lot of information she can use in the classroom, especially to use in current issue discussions as well as information she can use to dispel some myths. She would have enjoyed more "hands on" outdoors experiences. For example, going on a hike and releasing a weather balloon, or flying over the Nevada Test Site, or doing the radiation sweep in the mountains rather than the parking garage. Also, she thought more philosophical and ethic questions could have been explored. If the DOE did some entertaining and informative videotapes for classroom use, and perhaps supplied a unit plan for teachers to use and/or modify, it would be great. If a lot of the technical stuff was simplified down to basic principles for student's understanding and teachers attending could gear it to grade level, that would be great, too.

The ideas shared by the teachers who had transformed woodshops into technology labs were valuable. She loved the idea about the portable lab in a mobile home type arrangement. Also, the business partnerships sounded terrific. Hopefully these could be implemented in her state. Thank you for a great week, an intellectual challenge, stimulating and thought-provoking presentations, and an opportunity she will recommend to other teachers.

\section{Chivukula Shayamala, Bonneville Junior High School, Salt Lake City, UT:}

Chivukula is from India and has been in the U.S. one year. What she expected when she came here was for the schools to have computers, TV, video, and she expected a lot of technology that they don't have in India, but what she found was absolutely nothing. She inherited a lab which has nothing but chemicals which are completely mixed up and nobody was there to tell 
her what they were. She was not familiar with them because they didn't have names to identify them. She was very surprised when she came to the training session and found that everyone was sharing their knowledge. She had contacted more than ten teachers in the Granite School District just to find how they were running their classes. They just were not willing to share their information. She is now in the Master's program at the University of Utah. In talking to the teachers there, even they did not share their information. When she came here to the session and found the teachers talking about so many things, she has been really fascinated, because that is exactly how she would expect a teacher to be. She really enjoyed being here.

\section{Emil Stockton, Wasatch High School, Heber, UT:}

This has been quite a bit better than he had expected it to be. He expected it to be more propaganda, people trying to protect themselves. It has been a real eye-opener for him. It has kind of worn away a lot of his misconceptions that he has been passing on to his students. As a teacher, he feels that one of the main functions is to pass along reliable information. He felt that they got quite a bit of that here and has established some really good contacts. It has been a real good worthwhile experience.

Nate: Thanked the guest teachers for coming and said that if we can invite guest teachers again next year we certainly will.

\section{STATION MANAGER REPORTS}

\section{Rick Hardy, Station Manager and Dell Sullivan, Alternate - Alamo, NV:}

\section{Rick}

The outstanding event was that the school population is up slightly. The community attitude is mild curiosity to indifference. There was the traditional eighth grade tour of the Nevada Test Site. There have been some slight problems with the noble gas sampler and Flo fixed it.

\section{Ken Garey, Station Manager - Amargosa Valley, NV:}

\section{Ken}

The outstanding events were that several of the civic organizations organized and selected members to serve on a nuclear steering committee, according to the town advisory board. It represents a wide variety of people and each member of the committee is required to give a monthly presentation during their year of tenure. The group still maintains a positive attitude toward the Yucca Mountain characterization work, and are grateful for the jobs that have been provided to a number of the community people. No problems with the equipment, just routine maintenance. The station is holding up good. He would still like to see meteorological data collection added to the stations. The teachers could get a lot out of that, and they would get a tremendous amount of interest from the people he associates with. Everybody is interested in wind direction, wind speed, and any atmospheric changes. Ken serves as chairman of the nuclear steering committee and also on the Nye County Nuclear Advisory Committee. He 
attended the Waste Management 1993 meeting in Tuscon, Arizona, and the High Level Nuclear Waste Management meeting in Las Vegas, and is grateful to be able to meet outstanding scientists of the world and hear their presentations.

Austin, NV:

No report from Austin. Station Manager Bill Cox and Alternate Tom Brannan could not attend.

John Lisle, Station Manager - Beatty, NV:

John

The major outstanding event was that EPA brought seven people to the Career Day and did an excellent job. Herb said he wants to come back, and he is welcomed any time. Suggestions for improving the program are two, raises for Juana and Nate.

Judy Foremaster, Station Manager - Caliente, NV:

Judy

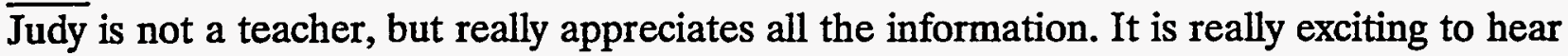
about what's happening in the schools. She is going to take the information back to the people and school district in Lincoln County. Brent Perkins, Alternate, took his class over for a tour of the station then went to Judy's office, the Yucca Mountain information office. Information on both sides of the issues is given out in her office. It was surprising how much they already knew as 5th graders when the students came to her office. Then some of their parents came in. There is a video machine in the office and she can show the different tapes. There are more people stopping by the station now that the depot is being renovated. She would like to have some signs on the equipment like they have in Las Vegas.

Don Newman, Station Manager, Glade Sorensen, Alternate, - Cedar City, UT: and Mel Baldwin, Emeritus

Don

Cedar City has really changed a lot this year. Many of the people are moving in from California and Nevada. There is a tremendous amount of growth. A lot of houses are being built, however, college students are having problems finding places to live. New industry continues to move in. The attitude is still good. Don has asked the high school chemistry department to mention the station operation in their classes. The City Council has come to them for information on air quality, and he gave them some of our reports. He appreciated Nate bringing up presenters to speak to their local community clubs and to the high school. He has also talked to Nate about bringing up more presenters. The equipment has been running good. There was a problem with the air sampler, but Mark changed it the day he came up. 
Tom Judd, Station Manager and Beverly DeWyze, Alternate - Delta, UT:

Tom

There is some talk about different industries coming in, but it is just promotional at this time. The attitude is basically accepting. The visits he gives to the station are from school classes. There isn't a lot of activity at the station. If there is ever an equipment problem it doesn't take EPA long to get it fixed. He appreciates EPA's support, as they are a long distance away from Las Vegas. Tom has never been to a reactor, and he would like to visit one.

\section{Beverly}

This week has been really worthwhile. Some of the things that have occurred to her is that so many of the problems involved are political. She asked Bruce Church for the address of the Secretary of Energy. If a group even this size over this geographical area wrote one letter to the Secretary of Energy it would make more of an impact than talking to all the scientists. That might be something we could do to possibly make an impact.

Ely, NV:

No report from Ely. Gloria Mullen is in Reno being further educated, and Rebecca is doing child raising.

\section{Myron Johnson, Station Manager - Goldfield, NV:}

\section{Myron}

Goldfield hasn't changed much. There is a little bit of mining activity keeping the town going. The community attitude towards the station is very positive. He gets calls from people interested in the background readings and inquiring if anything is happening. He had about 16 different visitors come by as he was maintaining the site. Most of them have been positive. He took a group through from the school for an orientation. There was a little problem with the equipment, but EPA changed it out. He expressed his appreciation for the good support from EPA.

\section{Jim Hopkin, Station Manager and Larry Hathhorn, Alternate - Indian Springs, NV:}

Jim

Indian Springs runs largely on rumors. There is a rumor that the school population could increase considerably, because the base closings have brought a lot more people to Nellis, and they don't have any place to house them. So they may reopen base housing and also build more housing. The outstanding event is there was a homicide in Indian Springs. The community attitude hasn't changed much. A group of people came by the station with dogs on leashes. One man said, "That's set up by the government to fool the people. They want us to believe that really counts something." Jim's reply was that he had had a thallium angiogram procedure and when he walked up to the machine, it did register on the equipment. He invited the man to meet him on another day and he would bring a source to show that the equipment was operational. In completing the landscaping around the new gymnasium at the high school, 
where the station sits, the background radiation at the station has changed by about $2 \mathrm{mR}$ per hour. He had a little problem with the gas sampler, but it has been fixed. They get excellent service from EPA. This year Larry has done more than his share of attending the station when Jim was ill.

\section{Don Curry, Station Manager and David Peltz, Alternate - Las Vegas, NV:}

Don

There isn't too much happening in Las Vegas. The station was moved and it really looks good. The last couple of years in giving the report, he had said that he hadn't seen anyone at the station. This year there has been a lot more visitors, and he feels that moving the station had a lot to do with it. It was previously sitting in the parking lot on the campus where now a new physics building is being built there. It is now in front of the EPA offices. He is trying to get some students involved in using the station. The only problem was the way the PIC is set up. Just about this time of the year it catches the direct sun. He left Lynn a note that there were no numbers on it. All of the inside of the windows have now been painted so that works out well. It would really help if weather instruments could be installed. It could spark interest with the students.

\section{Dale Jensen, Station Manager and Leon Gay, Alternate - Milford, UT:}

\section{Dale}

The outstanding event that occurred in Milford this past year was the county bond election passed. There will be a new high school which will be completed in September 1994. The potential of being the world's largest pig farm is also still progressing. They are talking about slaughtering 40,000 pigs a day. The attitude toward the program has been positive since the start and it still is. Dale has taken some of his science classes from 7 th through 12 th grades, and does a unit in meteorology and he takes the barograph to the school, and the students do a lot of recording from the barograph. There have been very few problems with the equipment. There was a mag tape problem that still has the EPA baffled. It may need a whole new PIC unit put in to get it repaired. However, he did get a report that it started working again, so maybe it fixed itself. He appreciated the conference this summer and enjoys them very much.

\section{Nick Bowler, Station Manager and Jack Nelson, Alternate - Overton, NV:}

\section{Nick}

There are a couple of new things in Moapa Valley. There is a new high school that will open this fall. The old high school now becomes a middle school. A cement plant is to go on-line this fall. As for the community, with Bruce Church and Ace Robison living in Logandale, with experts such as them, if there are any questions or inquiries they would go directly to them. There are scout troops that routinely take tours of the station. He has encountered a few people passing through inquiring about the station. He mainly gets calls from the community people asking for weather information, since many still think it is a weather station. There have 
been no serious problems with the equipment. Jack has been a great help, and he enjoys working with him. He really has enjoyed the presentations and programs this week.

Nate: Dan Donally, Alternate from Pahrump is having some medical problems and couldn't be with us.

\section{Al Giannotti, Station Manager- Pahrump, NV:}

\section{Al}

Greetings from the garden spot of Nevada. There are no outstanding events in Pahrump. The community attitude toward the station is still the same. There has been very little interaction with the public. He attended a program where Mr. Robison of Yucca Mountain Project Office gave a special presentation in Pahrump. It was very good, however, very few people attended the meeting. There have been no problems with the equipment, but there have been problems with Valley Electric, the power company. They neglected to turn on the switch for the electricity to go from the pole down to the equipment. Dan Donally began losing his voice at the end of the schoolyear. Al called Pahrump last night and got a report on Dan. He had a polyp removed from his vocal cords, it is benign and he is much better. The split sessions were good.

Christy Castleton, Station Manager - Rachel, NV:

\section{Christy}

About the biggest news in Rachel is that Ruth Agee is having another baby. There was the annual UFO event, which brought even more people this year, around 400 . Some of them came to visit the station. They showed an interest in what kind of monitoring was being done, and if UFO's could be detected at the station. Rick didn't mention that Alamo is getting a new elementary school, and the high school there will become the middle school, and that will affect Rachel because all the kids go to Alamo to school. Hopefully, that will increase their educational benefits. Most of the interactions have been with tourists. There have not been any problems with the equipment. The routes have been changed, so she doesn't know who is checking the Rachel station. For suggestions, Christy feels that more emergency response type training would be beneficial. In putting signs at the station like the Las Vegas station, it would be helpful in explaining the equipment to visitors. She enjoyed the session and the guest teachers were real enjoyable.

\section{Gary Sandquist, University of Utah - Salt Lake City, UT:}

\section{Gary}

A lot of things have happened in Salt Lake City but in his area one of the most significant things was to have Steven Hawking come to Salt Lake. Hawking is an incredible young man. He has Lou Gehrig's disease and speculation is that he will not survive another five years. He is the leading cosmologist in the world. He has written a book that was a best seller in England. He is the Lucasion Professor of Mathematics at Cambridge, the same position once held by Sir Isaac Newton. With his handicap, his only means of communication with the outside world is 
through a computer. He gave his presentation through his computer at the Salt Palace. There were 4,000 people turned away on a July 4 weekend. He lectured about black holes cosmology and other things.

There have been relatively few problems with the equipment. The EPA crew comes up on a monthly basis. The equipment is used in the nuclear laboratory class. It is one of the important data base points they make in the point of view of radiation measurements. The University of Utah is a major user of radioactive materials and it is part of the NRC license to provide an annual report on environmental substance evaluation. The state has a new Bureau of Radiation Control. It was more of a political appointment as the person selected to head the Bureau has no radiation background. Gary wrote a letter to the governor and others trying to promote the appointment of somebody with some radiation background, but that didn't occur. The station gets a lot of traffic from people going to and from the parking lot. Many of them stop and ask for information about it. The idea of some new signs describing the equipment and station would probably work out well.

\section{Jack Heppler, Station Manager and Kelly Bringhurst, Alternate - St. George, UT:}

\section{Jack}

Jack stated that he was one of the ones that came up with the idea that the format for Station Manager reports that is used is somewhat redundant. This has been a good conference and he has really enjoyed it. He hopes that when somebody writes the history of this program and it becomes a done deal some day, that they remember people like Juana and Nate who really pull this thing together. They just don't get enough credit for what they do. He also hopes that somebody remembers the people who are now sitting in the back from EPA. They are the ones that are keeping the program going. You are missing out if you don't bother to thank people like Flo and Jeff and all the rest of them. They are the ones that have kept these things going. A thousand thanks.

Kelly

He appreciated the time he spent at Desert Research Institute this past summer. It was a great experience.

\section{Brian Brown, Station Manager and Ken Smith - Shoshone, CA:}

\section{Brian}

There are no outstanding events in Shoshone. The community continues to decline. There is no community attitude toward community monitoring. His elementary school classes, grades 4 through 6 , have gone by the station. There have been no equipment problems. The EPA people are very good. There has been talk about relocating the station somewhere else and that should be done if the program is going to continue. The possibility of adding weather instrumentation would be good. Since he is now teaching at the elementary level and some of the resources are for high school level, he is trying to gear it down for 4th and 5th graders. This last year he did a nuclear science unit. 
Larry Woods, Station Manager and Mark Howard, Alternate - Tonopah, NV:

Larry:

There were no outstanding events. The attitude continues to be that of indifference. He gave a presentation to a Cub Scout group. Mark Howard made a presentation to a family that came by the station. Larry talked to his principal about the 6 th and 7 th graders taking a tour of Yucca Mountain, so they went on tours in January and February. There are no equipment problems. The split sessions were great and hope it will be the same next year. It is a good idea bringing in guest teachers, and possibly consider bringing in Superintendents to maybe get help in funding.

Nate: Two things that have not been mentioned because the people involved are modest. Dale Jensen and Larry Woods received outstanding teacher awards for the year. Daryl Thome' isn't with us, but Herbie, Charlie, Lynn, Flo and Jeff are the guys that make the program function technically. He expressed thanks and appreciation to them from the group.

JoAnne Burrows, Department of Energy:

One of the things she wants them to remember is that their help is needed in getting invitations from community organizations to have presentations given. The topics can be on about any subject. Your help is needed.

Nate: There will be a revised speaker's list going out to each of you. There are two topics to be added, the tree ring studies in Lake Tahoe, recreating climates, and the pack rat midden studies, which also recreates climates from several thousand years of the past.

\section{Bruce Church, Department of Energy:}

He thinks this has been a great program and it has been a great session this year. Mike Slaughter and Byron Hardy did a good job. There were a lot of good instructors this week. From what he had experienced there have been some excellent presentations. He is amazed that after all these years there are still a lot of subject areas that have not even been heard. Talking about next year, there is a whole area of radiobiology that you haven't heard much about. A whole week could be taken in talking about radiobiology plutonium. He was truly flabbergasted Monday when Art Janata said there was nothing new about plutonium. Since the 1950's there is a group of people in the University of Utah that have spent careers studying it. Some of that is what you heard from Ray Lloyd, who has spent his whole career there. The $\mathrm{U}$ of $\mathrm{U}$ is where Bruce started doing his graduate work. There are about five labs around the country that have also done a lot of work on it and there is a lot of information available. Those kinds of speakers could be brought in. We talked a lot in our meeting after the session yesterday about what next year looks like. His advice was to plan like it is going to happen and beyond that he doesn't know.

Back to the suggestions on reports, there is a lot of brain power in this room. If you have good suggestions don't be bashful. It probably doesn't serve any useful purpose if you get up here and say nothing has happened in your community, and kind of walk through that format. But 
he thinks it is useful to get up and talk about the program in some way. Either it is benefiting you or your community, and if it's doing neither then we probably should take our investment somewhere else. We are really anxious to hear your remarks. The DOE management totally supports the program and that is evidenced by those individuals that show up here. Bob Nelson is going to come back next year and take the course for credit.

Nate: Two more people need to be acknowledged, and one is Mr. Church. He has supported this program since its inception, and Dr. Sandquist has been an integral part of this program also.

Gary Sandquist: Bruce Church's comments were very well taken. The best response we have of radiation and nuclear issues and such, is truth and data. So in the training workshop they try to provide scientific basis of it. It is very important that you accomplish both things, that you become very competent and able to understand the measurements and what they mean. It was a very wise Englishman who stated, "Unless you can measure something and give a number to it you don't know very much about it." We were thinking that for the January meeting we need to go and revisit the EPA labs and actually go through some of the steps the resolution of the data is actually taken. You have to be more than just the reader of the data and information and the charts. You really need to understand it so you have confidence in it. The program has lasted a long time. When Bruce first called about the program in the early 1980's, he thought it might be good for a few years, and it has turned out to be very successful. All of you make an important contribution to that. Many of you have been with us for a long time, and some of you are new. He is particularly delighted to have the guest teachers here. The rationale of the time that he devotes to the program is in knowing that as an educator the young people are getting something and that is very important. If we are going to sell the program it probably isn't going to be on continued weapons testing or other areas or even the advancement of nuclear power. However, we do need to educate the children who compete in the world, and nuclear science for whatever basis. It is extremely important, it contributes incredibly to other fields. Nuclear sciences, radiation and other aspects, have contributed in so many ways that the public sort of takes it for granted. Radiation treatment of the food would probably make good sense, because using chemicals and other materials just isn't the viable way to go. The weapons program cost a lot of money, but it provided an incredible amount of knowledge that came into society. Maybe our grandchildren will look back and say that this generation made a lot of mistakes, but overall it was a good thing. They didn't have that confrontation with the Soviet Union that was anticipated. The weapons program was the cheapest way of providing defense for this country.

We are delighted to have you here. We would appreciate your suggestions on the critique sheet about what to do. There are going to be some great changes in this program, unless the program goes away. We may go away and that resource may be lost. Even though Bruce and JoAnne are struggling with their own programs they have been very good about thinking about 
this small piece of the action to which we contribute. If you have any suggestions or thoughts please put them down and we will see you in January, and hopefully see you next fall. 


\section{TRAINING SESSION - SUMMER 1993 \\ Brian Head, Utah August 2-6, 1993 \\ General Comments-Whole Session}

\section{Station Managers and Alternates}

"Educational opportunity here is great-liked the split session"

"Monday was a super day"

"The entire week has been outstanding. I really appreciate the opportunity to participate. I liked the dual session-smaller groups led to good discussion and closer association with the instructor. Thanks very much!"

"I enjoyed the way the training was handled this year. The picnic was great and the family night entertainment and the cookout were great. Thanks."

"Great program."

"Best session we've had, the two simultaneous sessions Tuesday and Wednesday were great! Some very interesting speakers. Fantastic job organizing the session."

"This was a good session. The shift toward hazardous materials and environmental concerns is also timely. I enjoyed the split sessions."

"Bring Dr. Colgate to next summer. Also there was an energy expert that was on "Science Now" 8 or 10 years ago. Talk to Roxanne."

"Liked the split sessions. Food irradiation is a good topic, plus how nuclear weapons are dismantled."

"Split sessions were excellent. I'd like to hear more on meteorology and other related sciences. I recommend that members of news media be invited next year-print and TV-for a discussion session. Also, leave the equipment behind next year. Hotel accommodations here are excellent."

"I liked the mini-class format in the formal instruction portion of the session. It would be interesting to me to visit a reactor site if possible."

"Monday-a super day! Friday-another great day. Best session I've ever attended! Thank you for wonderful accommodations-and great learning experience."

"Split sessions were good"

"I liked the two-track training on Tuesday and Wednesday. Suggestions-more training on support issues like the weather, water/hydrology, education, nuclear basics (for new members/visiting teachers), hazardous material, electrical/nuclear power issues, Yucca Mountain, alternative energy issues, new nuclear developments, i.e., fusion. Enjoyed Brian Head and the activities of the group here." 


\section{Selected Comments about:}

Nick Aquilina

"Always superb"

"Nick should always be given more time-very interesting"

Chris Brown/Norma Cox

"Better informed-or more articulate-than previous speakers"

Mike Slaughter

"Well organized and well done."

"Mike Slaughter is very informative. I appreciated the new information."

Family Night Entertainment

"Well done by those who participated-major non-participation"

Darryl Randerson

"I enjoyed the Citizen's Alert discussion."

Daryl Thome'

"... always interesting to listen to."

Art Janata

"I particularly enjoyed Art Janata."

Station Manager Reports

"Ugh!"

"Shorten/standardize Station Manager reports." 


\title{
EDUCATIONAL OPPORTUNITY \\ FOR TEACHERS
}

\section{ANNUAL SUMMER TRAINING SESSION COMMUNITY RADIATION MONITORING PROGRAM}

\author{
AUGUST 2-6, 1993 \\ BRIAN HEAD HOTEL, BRIAN HEAD, UTAH
}

This is a special opportunity for a select group of high school and junior high school science teachers to join the annual summer training session for teachers and others involved in the Community Radiation Monitoring Program. Sponsored by the Nevada Field Office of the U.S. Department of Energy, this event is planned and directed by Dr. Gary Sandquist of the Nuclear Radiation Laboratory at the University of Utah.

The training covers such subjects as basic nuclear science, radiation, nuclear energy, hazardous and toxic waste management, risk assessment, environmental restoration and related areas. In addition to the chance for broadened educational experience and gain college credit, the training session will provide an opportunity to socialize and interact with your peers in a beautiful setting at a great time of year. Attending the Shakespearean Festival in Cedar City is one of many recreational opportunities. The session is planned and conducted as a family affair-spouses and children are welcome.

A $\$ 500$ stipend to cover travel and expenses will be awarded to the ten teachers selected from Utah, Nevada and immediately adjacent areas of California and Arizona. Approximately 36 hours of participation time are required, and 3 credits can be earned in Nuclear Science from the University of Utah, if desired. A post-session evaluation of the training will be required. This is the second year that this opportunity is being offered, and the response from those who attended in the past was extremely favorable.

If you are interested in applying for this training, please submit a letter of intent on "How Teachers Might Enhance Student Interest in Careers in Science," along with your resume', to:

\author{
CRMP Training Session \\ Attn.: Nate Cooper \\ Desert Research Institute \\ P.O. Box 19040 \\ Las Vegas, Nevada 89132-0040
}

Selection will be based on the following criteria:
a. Background in science
d. Apparent interest in subject
b. Basic concepts on theme
e. Space limitations for enrollment
c. Innovative ideas

Applications must be postmarked no later than April 15, 1993, and all applicants will be notified by May 13, 1993.

Please come join us on the mountain. It's fun, too.

For further information, call Nate Cooper or Juana Blackburn at (702) 895-0455 


\section{TEACHERS ATTENDING THE CRMP SUMMER TRAINING SESSION \\ BRIAN HEAD, UT \\ AUGUST 2-6, 1993}

1. Jan C. Carroll $4486 \mathrm{La}$ Roca Circle Las Vegas, NV 89121

Phone No. (702) 435-1685

2. Jelena Jensen 3311 So. Pioneer St. Holladay, UT 84109

Phone No. (801) 486-9252

3. Sherrie R. Nelson 1966 W. 3875 S. Roy, UT 84067

Phone No.(801) 731-5623

4. Robin L. Parkinson 696 E. $4500 \mathrm{~S}$. South Ogden, UT 84403-3844

Phone No. (801) 479-0876

5. Michael D. Paul 3502 Emerson Dr. Carson City, NV 89706

Phone No. (702) 887-8832

6. Catherine C. Peterson 9603 South Chavez Drive South Jordan, UT 84065

Phone No. (801) 254-1283

7. Chivukula Shyamala 133 South 900 East \#24 Salt Lake City, UT 84102

Phone No. (801) 364-5460

8. Emil Stockton 955 So. $200 \mathrm{~W}$. Heber, UT 84032

Phone No. (801) 654-2712 


\section{Guest Teachers}

"I liked the availability of resources and the willingness everyone showed in sharing knowledge. I had a nice time. Suggestions-information on food preservation, radiation biology."

"Enjoyed the experience-thank you for the opportunity. Scientific interchange and resources were great."

"The radiation monitoring training session was the most informative and pertinent workshop I've attended. The emphasis on the current technological, nuclear and environmental needs of our country is of utmost importance to today's students. I greatly appreciate the opportunity to learn about current events from the experts in the field. Incredible program. Thanks."

"As I understand, this program was presented to teachers from three states and you did not have enough response. I think bringing a couple of speakers for inservice programs at the District level would expose the ideas, and interested people can get further knowledge. I was interested to note that those who presented their concepts were not willing to accept other suggestions or possibilities. I guess in my perspective it would be interesting to see the other side of the argument before I make my decision. Though I did not need anyone to convince me of the nuclear energy. I did see a lot of talk about waste management. I would like to know more about research in waste management. As a "nuclear pro" person, I would like to know more about "Waste Management" so that I can convince the public about "Nuclear Safety." I learned more about the teaching aspects from Station Managers."

"Thank you. I enjoyed the week. I enjoyed listening to people who were obviously enthused about their work and their commitment to making the world a better place. I learned a lot about radiation and feel I am taking home a lot of information I can use in the classroom, especially to use in current issue discussions as well as information I can use to dispel some myths. I would have enjoyed more "hands on" outdoors experiences. For example, going on a hike and releasing a weather balloon, or flying over the NTS, or doing the radiation sweep in the mountains rather than the parking garage. Also, I think more philosophical and ethic questions could have been explored. If the DOE did some entertaining and informative videotapes for classroom use, and perhaps supplied a unit plan for teachers to use and/or modify, it would be great. If a lot of the technical stuff was simplified down to basic principles for students understanding and teachers attending could gear it to grade level, that would be great too.

"The ideas shared by the teachers who had transformed woodshops into tech. labs were valuable. I loved the idea about the portable lab in a mobile home type arrangement. Also, the business partnership sounded terrific. Hopefully these could be implemented in my state (Utah)."

"Thank you for a great week, an intellectual challenge, stimulating and thought-provoking presentations and an opportunity I will recommend to other teachers." 
"This is a very valuable opportunity. Good information in this area is hard to find without sensationalism and bias."

"This has been the most intense and valuable learning experience I have had. I have received more information than I can possibly use in my crammed AP physics courses, but I am looking forward to enhancing and correcting what information I have in my texts. I would love to attend again."

"Some presenters were not conscious enough of their time limit."

"Excellent applicability to personal teaching situations."

"Thanks again to you and the Desert Research Institute for a great experience at Brian Head. I can't think of another week where I've learned so many useful thing."

"I am currently writing a proposal to my administration to start a technology lab for my science teaching. I also plan to contact my district science coordinator and the president of the USTA (Utah Science Teachers Association) to see about presenting some nuclear information at a work shop in October. Thanks again." 


\title{
LAS VEGAS
}

\author{
AUE $1 \cong 1993$ \\ กE:CEIVER

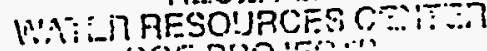 \\ UUEPHODEOT'
}

696 E. 4500 So.

Ogden, Utah 84403

August 16, 1993

Desert Research Institute

Juana Blackburn

P.O. Box 19040

Las Vegas, NV 89132-0040

Dear Juana

Thanks again to you and the Desert Research Institute for a great experience at Brian Head. I can't think of another week were I've learned so many useful things.

I am currently writing a proposal to my administration to start a technology lab for my science teaching. I also plan to contact my district science coordinator and the president of the USTA (Utah Science Teachers Association) to see about presenting some nuclear information at a work shop in October.

Thanks again.

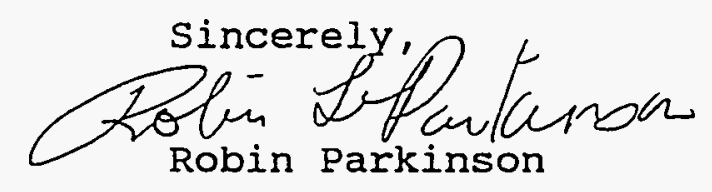




\section{APPENDIX B}

Documentation of Outreach Efforts 
September 1.8. 1992

LAS VEGAS

To: Nate Cooper

OCT 271992

RECEIVED

WATER RESOUROJECTS

Fram: Don Curry

Re: Global Lab Project, Val iev rigr Schooi

As you recall from our conversation of last week, I wrote $a$ proposal this past May seekirig participation in an international environmental sciences project and was sussequentlv seiected as one of approximately ninety igo; putlic Echools representing fifteen (15) countries to be involved in the croject. It is funded by the National Science Foundation ano is jesignated as the "Global Laboratory Project". The stateo gaals are:

* To develop curriculum ijeas that wi: suild stujent science skillj wlthin the context of global eculogy arid climate change, and then integrate these iceas into the science classroom.

* To build an international network of students. teachers, and scientists who wlll collaborate in research, experimentation and curriculum development.

* To develop inexpensive instruments for environmental monitoring, as well as softwar and data analysis.

As students monitor local sites, it is our hope that they will besin to think on a more "global" level and will view their data in a regional and/or world cantext. In doing so, our expectations focus on the acquisition of a set of skilis that will serve them in their roles as potential scientists and, most definitely, as that of informed citizens.

This Glotal Lat Project is part of an effort to understand and expand the role of technologies in mathematics and science education. GLP's parent group is a twenty-seven (27) year-old non-profit educational research and development organization dedicated to improving science and mathematics learning for all students at all grade ievels. This particular project refresents the confluence of three interrelated streams of research and development: project-based learning, microcomputer-based laboratories, and computer-based telecommunications.

A significant soal is that of telecomputing to support international student and teacher collatoration. iurrent efforts aim to design and distribute "user-friendly" software that will enhance the exchange of data, maps, graphics, etc., throughout the world. 
The ultimate goai, as you nijnt juess, =s sinfly to zimpro.e the quality of education at the iocai ievel. This means, of zourse, that the project is open-endeg. may actualiy have some "dead ends" and will, hapefully. zientify rew deas and technolagles that zan be successfuily implemented in the alassroum ay the ano of the funding period in 1995.

This consartium of stujents, ieachers ard scientisis from around the world will collaborate to ennance jecondar; sclence education. The students will seiect iocal stusy sites and examine their environmental conditions over the school year. In doing so, the students wili be encouraged to view the "real world", develup research ideas, design $\&$ conduct investigations, analyze their own data and consider possible remedia? actions. The project does anticipate a broadening of students' perspectives by using telecommunications to link classrooms with each other and with the scientific community.

At the end of the academic rear, students wil: pubi:sh a Global Lat Journal. Peer review and publication are important. as they underline the need for communications in science ano motivate thoughtfulness. Through them, students internalize scientific attitudes of skepticism and integrity.

One of the advantages, Nate, is that this project emphasizes an interdisciplinary approach. You and I both know that "science" is NOT a discipline unto itself, but it seems that this has been the traditional organizatian of science instruction at the public school level. Departure from this traditional view represents a quantum leap, to me, In movirig toward a better unuerstanding of the "interrelatedness" of many academic disciplines. I personally believe that this is cruciai for our students to see, to feel and to acknowledge.

A number of individual "low-cost, high-tech" instruments have been developed for use in this project and are made avallable via TERC, the project's parent agency. I've attached copies of materials recently received that detail some of these instruments and how they can be used in our field studies.

I'm sure this doesn't answer a'll your questions, so perhaps we can get together soon over a cup of coffee and discuss where we go from here!

Thanks for taking time to read over this! I think it will be a very exciting and rewarding program for our students, as well as our community at 1 arge.

I hope to talk to you soon,<smiles>CCCCCCCCCCCCCCOCC</smiles>

Don M. Curry, Chairperson

Science Department

Valley High School 
Desert Research Institute

P.O. Box 19040

Las Vegas, Nevada 89132-0040

Dear Mr. Cooper:

This letter is to update you on opportunities that have come to me to share the information obtained at the Community Radiation Monitoring Program Training Session last summer.

As school started I shared the workbooks and much of the information on nuclear energy with my co-teachers at the Springville Middle School. In September I was appointed to the Mt. Nebo District Science Curriculum Committee. On this committee I have the opportunity to incorporate Nuclear Energy Education into the State Core Curriculum.

At the Utah Science Teachers annual convention in October I was elected to represent the Utah Middle School Science Teachers. One of my responsibilities in this capacity is to help plan the Mid-Winter Institute for all the science teachers in Utah. Because of my experience at your training session I immediately called your office to arrange a workshop presentation by your organization.

My experience confirms that your decision to include teachers in your training session will greatly multiply nuclear education in our schools. I hope that there will be more opportunities to include teachers in your future training sessions and other programs.

Thank you for your help - your staff has been delightful to work with.

Very Truly Yours,

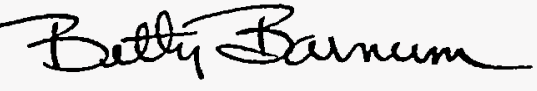

Betty Barnum 
UNITED STATES ENVIRONMENTAL PROTECTION AGENCY

OFFICE OF RESEARCH AND DEVELOPMENT

ENVIRONMENTAL MONITORING SYSTEMS LABORATORY-LAS VEGAS

LAS VEGAS

JAN 261993

WA-T RECEIVED

WATER RESOURCES CEN:T'ER

DOEPROUECTS

\section{MEMORANDUM}

SUBJECT: Deer Presentation

FROM:

Kenneth R. Giles

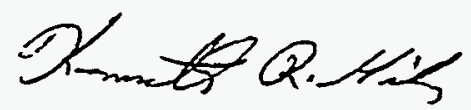

TO:

George G. Martin

Chief, NRO

On January 16, 1993 I gave a presentation on the Deer Migration Study to 20 members of the Preceptor Iota Chapter of Beta Sigma Phi in Henderson, NV.

cC: Nathan cooper, DRI

Paul Weeden, NRD

Daryl Thome', NRD

Herbert Maunu, NRO 


\title{
Department of Energy
}

Washington, DC 20585

January 26, 1993

\author{
LAS VEGAS \\ FEB 11993 \\ WATER RESEIVED \\ DOEPROJECTS CENTER
}

Nate Cooper

Desert Research Institute

P.0. Box 19040

Las Vegas, NV 89132-0040

Dear Nattebofe

Thank you for taking time out of your busy schedule to give the presentation on the NTS Community Radiation Monitoring Program at the recent EM public participation workshop in Las Vegas. The presentation was informative and interesting, and it generated lots of questions. It's always encouraging to hear about successful community involvement programs.

We also appreciated your effort to dress for the occasion. Thanks for your participation.

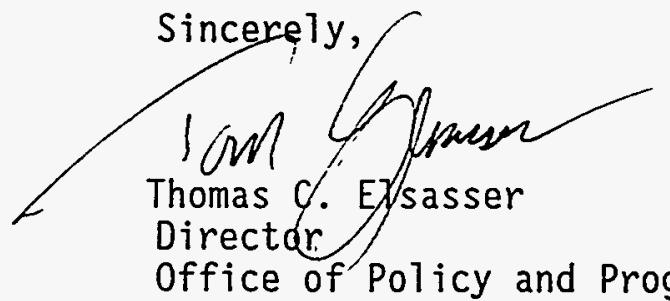

Office of Policy and Program Information

Environmental Restoration and Waste Management

cc: Darwin Morgan 


\section{Radiological Environmental Assessment Group University of Cincinnati}

LAS VEGAS

APR 221993

RECEIVED

WATER AESOURCES C

DOEPROJECIU

April 16, 1993

Community Radiation Monitoring Program

Station Managers and Alternate Managers

Dear Sir or Madam:

The University of Cincinnati is providing support to the Nevada Operations Office of the Department of Energy for the environmental restoration of the Nevada Test Site. Included in our scope of work is a determination of activity patterns typical of the areas around the test site. The University of Cincinnati has been actively working with the Desert Research Institute (DRD) in Las Vegas to gather the needed information.

An important aspect of the information that we do not yet have is the food consumption habits specific to your areas. There are statistics available reflecting the national average values for this data, but our work would benefit from obtaining area specific information. With the concurrence of Nate Cooper of DRI, I have prepared a two page survey which I am asking you to complete and return to me. Participants in the Community Radiation Monitoring Program were chosen for .this initial survey because of your familiarity with activities of the DOE and DRI and because your location in the communities around the test site.

The goal of the survey is to establish the food consumption patterns of individuals residing in your areas, and gather additional information regarding activity patterns. I realize that it may be a bit difficult to answer the questions, but please give it an honest effort. Some of the questions pertain to livestock; answer these if you are able. I would like to receive your response by the end of May if possible. Thank you very much for your help in this matter.

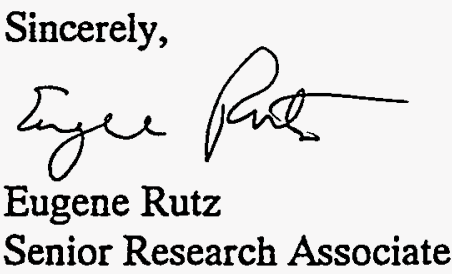

enclosures: Instructions

Food Consumption Survey

c. Nate Cooper DRI

Roy Eckart, UC 


\section{Radiological Environmental Assessment Group \\ University of Cincinnati}

\section{INSTRUCTIONS FOR COMPLETING THE SURVEY}

The goal of the survey is essentially to establish the food consumption habits of individuals living in areas around the Nevada Test Site. Additional questions are asked concerning amounts of time spent indoors and outdoors. The objective of the food consumption survey is to determine the average amount eaten per year of certain foods, such as red meat, milk, and fish. The most useful format for this data would be in pounds eaten per year. We recognize that this is difficult to estimate. Several possible ways of answering the questions are: 1) amount (pounds) eaten in an average day, week, or month, 2) number and approximate size of servings eaten in an average day or week, or 3) recording the weights of food purchased at the store and estimating the length of time over which they were consumed (for example, purchased $2.5 \mathrm{lbs}$ of beef and $1 \mathrm{lb}$ of fish which were eaten in 4 days).

Other questions on the survey deal with livestock. If you keep livestock, or are familiar with raising livestock, please complete these questions. Otherwise, you may simply leave these items blank, or ask someone in your area who does raise livestock.

Once you have completed the forms, please return them to

Eugene Rutz

University of Cincinnati

Cincinnati, $\mathrm{OH} 45221-0072$

I would like to receive the completed surveys by the end of May if possible. Thank you for helping us with this matter. 


\section{Activities / Food Consumption Survey}

\section{Activity Patterns}

Please indicate as best you can the average number of hours per day you spend in the following types of activities:

Heavy labor (farm, gardening, industrial, etc.)

Light activity (walking, household chores, etc.)

Resting (reading, watching TV, etc.)

Sleeping

Average number of hours per day spent outdoors at home

Average number of hours per day spent indoors at home

Average number of hours per day spent indoors away from home (work, shopping)

Average number of hours per day spent outdoors away from home

Average number of days per year away from home

\section{Food Consumption}

List the foods commonly eaten (what foods would you eat in an average week) 
Food Consumption

List the amount eaten (by weight if possible or by number of servings) of the following foods (you can list either an average amount per day or total amount eaten in a week)

meat (beef, poultry, pork)

milk

leafy vegetables (lettuce, spinach, etc.)

fruits and non-leafy vegetables

grains (bread, pasta, cereal, etc.)

fish

shellfish

local game

If you have a garden, what percentage of a yearly total of the following foods do you grow at home?

leafy vegetables

fruits and non-leafy vegetables

grains

If you keep cattle or chickens for personal consumption what percentage of a yearly total do they provide?

beef

pork

poultry

milk (from cow or goat)

If you keep cattle please estimate the following:

Average weight of beef cattle Average weight of dairy cow percent of year grazing percent of year on stored feed total consumption of stored feed (grain or hay) age of cattle at time of slaughter 


\title{
FALLOUT IN TONOPAH, NEVADA PAST and PRESENT
}

\author{
Presented By: \\ DAVID L. WHEELER
}

U.S. Department of Energy

APRIL 26, 1994 


\section{FALLOUT IN TONOPAH PAST and PRESENT}

- Atmospheric Testing of Nuclear Devices Created Fallout in Downwind Areas Such as Tonopah 


\section{ATMOSPHERIC TESTING OF NUCLEAR DEVICES CREATED FALLOUT IN DOWNWIND LOCATIONS SUCH AS TONOPAH}

- NTS Atmospheric Test 1951-1958 Resulted in 0.2 Percent of Total Yield Worldwide

- Downwind Fallout Characterized by Radiation Monitoring Instruments Deployed Downwind

- Cumulative Exposure Maps Prepared for Off-Site Personnel Protection According to Existing Guidelines 


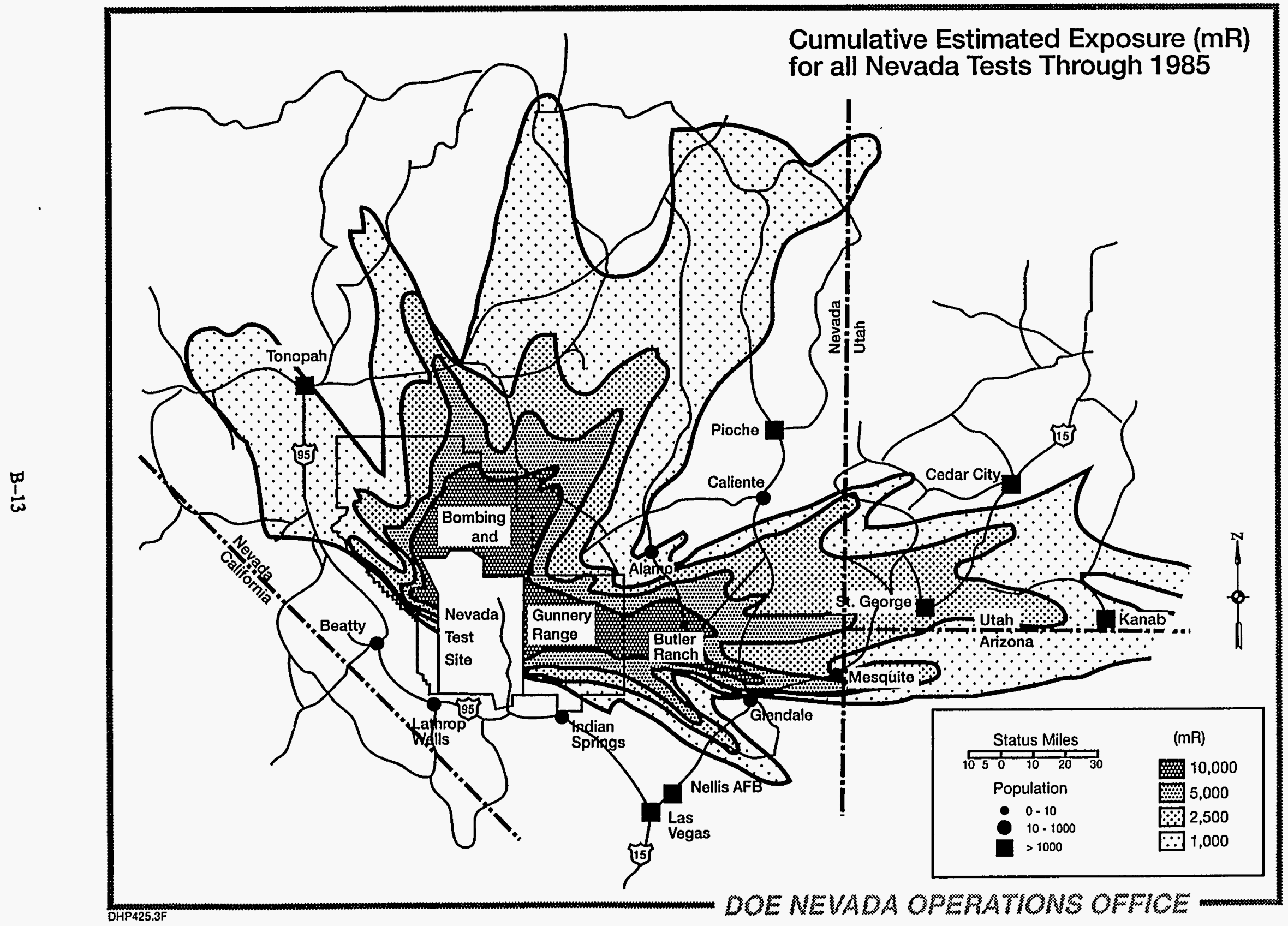




\section{FALLOUT IN TONOPAH PAST and PRESENT}

- Atmospheric Testing of Nuclear Devices Created Fallout in Downwind Areas Such as Tonopah

- Off-Site Radiation Exposure Review Project (ORERP) Has Evaluated Downwind Radiological Situation 


\section{OFF-SITE RADIATION EXPOSURE REVIEW PROJECT (ORERP) HAS EVALUATED THE DOWNWIND RADIOLOGICAL SITUATION}

- Historical Records Reviewed and Applied to Modern Dose Reconstruction Technology

- Modern Techniques Developed to Determine Fallout That Occurred 30 Years Ago 40

- Reconstruction Doses Compare Favorably With Original Estimates 


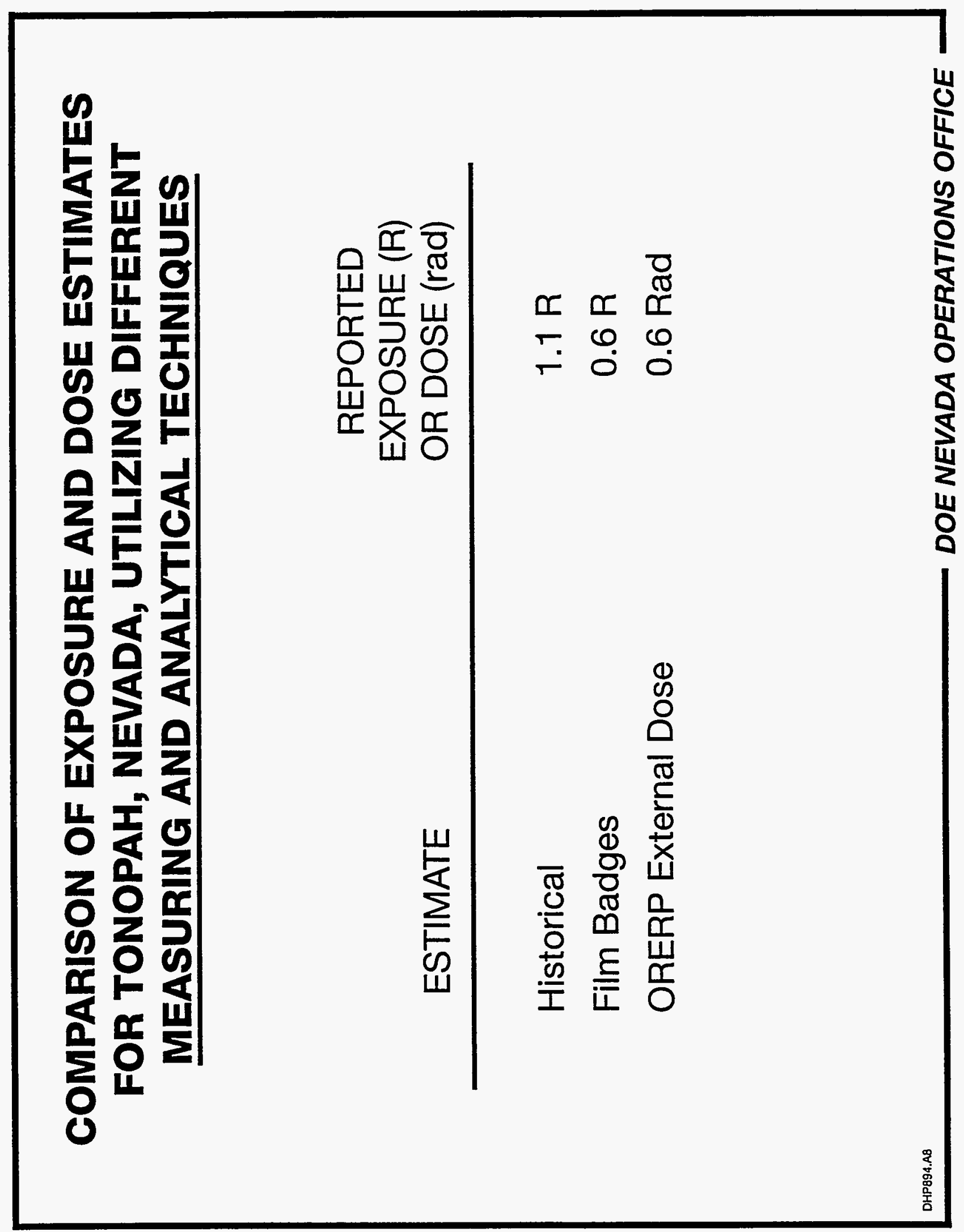




\section{FALLOUT IN TONOPAH PAST and PRESENT}

- Atmospheric Testing of Nuclear Devices Created Fallout in Downwind Areas Such as Tonopah

- Off-Site Radiation Exposure Review Project (ORERP) Has Evaluated Downwind Radiological Situation

- Underground Testing Since 1961 Has Resulted in Minimal Impact to Off-Site 


\section{UNDERGROUND TESTING SINCE 1961 HAS RESULTED IN MINIMAL IMPACT TO OFF SITE}

- Of 806 Underground Test at the NTS Designed to be Contained, Only 31 Have had Accidental Releases Detected Off Site

- EPA Maintains Radiological Monitoring Program Off Site

- Community Radiation Monitoring Program Provides Public Interface With Government Agencies 


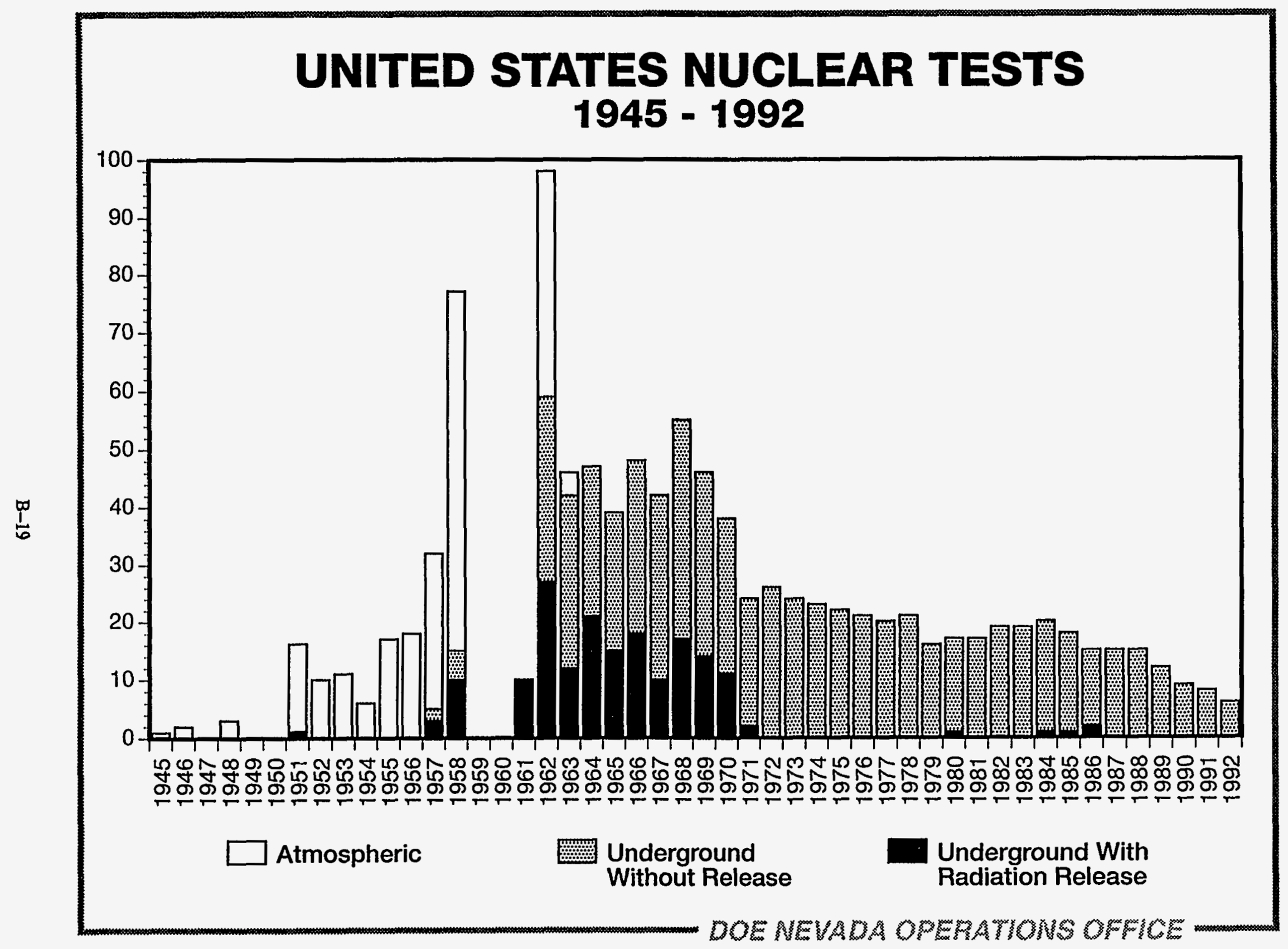




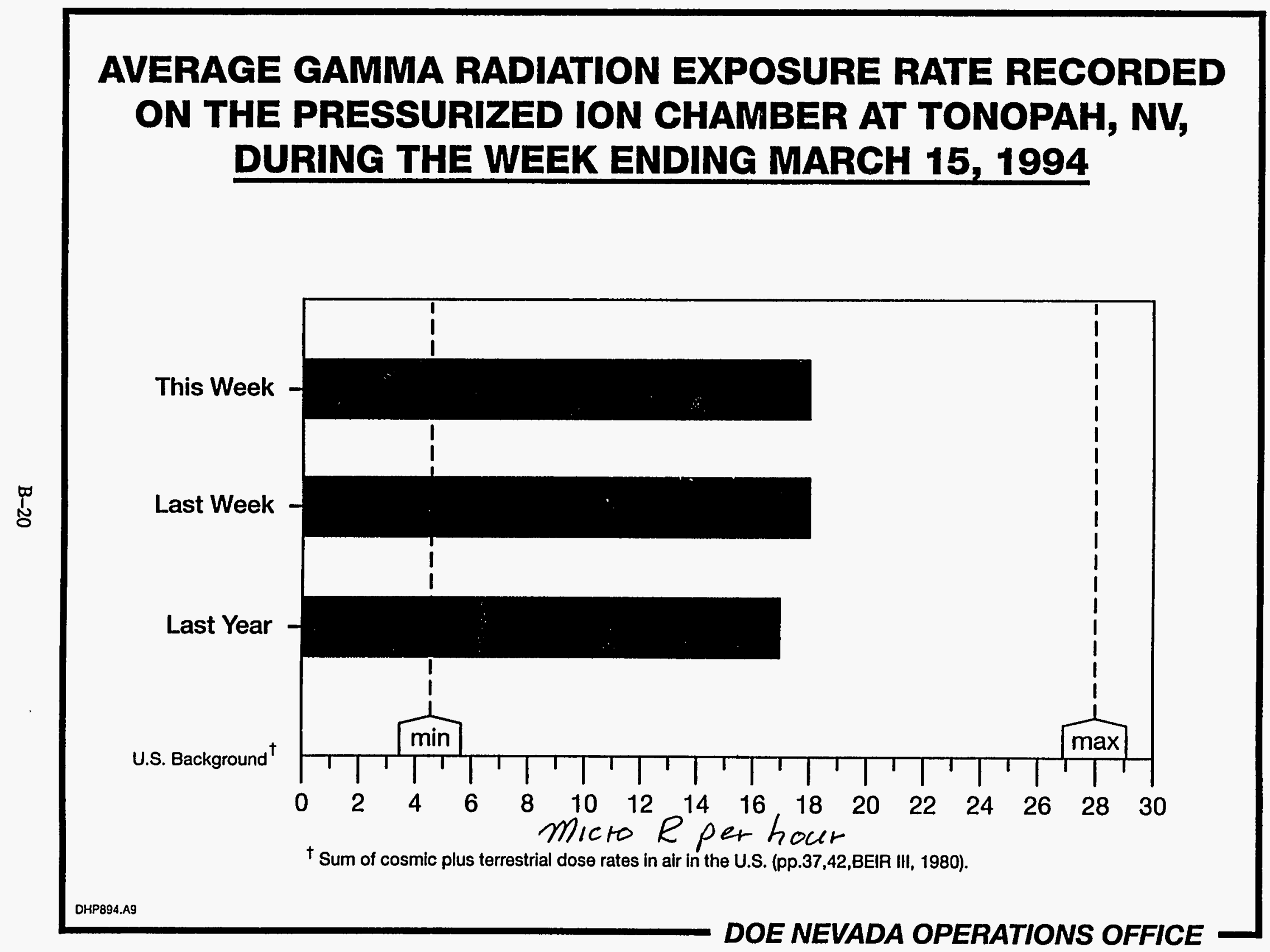




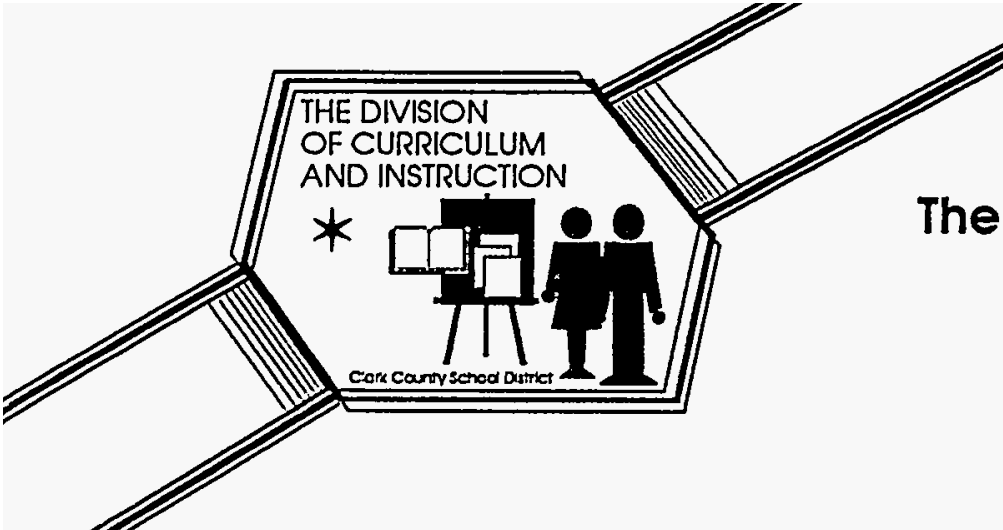

\section{Clark County School District The Division Of Curriculum And Instruction}

601 North Ninth Street

Las Vegas, NV 89101

(702) $799-8400$ / Fax 799-8460

May 7, 1993

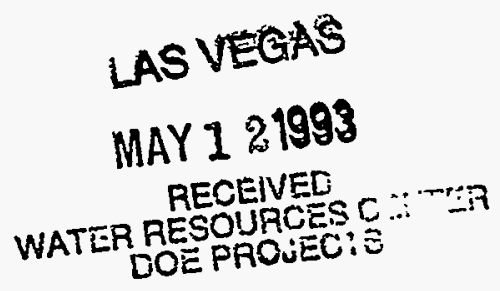

Nate Cooper

Educational Programs Manager

Desert Research Institute

Las Vegas, NV 89119

Dear Nate:

This is a follow-up to our earlier discussion about DRI's participation in the Summer Institute for Mathematics and Science teachers (SIMS). Our goal is to provide the participants, 46 teachers from 23 junior high $/$ middle schools, with knowledge and skills to encourage women, minorities, and other underrepresented groups to continue their education in science and mathematics. A Direct knowledge of job opportunities which employ these fields, as well as knowledge of what these jobs entail, is an important aspect of achieving this goal.

I have tentatively scheduled a tour of the DRI facilities and small group interactions with scientists and mathematicians based on our earlier discussion. Of course, this is only a suggestion; if you have other suggestions on getting our group to DRI, our program is flexible at this point. However, we would like to finalize the program as soon as possible in order to get the information to the participants before school is out.

I am enclosing a draft of our tentative schedule so you can get a sense of the entire program. Please let me or Ruth Wilson know if the proposed tour of DRI can be confirmed, or if you have other suggestions. We can be reached at 799-8437 or 799-8436.

Sincerely,

Gene Butler

Science Curriculum Specialist

$\mathrm{mt}$

cc: Ruth Wilson

Attachment 
MONDAY JULY 12

\author{
SIMS SCHEDULE \\ JOHNSON JUNIOR HIGH \\ 7701 Ducharme Av \\ Las Vegas, NV 89128
}

7:30 INTRODUCTIONS/PURPOSE OF WORKSHOP

GENE BUTLER \& RUTH WILSON

7:45 OPENING REMARKS NICK AQUILINA

U.S. DEPARTMENT OF ENERGY

NEVADA OPERATIONS OFFICE

8:00

WORKFORCE 2000 ANN MUELLER

AFFIRMATIVE ACTION OFFICER

DESERT RESEARCH INSTITUTE

9:00 GENDER AND CULTURAL ISSUES

E. LAVONNE LEWIS

HUMAN RESOURCES DEPARTMENT MANAGER REYNOLDS ELECTRICAL \& ENGINEERING CO., INC.

10:00 BREAK

10:15 LEARNING STYLES CONNIE KRATKY

11:30-12:30 LUNCH ON YOUR OWN

12:30 LEARNING STYLES CONNIE KRATKY (CONTINUED)

2:00 DAILY WRAP-UP AND ADJOURNMENT

TUESDAY JULY 13

7:30 -8:30 NCTM/PROJECT 2061/SSC RUTH AND GENE

8:30-11:30 ENVIRONMENTAL ACTIVITIES/MATH-SCIENCE CAMP JHONE EBERT GVHS

11:30-12:30 LUNCH ON YOUR OWN 
12:30 GENE MCGAUGH, DIRECTOR, MINORITY ENGINEERING PROGRAM. LOCAL AND NATIONAL RESOURCES FOR ENCOURAGING WOMEN AND MINORITIES TO REMAIN IN MATHEMATICS AND SCIENCE

2:00 DAILY WRAP-UP AND ADJOURNMENT

WEDNESDAY JULY 14

(MEET AT DRI)

7:30 TOUR DESERT RESEARCH INSTITUTE. THREE GROUPS, ONE TOURING, OTHER TWO GROUPS MEETWITH DRI SCIENTISTS ANND MATHEMIATICIANS. ROTATE UNTIL ALL THREE GROUPS HAVE BEEN THROUGH THE ROTATION.

11:30 COMPLETE TOUR LUNCH ON YOUR OWN

12:30 EQUALS OR ENVIRONMENTAL SLEUTHING

2:00 DAILY WRAP UP

THURSDAY JULY 15

7:30 TOUR DOE/EG\&G IMAGE PROCESSING CENTER

11:30 RETURN FROM TOUR LUNCH ON YOUR OWN

12:30 TECHNOLOGY FOR THE CLASSROOM

2:30 DAILY WRAP-UP AND ADJOURNMENT

FRIDAY JULY 16

7:30 FAMILY MATH/FAMILY SCIENCE

10:30 SCHOOL TEAMS PLANNING 
July 28,1993

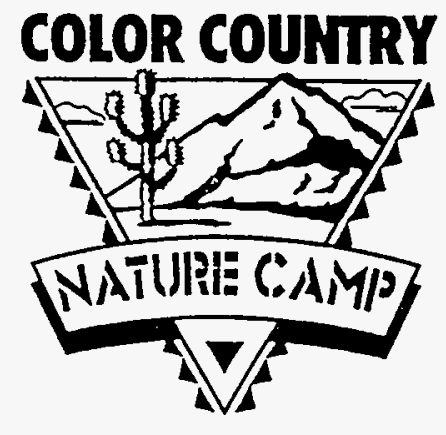

Nate Cooper

Desert Research Institute

P.O.Box 19040

Las Vegas, Nevada 89132-0040

Dear Nate:

"There are just two things on this material earth - people and natural resources."

Gifford Pinchot

Thank you for your participation as a representative of the Desert Research Institute in Utah's first natural resouce camp. Without dedicated conservationists like you Color Country Nature Camp could not have become a reality. As you may have heard, the camp was a big success. I have enclosed your copy of the Memo of Understanding for the camp as well as a recent article which appeared in the Daily Spectrum.

Special thanks to John Doherty for his participation in the Color Country Nature Camp Career Fair. It was one of the highlights of the week according to the students involved. We are hoping that this camp will become an annual event. We look forward to continuing to work with you on future camps.

Sincerely,

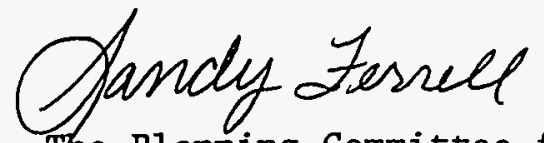

The Planning Committee for Color Country Nature Camp 
LAS VEGAS

AUG1:1993 Rey.10, 1983

WAT-RBESOUROE

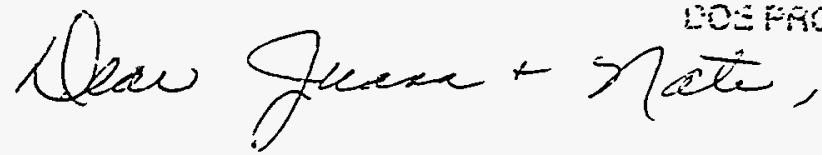

- Hente you so muci jos a tesige.

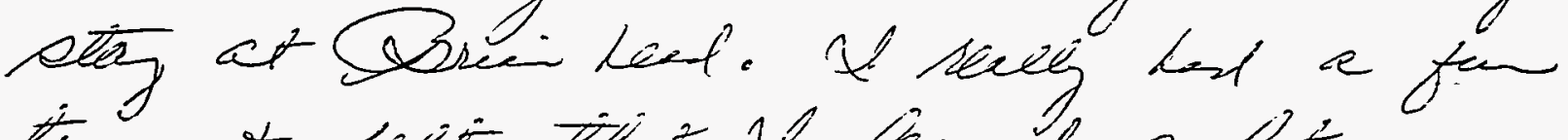

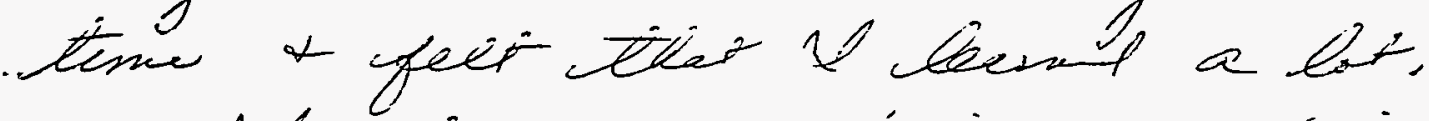

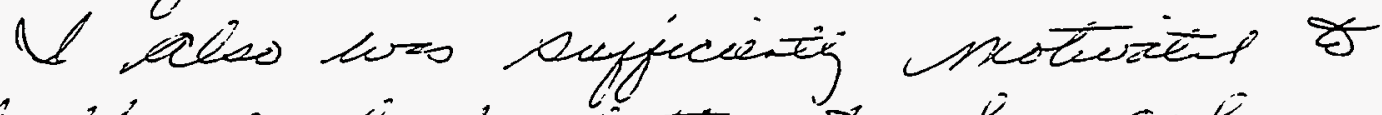

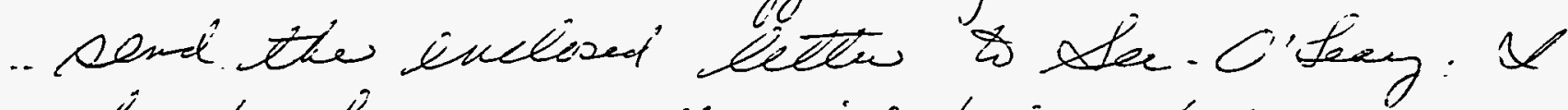

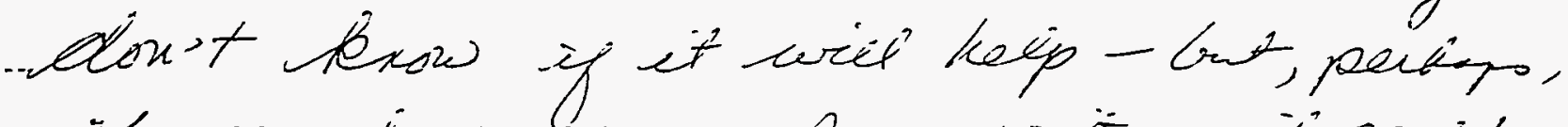

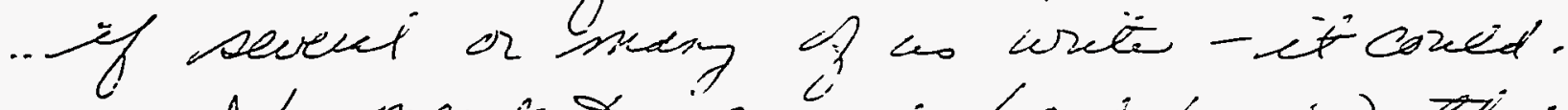
$\checkmark$ meant to "suggat (al forgot) Xi-

- you sevetery sne Copies of the Detaton.

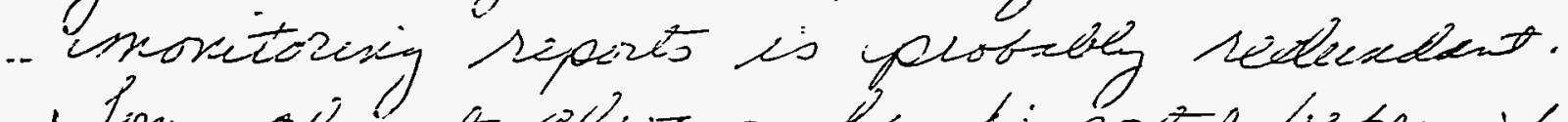

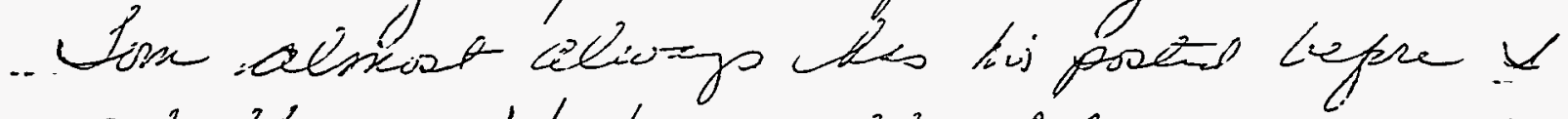

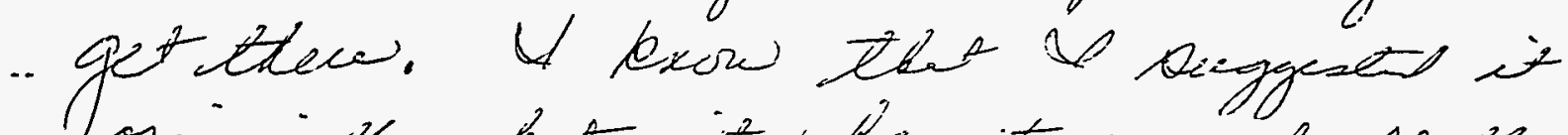

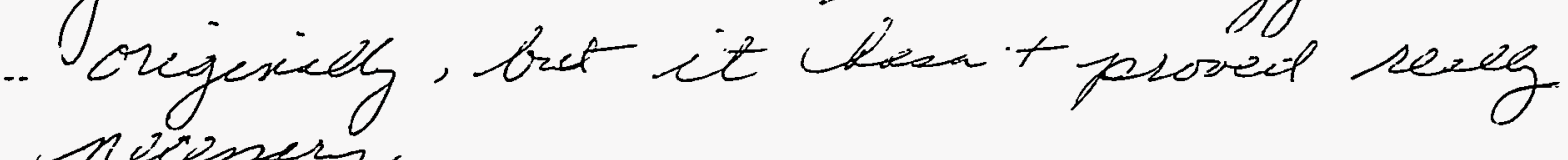

neiessery.

'Pgari, thask fir evength:;

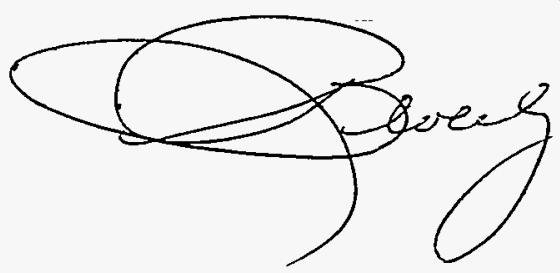

B-25 
August 9,1993

Secretary Hazel O'Leary

U. S. Department of Energy

1000 Independence Avenue NW

Washington, D.C. 20585

Dear Secretary O'Leary:

I am very well pleased with your appointment as secretary of the DOE. From people, who have met you or worked with you, I have heard praise of your ability to work well with others, your administrative capabilities, and your knowledge and background in the energy field.

I am concerined, however, about the fact that, thus far, an Undersecretary of Nuclear Energy has not been appointed. I hope this is not an indication that the DOE and the Clinton administration are trying to phase out nuclear capacity and research in our country.

Considering that we are currently dependent upon nuclear energy for approximately $20 \%$ of our electricity, and that scientists estimate, with a great deal of confidence, that our sources of fossil fuel will be virtually gone within 50 years, it seems foolhardy for the United Siates to fail to maintain the physical and mental capability of constructing additional nuclear power plants, or to cease research and development in other nuclear fields.

As an active Democrat (admittedly swimming uphill in Utah), I would hate for the first Democratic Administration in over a decade to be responsible for the demise of nuclear capability in the United States.

I appreciate the help the DOE has been in assisting universities with nuclear reactors, and hope it will continue to do so. As a public school teacher, I recognize that the education, which these universities provide, is the very basis of our maintaining any capability in the nuclear field-rather than becoming dependent on countries such as Japan, Erance or Canada for expertise.

I wanted you to be aware that there are large segments of the public, who have studied the issues sufficiently, that are not irrational1y paranoid about nuclear "everything," and consider it a necessary component of our energy production. I hope you feel the same way.

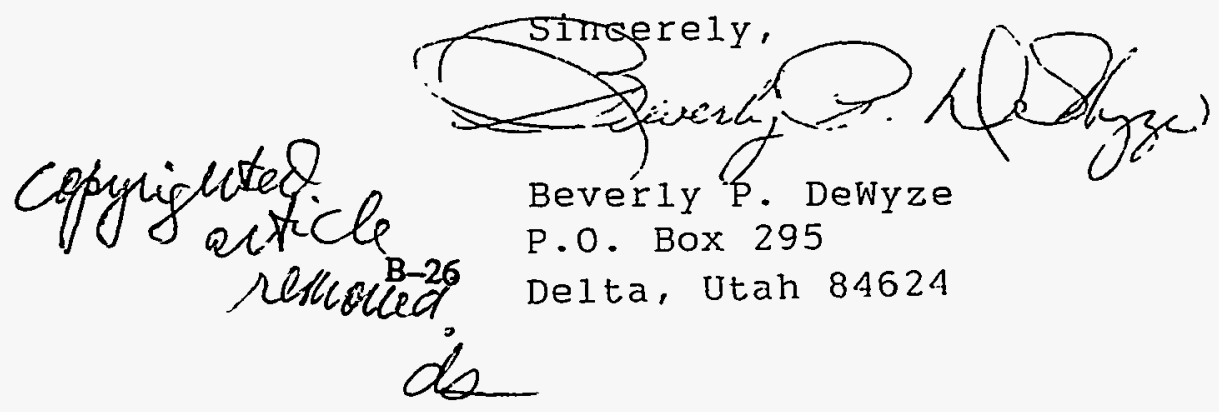


KEITH KOERNER

Principal

\section{Beatty High School}

P.O. Box 806

Beatty, Nevada $89003-0806$

Phone 553-2595

FAX 553-2646

May 20,1993

Mr. Nate Cooper

Desert Research Institute

755 East Flamingo Road

P.O. Box 19040

Las Vegas, NV 89132-0040

Dear Mr. Cooper:

We would like to thank you for the long term loan of the dual trace oscilloscope. With the rising costs and the cuts in our budgets, items such as this are impossible for us to purchase.

It is through institutions such as yours and people such as yourself that allow our students to be able to use such equipment. Without your help our science students would not be able to use even a sampling of the technology that is available in the scientific world today.

Again thank you for your help.

Sincerely,<smiles>CCCCCCCCCCCCCCCC(C)(C)C(C)(C)C</smiles>

Keith Koerner

Principal
ROBERT W. RAGAR

Superintendent
LAS VEGAS

MAY $2 \& 1993$

RECEIVED

WATER RESOURCES CEN:TEA 


\section{APPENDIX C}

Rocky Flats Plant Community Radiation (ComRad)

Monitoring Program 
Nate Cooper

Desert Research Institute

Water Resources Center

P. O. Box 19040

Las Vegas, Nevada 89132-0040

Dear Nate,

Thank you and Juana Blackburn for supporting the Rocky Flats Plant (RFP) Community Radiation (ComRad) Monitoring Program station managers' annual training session. Bob Nininger and I appreciated your effort in the organization of the Brian Head training session and extending an invitation to the RFP ComRad program teachers.

The RFP station managers and alternate station managers stated they preferred the format of this year's training session. The idea that they could choose between environmental and radiation topics gave them the opportunity to train in the area where they felt the most need. Also, I heard several good comments from the station managers on the rotation of presenters; the different teaching styles provided diversity in the manner that the material was being presented.

The station managers enjoyed the variety of speakers on Monday. Since Bob Nelson initiated the RFP ComRad Program, he was their favorite speaker; however, they were highly interested in the Teacher Research Associates (TRAC) presentation as well as the Educational Outreach presentation. Overall, the station managers praised the training that they received at Brian Head.

Thank you again for your graciousness and hospitality as well as the professionalism extended to the RFP station managers, alternate station managers, and RFP personnel. I look forward to future interactions with you and Juana with the Community Radiation Monitoring programs.

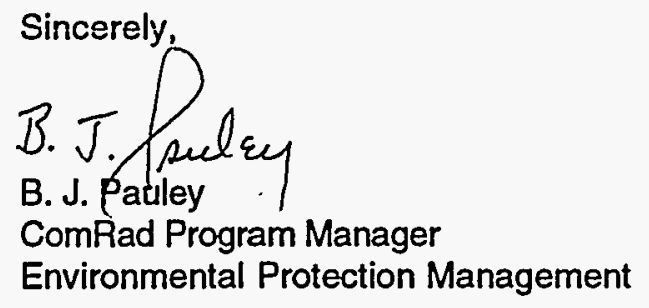




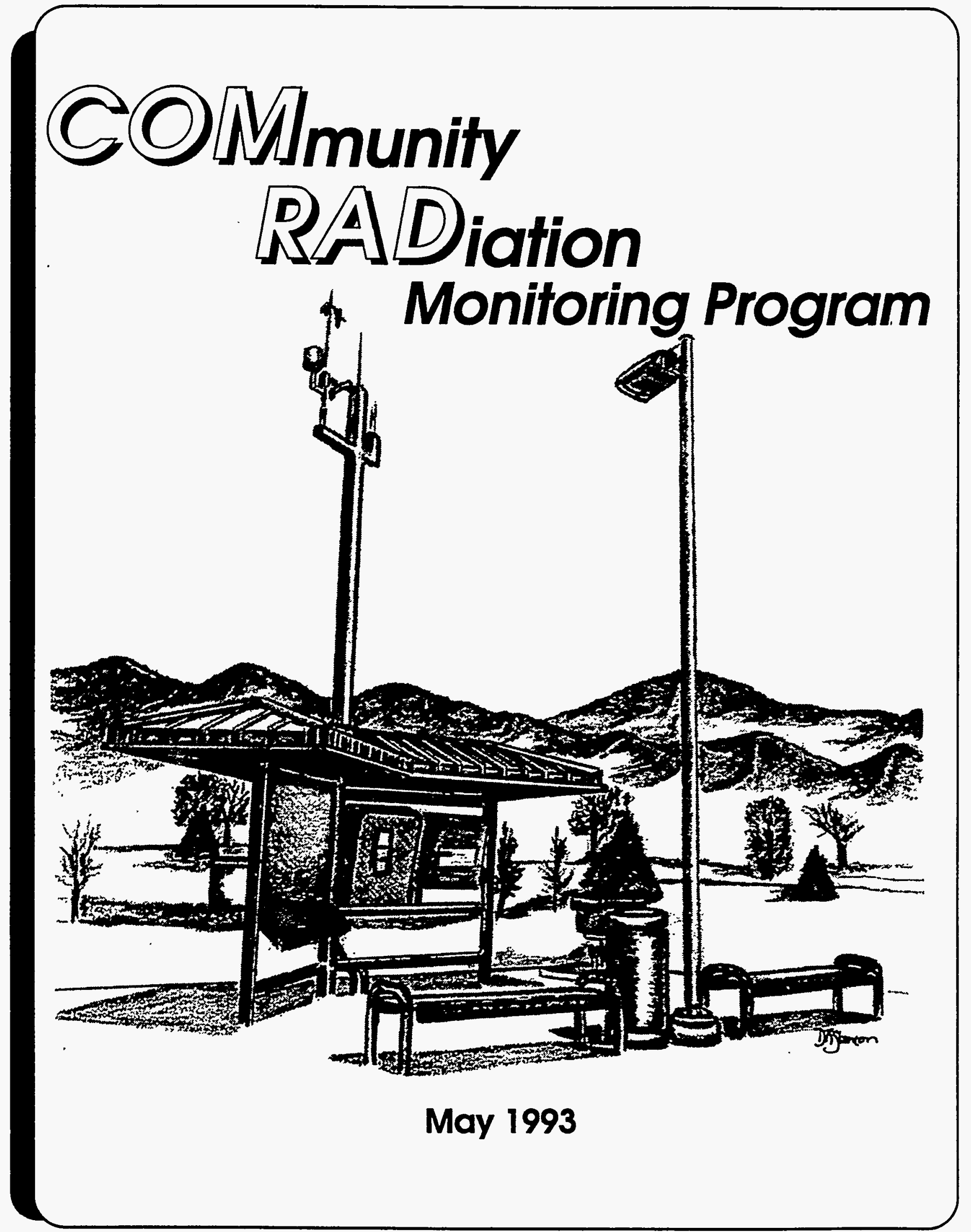

C-2 


\section{Contents}

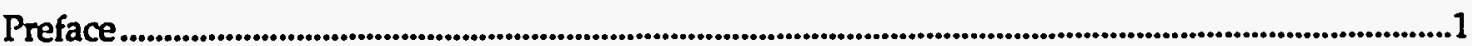

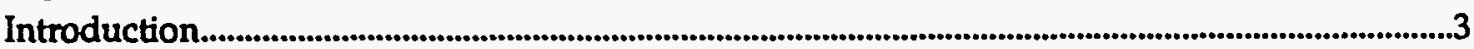

Introduction to Station Managers and Alternate Station Managers..................................................5

Station Managers and Alternate Station Managers........................................................................................12

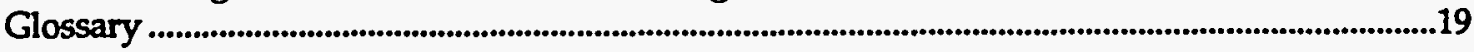

\section{List of Tables}

Table 1 Standley Lake Library Ambient Air Monitoring Station..............................................9

Table 2 Standley Lake Library Weather and External Gamma Radiation Data .....................10

Table 3 Environmental Thermoluminescent

Dosimeter Measurements ......................................................................................................11

\section{List of Figures}

Figure 1 Monitoring Station Locations .......................................................................................13

Figure 2 Gamma Radiation Detector ...........................................................................................14

Figure 3 Weather Station .................................................................................................................15

Figure 4 Weather Station Panel..........................................................................................................16

Figure 5 Ambient Air Sampler ........................................................................................................17

Figure 6 Thermoluminescent Dosimeter ...................................................................................18

\section{Appendix}

Appendix A Distribution ..............................................................................................................25 


\section{Community Radiation}

Moniforing Program 


\section{Preface}

As of June 1, 1993, all five Rocky Flats Plant (RFP)

Community Radiation Monitoring stations are operational and will be collecting data for reporting (June ComRad Monthly report). In this issue, RFP would like to introduce the 10 local teachers who are serving the public as station managers and alternate station managers.

Each ComRad site employs a station manager and an alternate station manager to operate the equipment, collect data and samples, prepare and submit the samples to a designated laboratory, and report the resuits to the public.

Operation of the ComRad stations require a commitment of time and interest from all involved. Candidates who applied for the position of station manager or alternate station manager had to be willing to commit the time and effort required to successfully operate a station. The selection criteria included the following considerations: residency - first preference was given to individuals who live and work in the community; occupation - first preference was given to active educators; educational background - candidates with a college or university degree in a science related field were given first preference; recommendations - letters of recommendations from local school officials, civic leaders, or other individuals; community integration - applicants were asked how they expected to utilize their participation in the ComRad Program in their work environment and in the local community; public interaction - applicants must be able to speak at public gatherings and work effectively with diverse public interest groups; and physical requirements - applicants must be physically able to perform all duties associated with operating the ComRad station.

The station manager and alternate station manager act as liaison between their community and RFP. They call or assist in arrangements for town meetings to inform the local communities about radiation surveillance, safety, and concerns expressed by citizens who attend the meetings.

RFP is proud of the station managers and alternate station managers who were selected to serve the communities. Ninety-six application forms for the positions were submitted to area schools and governments. 
Of all the applications, RFP selected 10 most qualified teachers to serve the local community.

Each station manager and alternate station manager has been provided with a private telephone line and answering service. Their telephone number is listed on the bulletin board at each station, as well as in the ComRad Monthly report. Please call your station manager and alternate station manager not only to answer your questions, but to let them know you support them and the ComRad Program. 


\section{Introduction}

The Rocky Flats Plant (RFP) Community Radiation Monitoring (ComRad) program is a cooperative effort of the Department of Energy (DOE), EG\&G Rocky Flats, Inc., and the communities surrounding the RFP. ComRad involves citizen-operated environmental air surveillance stations, the locations of which are shown in Figure 1, page 13.

The purpose of ComRad is to provide a mechanism for individuals living in the surrounding area to actively participate in the RFP environmental surveillance program, increase public awareness of the program, and improve communication with local communities.

Each ComRad station consists of equipment to sample the air and measure environmental radiation exposure. The stations are designed to sample for the following radioactive materials: airborne, alpha-emitting particulates; and ambient, external penetrating gamma radiation. The equipment also measures air temperature, barometric pressure, humidity, wind speed and direction, and rainfall. Samples are analyzed at a designated laboratory, and pertinent data are recorded by the station manager at defined intervals. The equipment selected is reliable, relatively maintenance free, and has low detection limits and low operating costs. A panel of community technical representatives and other individuals selected the following types of monitoring equipment to be located at each station.

1. Gamma Detector - measures the exposure rate of penetrating gamma radiation in the area surrounding the station. Background gamma radiation is measured in micro-Roentgens per hour $(\mu R / h r)$. (See Figure 2, page 14.)

2. Weather Monitoring Station - provides current weather data such as air temperature, wind velocity, wind direction, and barometric pressure. (See Figures 3 and 4 , pages 15 and 16. ) 
3. Ambient Air Sampler - continuously pulls air through a filter that traps small airborne particles. The filters are analyzed for the presence of radioactive materials. (See Figure 5, page 17.)

4. Thermoluminescent Dosimeter (TLD) - TLDs contain a luminescent material that is sensitive to penetrating ionizing radiation such as gamma rays. (See Figure 6, page 18.) 


\section{Dudley. Weiland - Station Manager .}

Education: Denver University, BSBA, Business Administration, M.A., Educational Administration Current Teaching Position: 6th Grade at Peck Elementary

Projects: Environmental Activity - Xeriscape Gardens at Peck Elementary

Super C Speaking Group

Arvada Teacher of the Year 1993

Dudley, whose wife Jody also teaches, has six children: Mike, Pauley, Dave, Debbie, Tom, Nikki, twelve grandchildren, and two bearded collies. His interests also include ceramics, biking, grandchildren, and camping.

\section{Shown Yasutake - Alternate....}

Education: Colorado school of Mines, B.S., Geological Engineering

University of Colorado, Certification

Current Teaching Position: Arvada Junior High earth science, math, life science and physical science.

Projects: Worked on developing new curriculum for the 8 th grade physical science program. The program incorporates units in energy and motion, chemistry air pollution, water resources, toxic waste, and laser technology.

Shawn enjoys volleyball, mountain biking, triathlons, swimming, movies, music, trivia, and scuba diving. At the start of the 1994 school year, he will begin teaching at Arvada Senior High.

\section{Station Managers Broomiteld - Emerald Park (EP) Station}

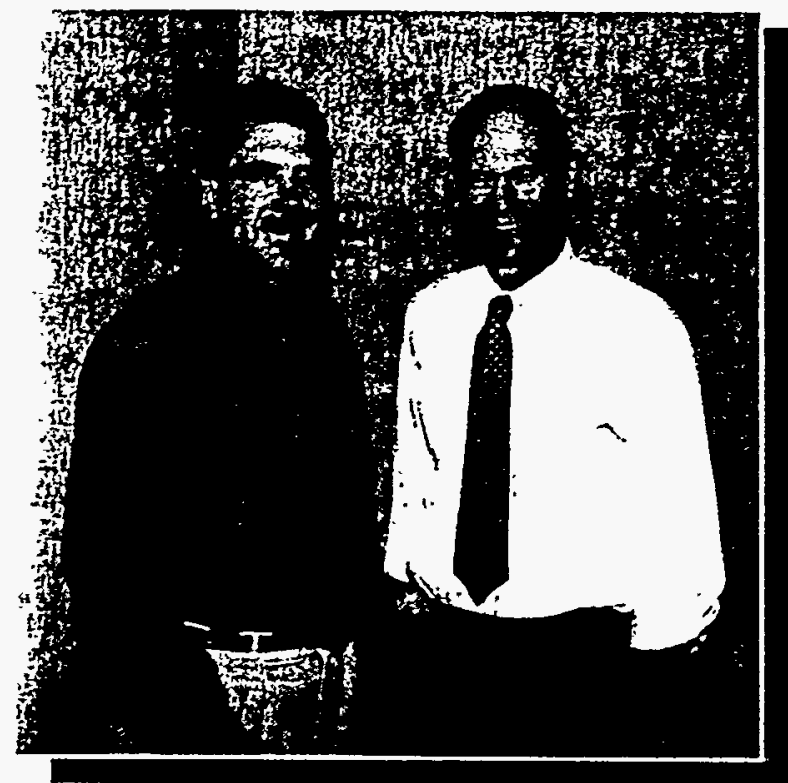

\section{Station Managers}

Standley Lake Library (SLL) Station

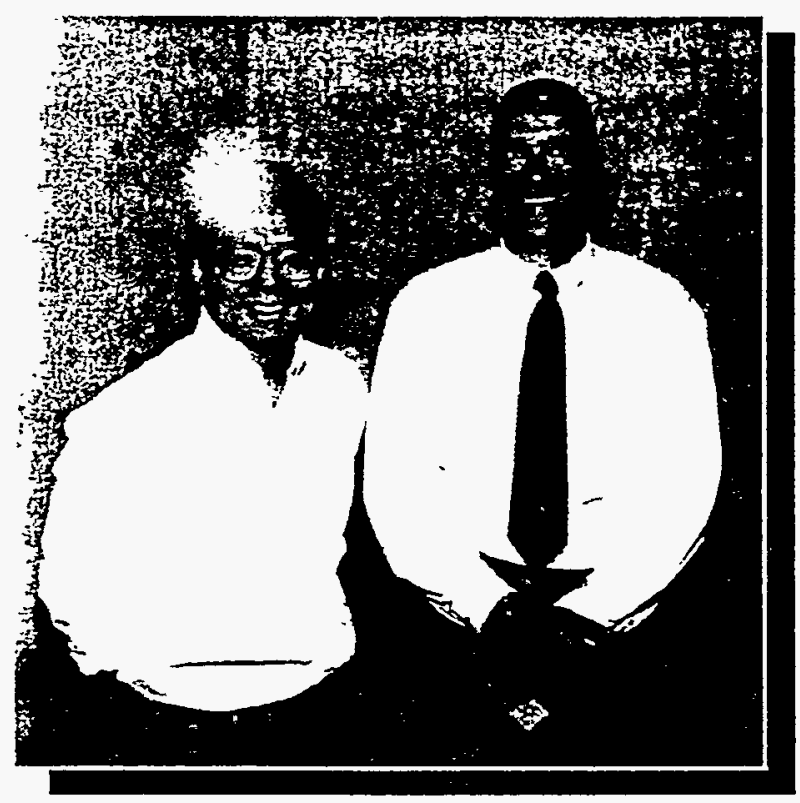

\section{Richard Borinsky - Station Manager}

Education: University of Colorado

B.A., Biology Major, 1988

The Citadel, M.A.T.,

Biology, 1971

\section{Current Teaching Position:}

Broomfield High School - Biology Science

Department Chair

Rich has four dogs, three of which are Chows. His interests are skiing, tennis, bicycling, hiking, and salt water aquariums.

\section{Robert: Morgenstern - - Alternate :}

Education: University of Colorado

B.A., History

Lehman College, New York, M.A., Biology

Current Teaching Position:

Standley Lake High School - Earth Science

Projects: Sponsor of the Ski Club

Bob, whose wife Rosalind also teaches, has a son who is a science teacher, and a daughter who just graduated from Arizona State University. His interest include sports, being outdoors, and traveling. 
Douglas Smith - Station Manager:

Education: Colorado State University, B.S., Biological Science

Current Teaching Position: Northglenn High

School - Cell Biology, Genetics, Ecology

Projects: Sponsor of Riverwatch Team, a project in conjunction with the Colorado Division of Wildlife to monitor water quality of Colorado rivers. Sponsor of Science Superday, an event for students to increase enthusiasm and motivation for science Sponsor "9 Give 'Em Health" Fair.

Doug and his wife, Jo, live in Westminster with their two children, Scott and Kim, one Springer Spaniel, and a cat. He enjoys white water rafting, kayaking, hunting, fishing, skiing, running, and gardening.

\section{Theodore Motsuo-Alternate}

Education: Regis University, B.S., Biology

\section{Current Teaching Position:}

Skyview High School - Physical Science, Chemistry, and Interdisciplinary Science Projects: Newsletter to District

Ted and his wife, Barbara, live in Arvada. Their children Mike, Trevor, and Tamara are grown and out in the world. Ted enjoys fishing and camping, gardening, judo, wood working, and coaching Junior High basketball.
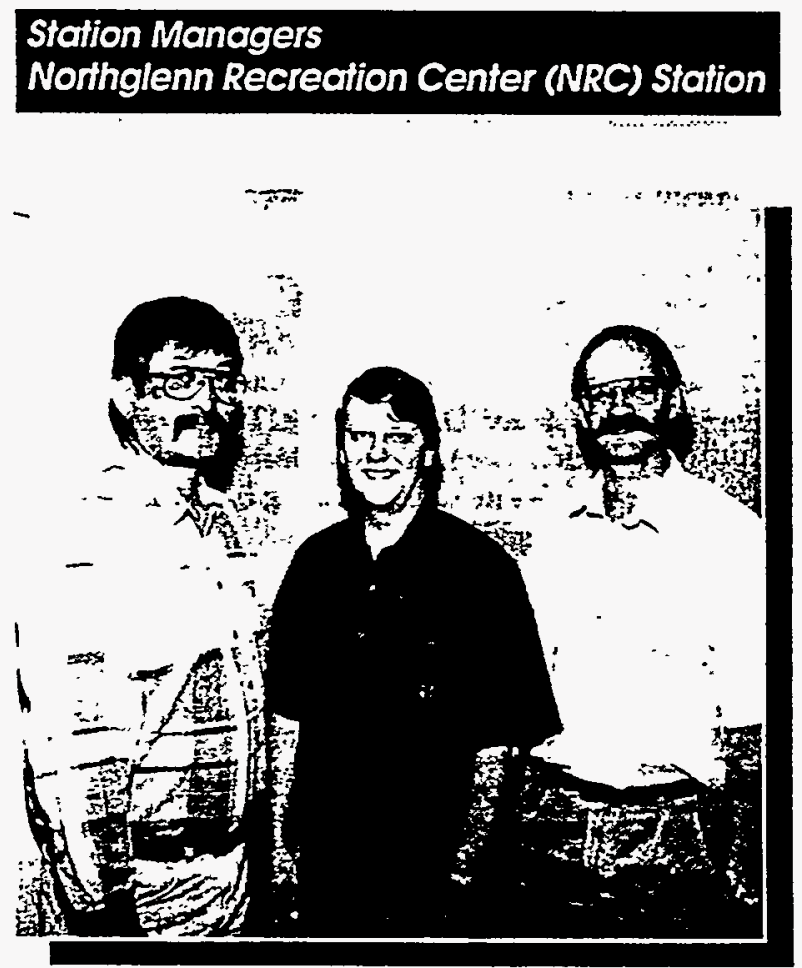
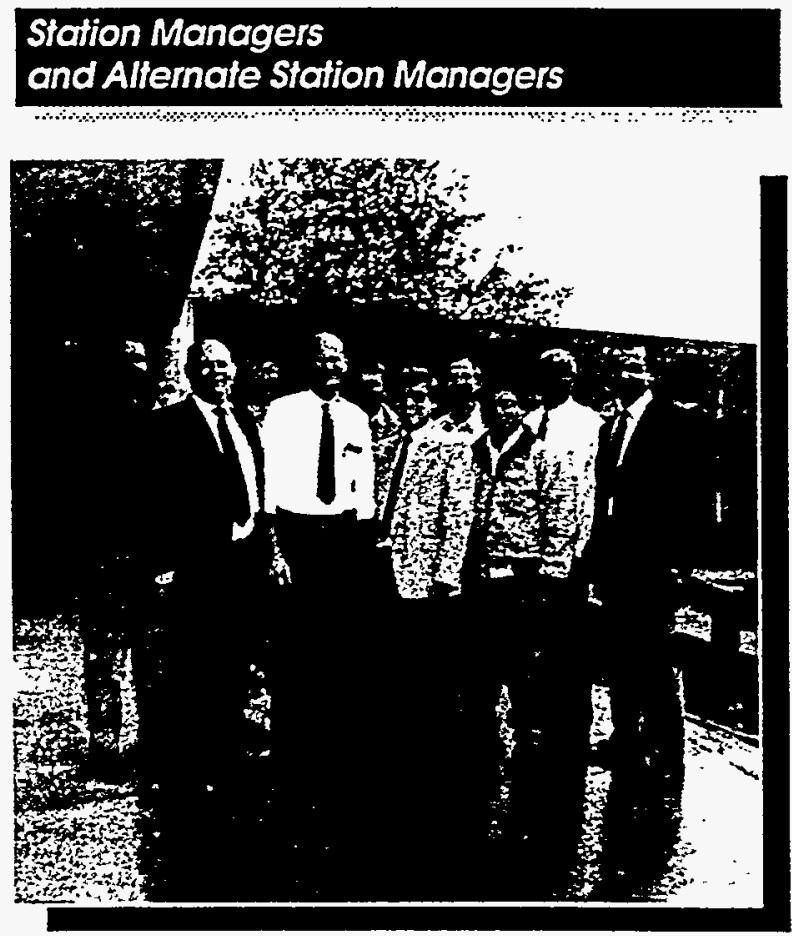


\section{Community Radiation Monitoring Program}

\section{J. Kim Natale- Station Manager}

Education: University of Colorado, B.A., Physics University of Colorado, M.S., Education Cument Teaching Position: Standley Lake High School - Physics, Astronomy, Nuclear and Quantum Physics

Projects: Built a homemade telescope. Helped students build a Tesla coil, map radon throughout the Standley Lake High School, make holograms, and measure radiation.

Kim lives in Arvada with his wife and 4 boys, three of whom are triplets. He also enjoys building furniture in his spare time. He was the 1984 Colorado Teacher of the Year, the Colorado selection for NASA Teacher in the Space Program, 1985 winner of the Arvada "Image" Award, and in 1986 was selected as Arvada "Man of the Year."

Forrest Shoemaker - Alternote

Education: Colorado State University, B.S., Biological Science, University of Mississippi, M.S., Combined Sciences, and Ph.D., Higher Education and Biology

Current Teaching Position: Standley Lake High

School - Biology, Science Department Chair

Projects; Serves on many national science committees, teaches at the Graduate School at the University of Maryland during the summers.

Forrest lives in Arvada with his wife, Virginia, who is a Director of Christian Education at the Arvada Presbyterian Church. He has three children: Tod, an Instructor in Hawaii; Ken, a journalist in Sweden; and Cindy, a graphic artist/illustrator. Forrest was awarded the Presidential Award for Excellence in Science and Math Teaching - National Level. He enjoys gardening, working in the greenhouse, and racquetball.
Station Managers

Countryside Recreational Center (CRC) Station

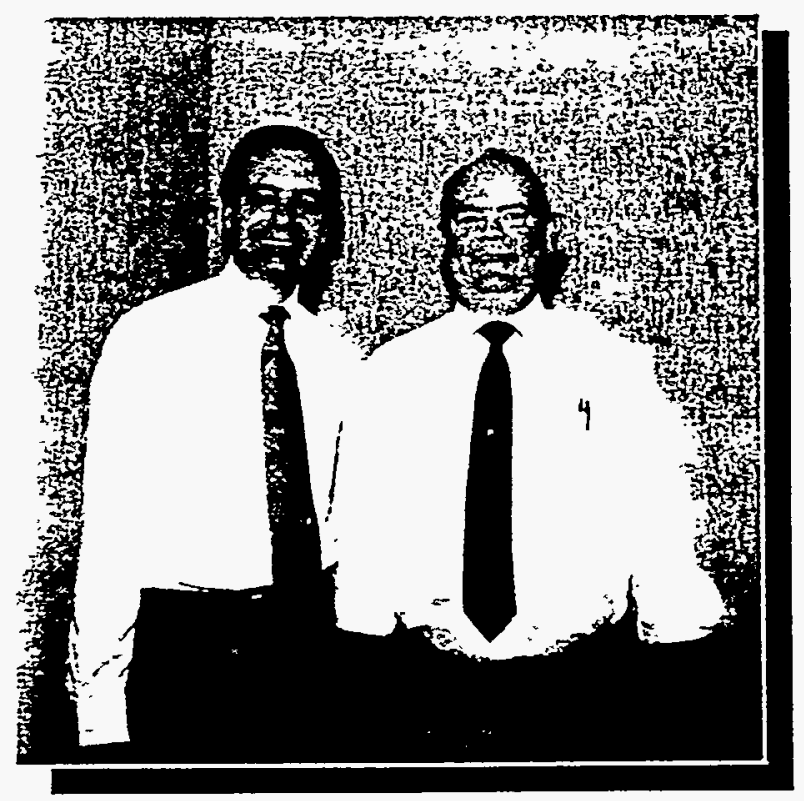




\section{Lonnie Newton - Station Manager}

Education: University of Northern Colorado, B.A., Biological Science, University of Northern Colorado, M.A., Special Education Current Teaching Position: Drake Junior High School, Life Science

Lonnie and his wife, Karen, have two children, Brendon and Courtney. He enjoys fishing, camping, and hunting as well as coaching and officiating at high school volleyball, umpiring at high school and Little League baseball.

William Jones - Alternate Education: Regis College, B.S., Chemistry and Biology, University of Northern Colorado, M.A. University of Colorado, Certification Current Teaching Position: Arvada West High School - Honors Chemistry, Chemistry I, Environmental Technology

Projects: Adult mentors for environmental technology students, Environmental Technology Curriculum Pilot, and training for teachers for this course.

Bill has lived in Arvada for 19 years with his wife, Nora, and their three children, Kevin, Colleen, and Carrie, as well as their dog, Corky. His interests include snow skiing, camping, and fishing.

\section{Station Managers \\ Ralston Recreation Center (RRC) Station}

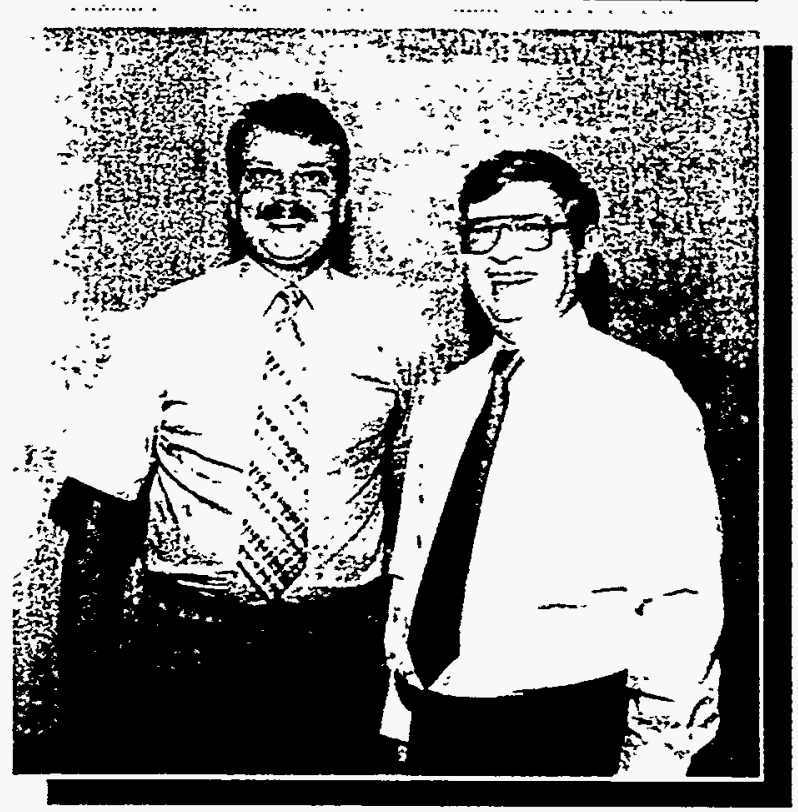




\section{Community Radiation Monitoring Program}

As shown in Table 1, ambient (outdoor) air sampling for the ComRad program at the Standley Lake Library monitoring location. Incomplete laboratory analysis occurred in the March 5 - April 5 and again in May 5 - June 7 sampling period. A picocurie ( $\mathrm{pCi}$ ) is the unit used to measure the amount of radioactive material present; a cubic meter $\left(\mathrm{m}^{3}\right)$ is the unit used to measure the volume of air.

\section{Table 1 \\ Standley Lake Library Ambient Air Monitoring Station Plutonium-239, -240 Concentration}

\section{Sampiling \\ Period}

$02 / 17 / 92 \cdot 03 / 30 / 92$

03/3092-04/27/92

04/27/92 - 05/25/92

$05 / 25 / 92$ - 06/22/92

$06 / 2292$ - 07/20192

$07 / 20192$ - 08/31/92

08/31/92 - 09/28/92

09/28/92 - 10/28/92

10/28/92 - 11/23/92

11/23/92 - 12/21/92

$12 / 21 / 92 \cdot 01 / 04 / 93$

$01 / 04 / 93$ - 02/04/93

$0204 / 93$ - 03/05/93

$03 / 05 / 93-04 / 05 / 93^{3}$

$04 / 05 / 93 \cdot 05 / 05 / 93^{b}$

$05 / 05 / 93$ - 06/07/93"
Filters

in Composite

Sample

\author{
Piutonium \\ Concentration \\ (DCH/m)
}

\author{
+1-95 percent \\ Confidence Interval \\ $\left(\mathrm{pC} / \mathrm{m}^{3}\right)$
}

\footnotetext{
$m^{3}=$ cubic meter

$\mathrm{pCi}=$ picocuries

- Incomplete lab analysis

- Filter misplaced
}

$\begin{array}{ll}0.000000 & 0.0000004 \\ 0.000000 & 0.0000005 \\ 0.000001 & 0.0000060 \\ 0.000003 & 0.0000009 \\ -0.000002 & 0.0000008 \\ 0.000001 & 0.0000007 \\ 0.000000 & 0.0000001 \\ 0.000002 & 0.0000002 \\ 0.000000 & 0.0000001 \\ 0.000000 & 0.0000001 \\ 0.000000 & 0.0000001 \\ 0.000003 & 0.0000001 \\ 0.000001 & 0.0000005\end{array}$

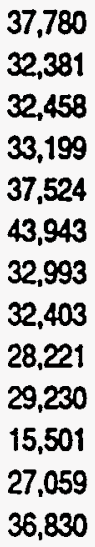

0.0000005 
The weather station addresses the meteorological monitoring activities required to support the ComRad program. Meteorological information is a necessary part of any data collected from an environmental radiation monitoring system. This information is required in the investigation of the variation of the background radiation level.

Table 2 includes meteorological and gamma radiation data for May 7 to June 4, 1993.

\section{Table 2}

\section{Standley Lake Library Weather and Exfernal Gamma Radiation Data}

\begin{tabular}{|c|c|c|c|c|c|c|c|c|}
\hline Dale & $\begin{array}{l}\text { Wind } \\
\text { Chill }\end{array}$ & Rainfale & Iime & $\begin{array}{l}\text { Amblent } \\
\text { Temp. }\end{array}$ & $\begin{array}{l}\text { Barometric } \\
\text { Pressure } \\
\text { (inches) }\end{array}$ & $\begin{array}{l}\text { Wind Direction } \\
\text { Degrees } \\
\text { (from North) }\end{array}$ & $\begin{array}{l}\text { Wind } \\
\text { Speed } \\
\text { (mph) }\end{array}$ & $\begin{array}{c}\text { External } \\
\text { Gamma } \\
\text { HRhr }\end{array}$ \\
\hline $05 / 07 / 93$ & 43 & 0.04 & 3:58 PM & 47 & 29.80 & 32 & 5 & 15.9 \\
\hline $05 / 10 / 93$ & 38 & 0.04 & 6:47 AM & 38 & 30.39 & 176 & 0 & 19.6 \\
\hline $05 / 1293$ & 62 & 0.04 & 4:59 PM & 66 & 30.49 & 90 & 5 & 142 \\
\hline $05 / 14 / 93$ & 53 & 0.04 & $1: 26 \mathrm{PM}$ & 61 & 30.36 & 356 & 17 & 21.5 \\
\hline $05 / 17 / 93$ & 50 & 0.07 & $6: 50 \mathrm{AM}$ & 49 & 30.1 & 175 & 0 & 172 \\
\hline $05 / 19 / 93$ & 62 & 0.31 & 4:08 PM & 62 & 30.46 & 4 & 0 & 16.6 \\
\hline $05 / 21 / 93$ & 69 & 0.33 & 5:52 PM & 69 & 30.16 & 4 & 0 & 21.6 \\
\hline $05 / 24 / 93$ & 42 & 0 & 7:15 AM & 42 & 30.26 & 324 & 3 & 16.0 \\
\hline $05 / 26 / 93$ & 47 & 0.06 & 6:56 AM & 46 & 30.24 & 274 & 1 & 19.6 \\
\hline $05 / 28 / 93$ & 63 & 0.06 & 3:50 PM & 66 & 30.34 & 213 & 4 & 16.6 \\
\hline $05 / 31 / 93$ & 75 & 0.28 & 1:53 PM & 75 & 30.57 & 175 & 2 & 19.6 \\
\hline $06 / 0293$ & 60 & 0 & $11: 53 \mathrm{AM}$ & 61 & 30.23 & 4 & 3 & 19.3 \\
\hline $06 / 04 / 93$ & 48 & 0.21 & 4:30 PM & 53 & 30.2 & 2 & 4 & 16.0 \\
\hline
\end{tabular}

- Accumulated rainfall until reset by Station Manager 
Environmental

Thermoluminescent

Dosimeter

Measurements
The 1992 environmental measurements from TLDs at the Standley Lake Library Monitoring Station are summarized in Table 3. The average quarterly dose equivalents extrapolated for each quarter reported were 110,124, and 146 millirem (mrem) $(1.10,1.24$, and 1.46 millisieverts [mSv]). These values are similar to those reported by the National Council on Radiation Protection and Measurements (NCRP) for background gamma radiation in the Denver area. The NCRP reports an annual range of 125 - 190 mrem $(1.25-1.90 \mathrm{mSV})$.

- TLD dose is a measure of penetrating ionizing radiation typically originating from gamma radiation sources and cosmic radiation.

Table 3

Environmental Thermoluminescent Dosimeter Measurements
Lecegtions

Standley Lake

Liorary

\author{
Dose Equivalent \\ For Second \\ Quarter (mrem)
}

$0406 / 92-07 / 2292$
Dose Equivalent

For Third

Quarter (mrem)

07/2292 - 10/16/92

124
Dose Equivalent

For Fourth

Guarter (mrem)

$10 / 1692-01 / 2293$
110

$01 / 22 / 92-04 / 06 / 92$

NA

$-124$

146 
Each ComRad site employs a station manager and an alternate station manager. The managers are local science teachers who are responsible for operating the equipment, collecting samples, preparing and submitting the samples to a designated laboratory, and providing a detailed summary of the results to the public.

The station managers have completed 80 hours of training on radiation concepts, dose assessment, instrumentation, community and media relations, meteorology, atmospheric dispersion, and air monitoring history of the RFP. Technical experts from Environmental Management, Facilities Engineering, Radiation Detection Systems, Community and Media Relations, and DOE participated in this training.

\section{Station Managers and Alternate Station Managers}

Arvada: Ralston Recreation Center

Station Manager Alternate Station Manager
Lonnie S. Newton

William J. Jones
429-9142

423-0906

Arvada: Standley Lake Library

$\begin{array}{lll}\text { Station Manager } & \text { Dudley L. Weiland } & 442-9260 \\ \text { Alternate Station Manager } & \text { Shawn M. Yasutake } & 467-3864\end{array}$

Broomfield: Emerald Park

Station Manager $\quad$ Richard M. Borinsky 438-0801

Alternate Station Manager $\quad$ Robert D. Morgenstern 460-1131

Northglenn/Thornton:

Northglenn Recreation Center Complex

Station Manager

Alternate Station Manager
Douglas S. Smith

Theodore T. Matsuo
466-3889

940-9943

Westminster: Countryside Recreational Center

Station Manager

Alternate Station Manager
James K. Natale

Forrest H. Shoemaker
423-7922

427-2898 


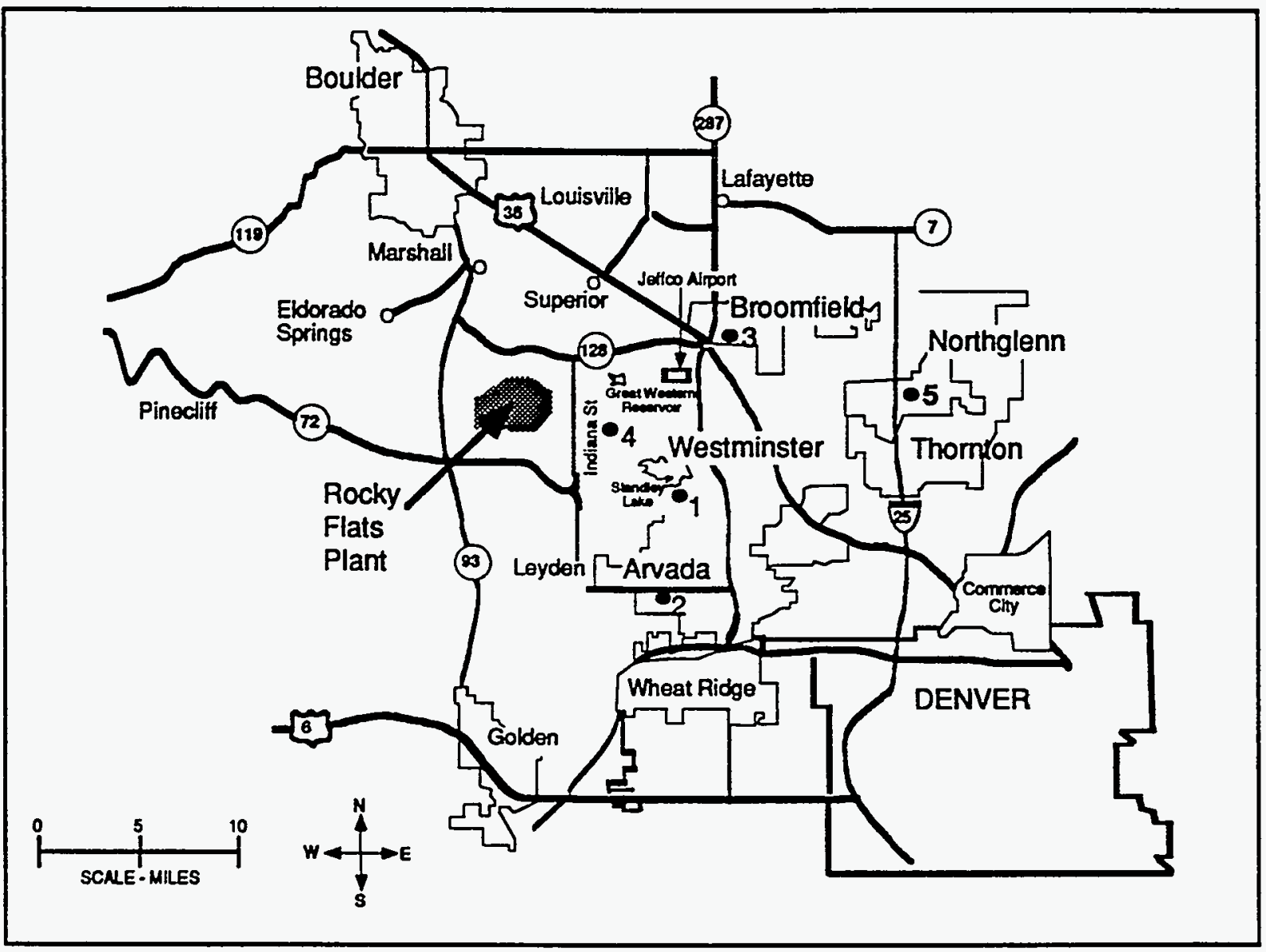

-1. Arvada - Standley Lake Library - 8485 Kipling

-2. Arvada - Ralston Recreation Center - 6300 Simms Street

-3. Broomfield - Emerald Park - 295 Main Street

-4. Westminster - Countryside Recreation Center - 10470 Oak Street

-5. Northglenn/Thornton - Northglenn Recreation Center 11701 Community Center Drive

Figure 1. Monitoring Station Locotions 


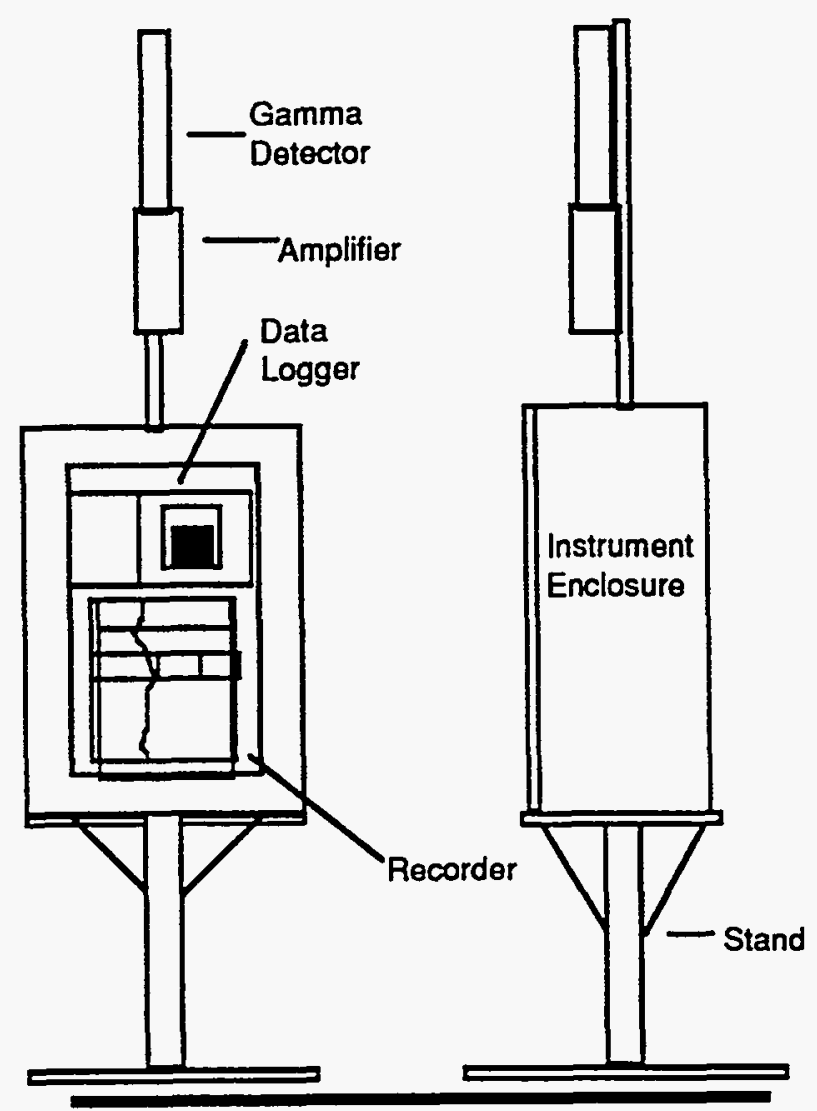

- The natural background gamma radiation range in Colorado is approximately $10-30 \mu \mathrm{R} / \mathrm{hr}$.

- In Colorado, gamma radiation from the earth is higher than the United States average because of naturally occurring thorium, uranium, and radon in the soils and rocks.

- In Colorado, gamma radiation from space is higher than the United States average because of Colorado's higher altitude and reduced shielding of cosmic radiation by the atmosphere.

- A micro-roentgen is one-millionth of a roentgen, which is a unit that tells the amount of energy transferred from a radiation source to a unit of air. It is a measure of the amount of ionization that takes place in a unit of air and applies only to radiation from gamma photons and $x$-rays.

- The detector does not emit radiation, it only detects radiation.

Figure 2. Gamma Radiation Detector 


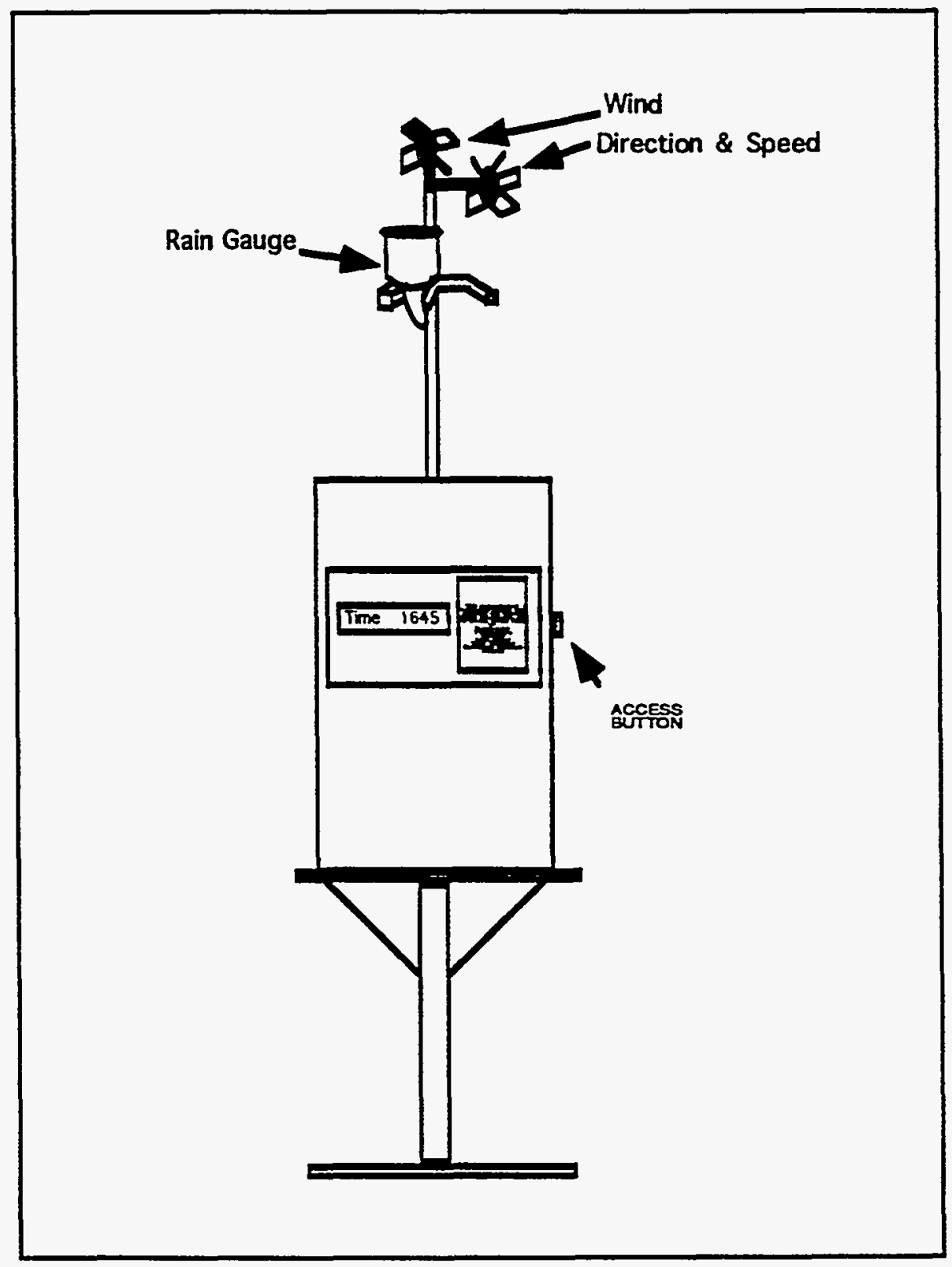

- Weather station displays current conditions that sometimes can affect background radiation.

- The weather station panel is enlarged and shown in detail on page 16.

Figure 3. Weather Station 


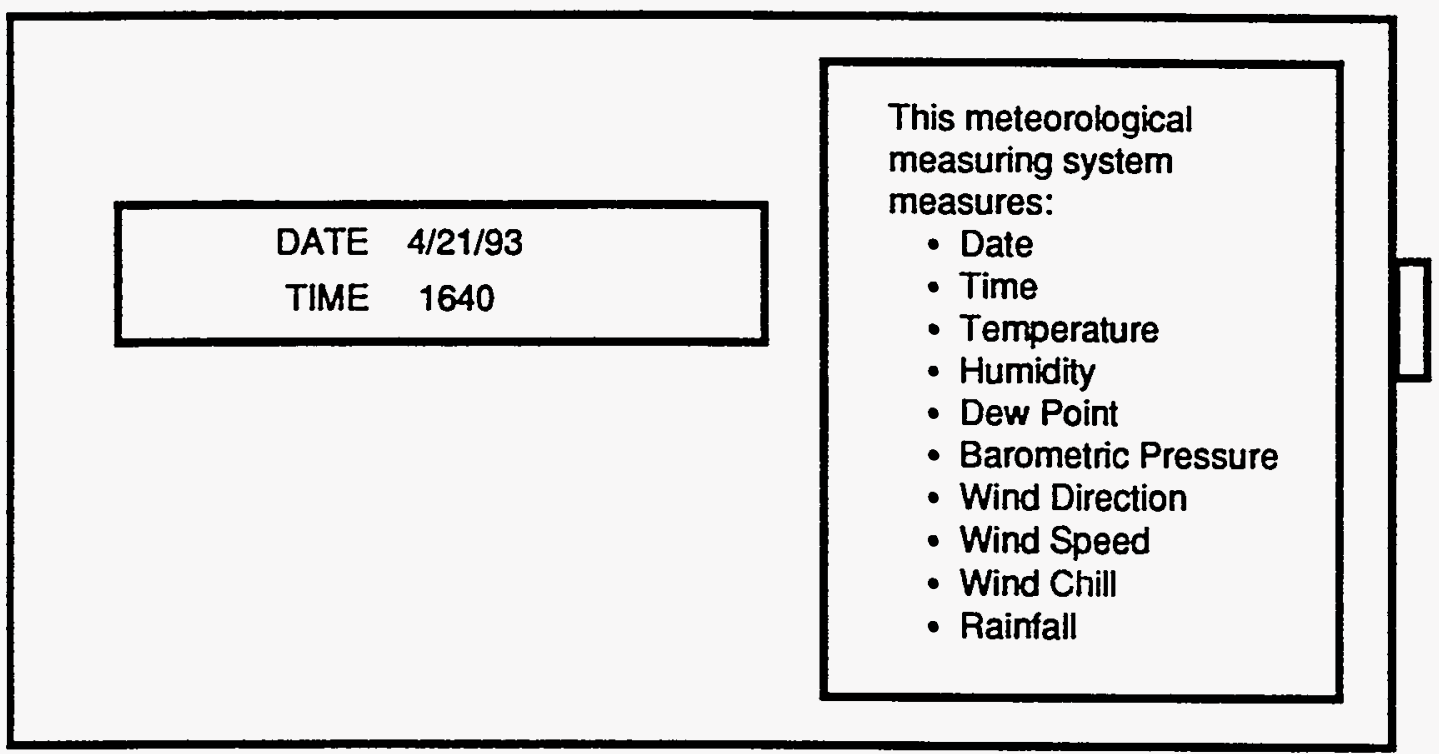

- TIME - The current time in 24-hour time

- DATE - Current month, day, and year

- TEMPERATURE - Measures hotness and coldness of surrounding air

- HUMIDITY - The amount of water vapor in the air

- DEW POINT - Temperature at which dew starts to form or vapor condenses into liquid

- BAROMETRIC PRESSURE - Measures the atmospheric pressure

- WIND DIRECTION - Measures direction from which wind blows in degrees of circle $\mathrm{N}=360$, $S=180, E=90, W=270$

- WIND SPEED - Measured in miles per hour

- WIND CHILL - Temperature of windless air that would have the same effect on exposed skin as a given combination of wind speed and air temperature

- RAINFALL - The amount of rain collected over a specific time

Figure 4. Weather Station Panel 


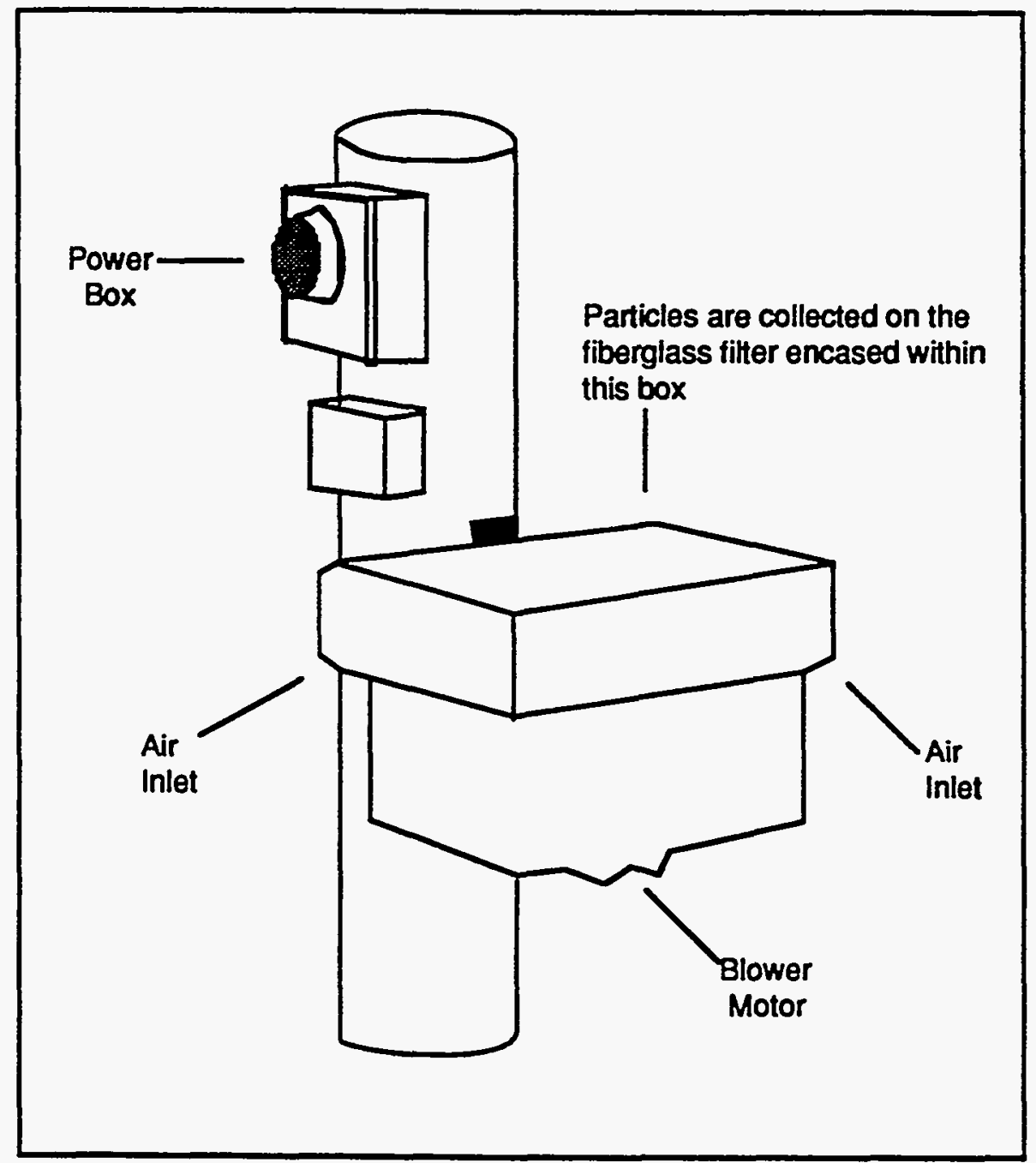

- The sampler operates continuously at a rate of approximately 12 liters per second (1/s) (25 cubic feet per minute $[\mathrm{cm}])$.

- Air particulates are collected on an $8^{\prime \prime} \times 10^{\prime \prime}$ fiberglass filter. Filter test specifications rate this filter to be 99.97 percent efficient for relevant particle sizes.

- Filters are changed once every 4 weeks.

- Filters are analyzed monthly for plutonium.

Figure 5. Ambient Air Sompler 


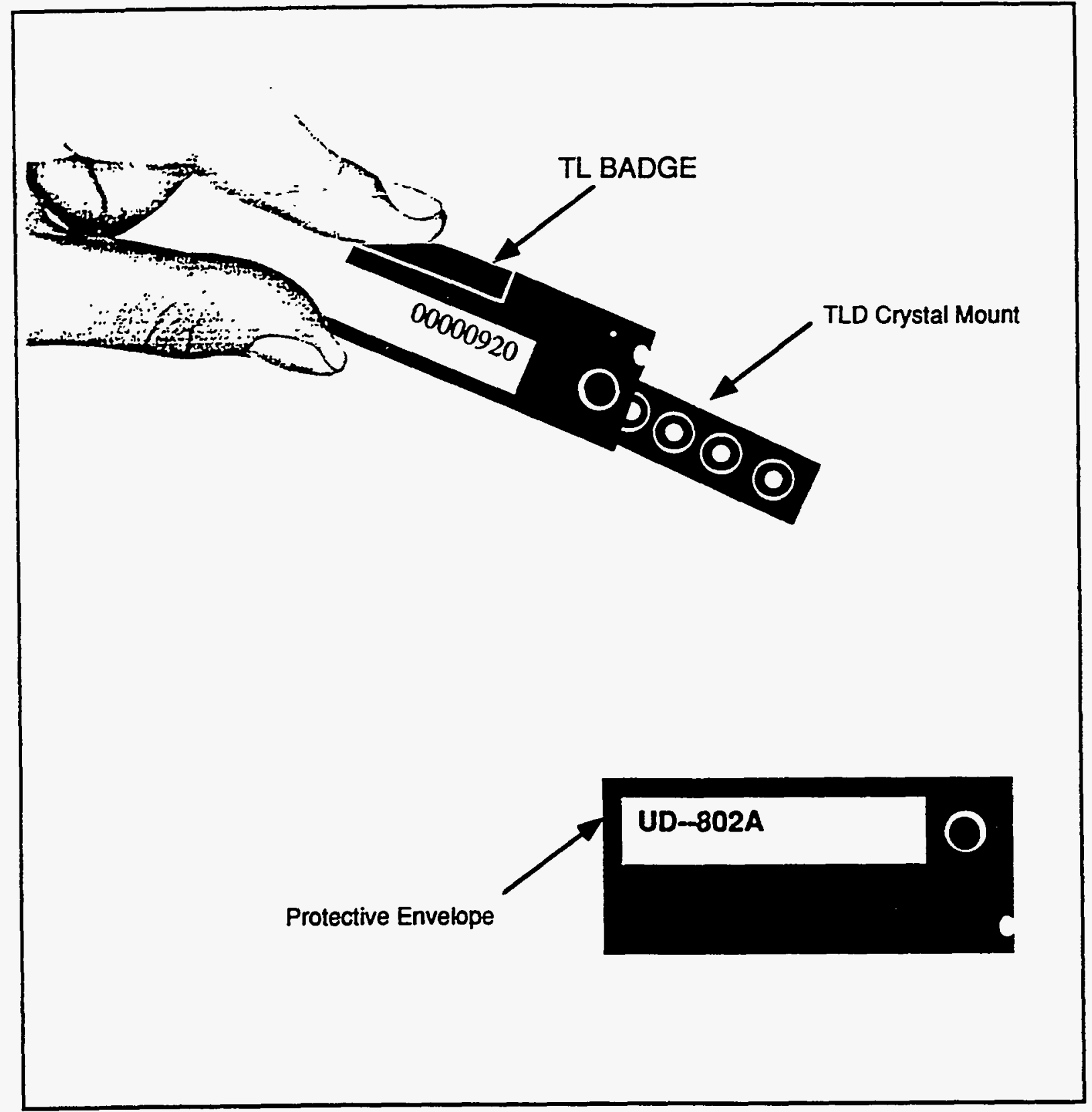

Figure 6. Thermoluminescent Dosimeter 
Absorbed Dose - The amount of radiation energy deposited per unit mass of any material. The traditional unit of measurement of absorbed dose is the rad. The International Standard (SI) unit of measurement of absorbed dose is the gray (GY); $1 G Y=100$ rads.

Alpha Particle - A positively charged particle emitted from the nucleus of an atom having the same charge and mass as that of a helium nucleus ( 2 protons, 2 neutrons). Alpha particles are nonpenetrating radiation and can be stopped by a piece of paper or the outer dead-cell layer of the skin. They are potentially harmful only if the source of the particles (the radioactive material itself) is inside the body in direct contact with living tissue.

Americium (Am) - A white metallic transuranic element of the actinide series, having isotopes with mass numbers from 237 to 246 and half-lives from 25 minutes to 7,950 years. The isotope americium-241 is a radioactive decay product of plutonium-241 and has been separated from plutonium in some RFP activities.

Atom - The smallest unit into which an element can be divided and still retain the properties of the element. Atoms consist of two main parts: the nucleus containing protons and, usually, neutrons and the electron cloud.

Becquerel (Bq) - The SI unit used to quantify the amount of radioactive material based on its rate of radioactive decay. One becquerel of any radioactive material is equal to 1 radioactive disintegration per second.

Beta Particle - A negatively charged particle emitted from the nucleus of an atom having the same mass and charge as an electron. Beta particles are moderately penetrating, depending on their energy. External sources of beta particles may be potential hazards to skin tissue or the lens of the eyes, if the source is close enough to the tissue.

Collective Dose - The sum of all doses received, or estimated to be received, by a population. The traditional unit of collective dose is the person-rem. The SI unit is the person-sievert. For example, a dose of $1 \mathrm{rem}(0.01 \mathrm{~Sv})$ to 10 people would result in a collective dose of 10 person-rem ( 0.1 person-Sv).

Contaminant - An undesired radioactive and/or toxic substance in an area where it can cause exposure to personnel, loss of equipment, or a release to the environment. 
Counts per minute (Cpm) - A unit that indicates the response of a radiation detection or measuring instrument.

Criticality - A nuclear chain reaction that can result in the release of ionizing radiation such as neutrons, beta particles, gamma, and $x$-rays. When close to the criticality, radiation intensities and resulting doses may be very high.

Curie (Ci) - The traditional unit used to quantify the amount of radioactive material based on its rate of radioactive decay. One curie of any radioactive material is equal to $3.7 \times 10^{10}$ radioactive disintegrations per second.

$$
\begin{aligned}
& \text { Picocurie (pCi) }-10^{-12} \mathrm{C} \text {, } \\
& \text { one-trillionth of a curie; } \\
& 3.7 \times 10^{-2} \text { disintegrations } \\
& \text { per second (dps). }
\end{aligned}
$$

Dose equivalent - The absorbed dose in rads multiplied by a quality factor which accounts for the different biological effect of different types (e.g., alpha, beta, gamma, $x$-ray) of ionizing radiation. Dose equivalent allows comparison of the biological effect of different types of ionizing radiation when the same tissue is exposed. The traditional unit of dose equivalent is the rem. The SI unit is the sievert (Sv). $1 \mathrm{~Sv}=100 \mathrm{rem}$;

1 rem $=1,000$ millirem (mrem).

Disintegrations per minute (Dpm) - A unit that indicates the rate of radioactive decay of a radioactive material.

Effective Dose Equivalent (EDE) - The sum of the risk-weighted dose equivalents to the organs of the body receiving significant ionizing radiation exposure. The risk-weighting factors are based on the risk of cancer mortality and serious genetic effects. Use of EDE allows a direct comparison of risk from any types of ionizing radiation to any tissues of the body. One rem EDE from natural background radiation has the same risk as one rem EDE of artificially produced radiation. The traditional unit of $\mathrm{EDE}$ is the rem. $1 \mathrm{rem}=1,000$ millirem (mrem). The International Standard unit of EDE is the sievert. $100 \mathrm{rem}=1 \mathrm{~Sv}$.

Electron Cloud - One of the two main parts of an atom, consisting of a number of electrons in motion around the nucleus. Each electron has its own negative $(-1)$ charge. The number of electrons in the electron cloud is equal to the number of protons in the nucleus. 


\section{Community Radiation Moniforing Program}

Environmental Air Samples - Air samples taken at specified locations of interest to monitor the air.

Exposure - In terms of electromagnetic ionizing radiation, the amount of ionization produced by gamma or $x$-ray radiation per volume of air. The traditional unit of exposure is the roentgen (R).

External Source - A source of radiation that is located outside of the potentially exposed body. Radiation from external sources must have sufficient energy to reach living tissue before it can cause damage to the tissue.

Extrapolate - To make an estimate or prediction of unknown data on the basis of available data.

Gamma Photon - Electromagnetic radiation emitted from the nucleus of an atom during radioactive decay. Gamma photons often have high energy and are highly penetrating.

Electromagnetic radiation has no mass and no charge and must cause ionization of material through indirect means.

Half-Life - The amount of time required for one half of the original number of atoms of a radionuclide to undergo radioactive decay. For example, the half life of uranium-238 is about 4.5 billion years.

Inhalation - To take a substance into the body by breathing through either the nose or mouth.

Internal Source - A source of radiation that is located inside the body and therefore in close or direct contact with some living tissue. Even nonpenetrating types of radiation (e.g., alpha particles and low-energy beta particles) can cause damage to tissue when emitted from internal sources of radioactive material.

Ion - A positively or negatively charged atom. The change occurs when the number of electrons does not match the number of protons.

Ionization - The production of ions usually through the addition or release of electrons.

Ionizing Radiation - Radiation of sufficiently high energy to be capable of causing ionization and excitation of material. It is through this ionization and excitation that ionizing radiation has its effects, including damage to biological tissue. 
Isotope - Atoms of one element (that is, with the same number of protons) with different numbers of neutrons. For example, uranium-235 and uranium-238 are isotopes of uranium.

Natural Radiation - Radiation arising from cosmic sources and from naturally occurring radionuclides (such as uranium or radon) present in the human environment.

Neutron - A constituent of the nucleus of an atom that has no charge and has a mass approximately equal to that of a proton. When emitted from the nucleus, neutrons are a type of ionizing radiation that can be highly penetrating, depending on the energy of the neutron.

Particulate - A small quantity or fragment of a substance that can be small enough to become airborne.

Pathway - Potential route for exposure to radioactive or hazardous materials. Usually expressed in terms of air, surface water, groundwater, soils, etc., for inhalation or ingestion.

Penetrating Radiation - Radiation that can travel relatively long distances and can penetrate the body, depositing some of its energy, and then continue at a lower energy. Examples are gamma (photons), $x$-rays, and neutrons. Penetrating radiation can interact with and damage tissue even when the source of radiation is outside the body.

Person-rem - The traditional unit of collective dose to a population. (See "Collective Dose.")

Plutonium (Pu) - A naturally radioactive, silvery, metallic transuranic element, occurring in uranium ores and produced artificially by neutron bombardment of uranium, having 15 isotopes with masses ranging from 232 to 246 , and half-lives from 20 minutes to 76 million years. Isotopes of plutonium handled at RFP include plutonium-238 -239, -240, -241, and -242 .

Progeny - The decay products of the radioactive decay of a radionuclide. These products may themselves be radioactive and result in further decay and progeny. For example, radium-226 has successive radioactive progeny until the decay chain ultimately ends with nonradioactive lead.

Proton - One of the three primary subatomic components found in the nucleus of an atom. Protons are positively $(+1)$ charged particles. 
Rad - The traditional unit of absorbed dose (energy) per unit mass of any material, such as human tissue. When using this term, the type of radiation and the absorbing material must be specified. (See "Absorbed Dose.") The SI of units of absorbed dose is the gray (GY) (1 GY $=100$ rads).

Radioactivity - The spontaneous disintegration of an unstable nucleus of an atom, with the resulting emission of some form (or forms) of ionizing radiation. Common types of ionizing radiation emitted include alpha, beta particles, gamma, and $x$-rays.

Radioactive Decay - The process of disintegration of an unstable, radioactive nucleus. (See "Radioactivity.")

Radionuclide - A radioactive element characterized by the constitution of its nucleus. The nuclear constitution is specified by the number of protons, number of neutrons, and energy content; or, alternatively, by the atomic number (protons), mass number (protons + neutrons), and atomic mass.

Radon (Rn) - A radioactive element of atomic number 86. Radon-222 is an isotope of radon that results from the radioactive decay chain of naturally occurring uranium-238. It is an inert gas having some radioactive progeny that represent a potential radiation dose hazard when inhaled.

Range of a Radiation Detector - The span of the response over which a radiation detector will operate. For example, some portable survey meters have multiple ranges of from $0-50 \mathrm{cpm}$, $0-500 \mathrm{cpm}$, and $0-5 \mathrm{~K}(5000) \mathrm{cpm}$.

Rem - The traditional unit of dose equivalence; a unit of biological dose that expresses biological damage (that caused by different types of ionizing radiation) on a common scale. (See "Dose Equivalent.")

Roentgen (R) - (rent'gen) The unit that reflects the amount of energy transferred from a radiation source (more specifically its photons) to a unit mass of air. It is a measure of the amount of ionization that takes place in the unit of air and applies only to gamma photons and $x$-ray radiation.

Source Material - Any physical or chemical form of uranium and/or thorium that contain by weight 0.05 percent or more of uranium and/or thorium. A source material is used for calibration or analytical purposes. 
Specific Activity - The amount of radioactivity per mass of a radionuclide. In traditional units, the specific activity is expressed in terms of curies per gram $(\mathrm{Ci} / \mathrm{g})$; in the SI units, it would be expressed in terms of becquerels per kilogram $(\mathrm{Bq} / \mathrm{kg})$.

Thermoluminescent Dosimeter (TLD) - A monitoring device used to measure external sources (i.e., outside the body) of penetrating radiation such as $\mathbf{x}$-rays or gamma rays.

Transuranic Element - An element above uranium in the periodic table; i.e., with an atomic number greater than 92.

Tritium (H-3) - The radioactive isotope of hydrogen having one proton and two neutrons in its nucleus.

Uncontrolled Area - Any area to which access is not controlled for the purpose of protecting individuals from exposure to radiation and radioactive materials.

Uranium (U) - A heavy, silvery-white metallic element that is radioactive, easily oxidized, and has 14 known isotopes of which uranium-238 is the most abundant in nature.

Working level meter (WL Meter) - A meter used to measure the radon progeny in the air in units of working levels. One working level is any combination of polonium-218, lead-214, bismuth-214, and polonium-214 (the short-lived progeny of radon) in 1 liter of air, under ambient temperature and pressure, that results in the ultimate emission of $1.3 \times 10^{5} \mathrm{MeV}$ of alpha-particle energy. This is about the total amount of energy released over a long period of time by the short-lived progeny in equilibrium with $100 \mathrm{pCi}$ of radon.

Worldwide Fallout - Radioactive debris from atmospheric weapons testing that is either airborne and cycling around the earth or has been deposited on the earth's surface.

X-Rays - Electromagnetic radiation released during radioactive decay or produced in radiation-producing equipment. $X$-rays are identical in nature to gamma photons but typically have lower average energies and are not as penetrating. $X$-rays originate from the electron cloud, but can be indirectly produced during radioactive decay. 
Appendix A

Distribution

Eederalagencies

US DOE, RFO

Attn: E. A. Howard

Bldg. 116

Community Technical

Representatives

City of Arvada

Utilities Division

Attn: M. Mauro

8101 Ralston Road

Arvada, CO 80002

City of Broomfield

Attn: K. Schnoor

\#6 Garden Office Center

P.O. Box 1415

Broomfield, CO 80038-1415

City of Northglenn

Attn: K. Scott

2350 W. 112th Avenue

Northglenn, CO 80234

City of Thornton

Attn: B. Hart

9505 Civic Center Drive

Denver, CO 80229

City of Westminster

Attn: D. Cross

13150 North Huron

Westminster, CO 80234

Jefferson County

Attorney's Office

Attn: J. Jacobus

1700 Arapahoe Street

Golden, CO 80419
Health Depaitments

Colorado Department of Health 4300 Cherry Creek Dr., South

Denver, CO 80222-1530

\section{EG\&G ROCKY Flots}

RFP Public Reading Room

c/o Front Range

Community College

3645 W. 112th Avenue

Westminster, CO 80037

D. A. Cirrincione,

Environmental Protection \&

Waste Reporting

T. G. Hedahl, Assistant General Manager, Environmental and

Waste Management

R. C. Nininger, Manager,

Air Quality Division

B. J. Pauley, Air Quality Division

C. M. Sanda, Community

Relations

G. H. Setlock, Director, Environmental Protection Management

Other

Standley Lake Library

8485 Kipling

Arvada, CO 80005

\section{Station Manacers}

R. M. Borinsky 13004 Lowell Court Broomfield, CO 80020

W. J. Jones

10986 W. 77th Avenue Arvada, CO 80005

T. T. Matsuo

11746 W. 74th Way

Arvada, CO 80005

R. D. Morgenstern 3213 W. 133rd Avenue Broomfield, CO 80020

J. K. Natale 11767 W. 74th Way Arvada, CO 80005

L. S. Newton 5993 W. 75th Avenue Arvada, CO 80003

F. H. Shoemaker 13631 W. 54th Avenue Arvada, CO 80002 


\section{DISTRIBUTION LIST}

Nevada Operations Office

U.S. Department of Energy

Las Vegas, Nevada

J.C. Burrows (3)

B.W. Church (4)

M.A. Marelli

DOE/NV Technical Information

Resource Center (2)

J. Ledbetter

Lawrence Livermore National

Laboratory

Mercury, Nevada

W.B. McKinnis

Sandia National Laboratories

Albuquerque, New Mexico \#9311

Albert J. Chabai

U.S. Environmental Protection

Agency

Environmental Monitoring Systems

Laboratory

Las Vegas, Nevada

W.N. Marchant

P.J. Weeden

A. Mullen (5)

U.S. Department of Energy

Washington, D.C.

Office of Public Affairs (2)

Los Alamos National Laboratory

Los Alamos, New Mexico

Library (4)
Lawrence Livermore National

Laboratory

Livermore, California

Technical Information Library

Division (2)

Sandia National Laboratoies

Mercury, Nevada

Library (2)

Desert Research Institute

Reno, Nevada

Dale F. Schulke (2)

Marjory Jones

NOAA/WSNSO

Las Vegas, Nevada

J. Mark Fair

Desert Research Institute

Station Managers:

Managers and Alternates

(2 each)

University of Utah

Gary Sandquist (5)

Desert Research Institute

Las Vegas, Nevada

R.L. Jacobson (2)

Library

Reynolds Electrical \& Engineering

Co., Inc./Coordination \& Information Center

Martha DeMarre

Dr. Stuart Black (1) MS 412 